Charles E. Vawter and Representations of Progressive Education

\author{
A Dissertation \\ Presented to \\ The Faculty of the Curry School of Education \\ University of Virginia \\ In Partial Fulfillment \\ of the Requirements for the Degree \\ Doctor of Philosophy
}

by

Hugh A. Meagher

B.A., M.A.

August 2017 


\title{
Charles E. Vawter and Representations of Progressive Education
}

\author{
by \\ HUGH ALEXANDER MEAGHER \\ (Under the Direction of Derrick P. Alridge)
}

\begin{abstract}
Charles Erastus Vawter, who in the late nineteenth and early twentieth century served as the Superintendent of the Miller Manual Labor School of Albemarle and the Rector of the Board of Visitors at both Virginia Polytechnic Institute and the Virginia State University, was an important progressive educator whose influence is profound but who remains largely forgotten in the early twentieth-first century. After serving as an officer in the Confederate Army's "Stonewall Brigade", Vawter completed his undergraduate education at Emory and Henry College and received his master's degree in mathematics from the University of Virginia. Vawter then devoted the remaining thirty-six years of his life to the education of young Virginians - most of whom came from very humble backgrounds. Despite his prominent role at Miller Manual, Virginia Tech, and Virginia State University, a comprehensive study of Vawter's educational thought has not been attempted prior to this study.

This study seeks to describe and clarify Vawter's educational thought, concentrating on his twenty-seven-year tenure as the superintendent of the Miller School of Albemarle, his fourteen-year service as Rector on the Virginia Polytechnic Board, and his four-year tenure as Rector of the Virginia State University Board, which terminated with Vawter's death in 1905. The study clarifies the ways in which Vawter's upbringing in rural western Virginia, manual training study at the College of Emory and Henry, service in the Confederate Army, and his deep Christian faith shaped his educational philosophy. This study uses historical research methods as a vehicle to place in context Vawter's life experiences and how these experiences shaped his educational methodology. Furthermore, Vawter's educational opinions are noteworthy as
\end{abstract}


American educators struggle to replace the current system of high stakes testing with a system that teaches higher-level thinking.

INDEX WORDS: Charles E. Vawter; Miller School of Albemarle; Virginia Public Universities; Progressive Education; Manual Training Education; Industrial Training; Christianity; Individual Worth 


\section{TABLE OF CONTENTS}

CHAPTER

Page

1 INTRODUCTION

Why Charles Vawter? ................................................................

Research Questions ................................................................6

Relevant Literature.................................................................

Liberal vs Industrial Education ...................................................16

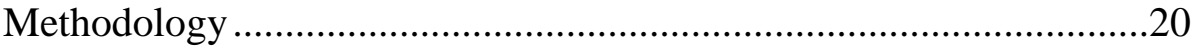

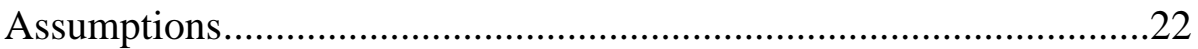

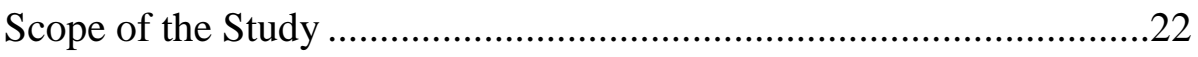

Limitations of the Study..........................................................23

Organization of the Study ........................................................23

2 THE PURPOSES OF PROGRESSIVE EDUCATION .................................24

The Unifying Beliefs of Progressive Education .............................27

The Practice of Experiential Education .........................................29

The Development of an Integrated Curriculum ...............................30

The School as a Welcoming Place ...................................................32

Pragmatism as a Controlling Principle ..............................................33

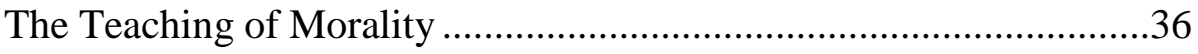

The Teaching of Social Responsibility ..........................................37

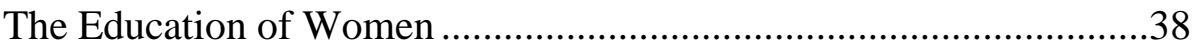


Scientific Racism

The White Architects of Black Education .......................................44

Armstrong and Hampton Institute .................................................45

Washington and Tuskegee Institute ...........................................48

The Washington Du Bois Conflict.................................................50

Virginia State University and Vawter's Work with African Americans ........................51

Political Infighting in Virginia.....................................................53

The White Architects Move to Emasculate Virginia State..................55

The Petersburg College is Renamed

Virginia Normal and Industrial Institute ..............................58

Vawter's Appointment as Rector of the Virginia State Board ............58

Vawter Ignores the Mandate of the White Architects ........................59

4 VAWTER ON INDUSTRIAL VS. LIBERAL EDUCATION .......................62

Industrial Education .............................................................64

Arguments for Liberal Education ...........................................67

Manual Training Education ..........................................................69

The Foundations of Manual Training - the English Inventors ............71

The Role of Women in Manual Training.........................................72

Man is an Animal That Uses Tools..................................................73

Pestalozzi's Role in Manual Training ..............................................74

Manual Training Schools in Russia and the United States .................75 
Manual Training Develops at MIT .76

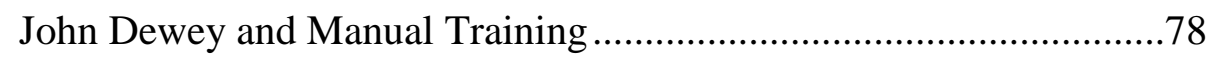

Manual Training in St. Louis ...............................................................

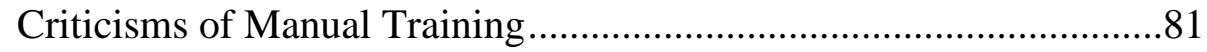

The Decline of Manual Training............................................................ 84

\section{THE BUILDING OF INSTITUTIONS:}

VAWTER AT MILLER MANUAL AND VIRGINIA TECH ....................87

Historical Context: Samuel Miller's Life and Work..............................88

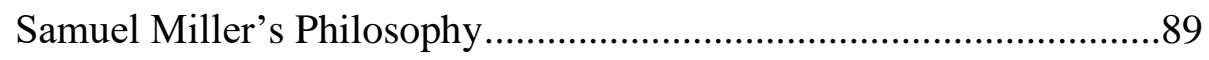

The Construction of the School ...........................................................92

How Vawter Influenced the Program .................................................93

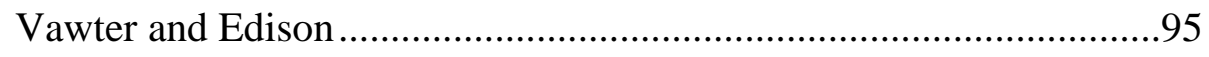

The Establishment of Crozet and Western

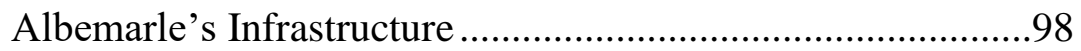

The Miller Manual Labor School Curriculum .......................................99

Vawter's Work at Virginia's Public Colleges ....................................102

The Morrill Act and the Establishment of Virginia Tech ...................103

William Ruffner's Role in the Establishment of Virginia Tech .........104

Vawter's Work at Virginia Tech.......................................................106

Vawter's Role in Strengthening the Academic Program at Virginia Tech ....................................................................108

Vawter's Views on the Virginia System of Education .......................109

Vawter as Rector of the Virginia Tech Board of Visitors ..................111

The Selection of President John McBryde..........................................115 
Faculty Members Charge Vawter with Malfeasance

McBryde and Vawter Reorganize the Virginia Tech

Academic Program...............................................................119

Vawter's Role in the Renaming of the Blacksburg College

6 RECONSIDERING PROGRESSIVE EDUCATION IN OUR TIME

Racial Discrimination in Our Era 125

Liberal vs. Industrial Education in Our Era .....................................129

The Changing Pedagogy of the Twenty-First Century .....................134

The Flipped Classroom .................................................................. 135

The Future of High Stakes Testing

Conclusion 140

SELECTED BIBLIOGRAPHY 142 


\section{Chapter 1}

\section{Introduction}

This dissertation is a study of the progressive work and educational thought of Charles E. Vawter. Vawter was a well-renowned Virginia educator in his roles as the first superintendent of the Miller School of Albemarle ${ }^{1}$ and chairman of the board at both the Virginia Agricultural and Mechanical College (later renamed Virginia Polytechnic Institute) and Virginia Normal and Collegiate Institute (later renamed Virginia State University). In his capacities at all three institutions Vawter designed and implemented curricula that reveal his commitment to the ideals of progressive education and his larger thinking about education.

During his career, Vawter advocated that education should be a tool to improve the lives of citizens; he saw all individuals as capable of improving their lot in society. He promoted liberal and industrial education, and he believed that a proper education included training the mind, hand, and the heart. Thus, he was opposed to any form of industrial training that was separated from liberal education. While Vawter's views at times seem contradictory, his thinking was not out of line with that of progressive education as a movement. For example, when mandated to educate young girls at the Miller School, Vawter designed and implemented an effective program that gave many young women a first-class education. However, at both Virginia Polytechnic and Virginia State, he made no moves to enroll women. At that time it was not unusual for progressives to support a secondary education for women while denying them higher education.

\footnotetext{
${ }^{1}$ The Miller School of Albemarle has been called by several names in its 139-year history. As the second corporation chartered in Albemarle County, Virginia, its official name was the Miller Manual Labor School of Albemarle until the 1950s when the name was changed to the Miller School of Albemarle. Many people, however, simply refer to the institution as Miller School. Before the 1950s, many referred to the school as Miller Manual.
} 
Late nineteenth century progressive education was complex and progressive educators such as Vawter were a varied assortment. For instance, progressive educators like John Dewey and W. E. B. Du Bois believed every child should be given the opportunity to develop to their fullest potential, while progressive educators like Samuel Chapman Armstrong, J. L. M. Curry, and Robert Ogden did not espouse an egalitarian philosophy of education for all students. Regarding the purposes of education, progressive educators Du Bois and Dewey viewed education as a democratizing force in education, whereas Armstrong et al. saw education as a means of social control, particularly control of black Americans. These varied views among educational progressives reveal the conflict and complexity of progressive education itself.

In this study, I argue that Vawter was an amalgamation of the various and conflicting strands of progressive educational thought at the turn of the nineteenth and twentieth centuries. Like many progressives, Vawter advocated for the education of African Americans, thus reflecting the American traditions of egalitarianism and tolerance. On the other hand, he did not fully adhere to ideas of full equality in regards to race, religion, and gender. For instance, there is no question Vawter believed that every child had worth as long as the child was white, and he was also careful to keep Miller Manual non-denominational in regards religion. ${ }^{2}$ However, if the child was African-American, the historical record is mixed in regards Vawter's views at the three institutions where he played a major role.

\footnotetext{
${ }^{2}$ The terms industrial education and manual education can be confusing. Both terms were familiar concepts to midnineteenth century American educators, and many scholars use the terms interchangeably, however, there are important differences. Industrial education developed as a strategy to teach useful skills to the poor and other marginal classes, such as orphans, the deaf and the blind, retarded children, and Negroes. The goal was to enable these groups to grow up to be docile workers and not disaffected and dangerous. Industrial education did not have an element of social mobility. By contrast, manual labor in education developed as a way to provide healthful exercise and financial support for students of higher social strata. Andover, Amherst, Oberlin, and Wesleyan all experimented with manual labor education, which did contain an element of social mobility. Robert Engs, Educating the Disfranchised and Disinherited (Knoxville: University of Tennessee Press, 1999), 79.
} 
As was the case with both Dewey and W. E. B. Du Bois, Vawter was a progressive who believed in an education that combined the study of the classical curriculum with experiential training in the skilled crafts. Acutely aware of the need to recover from the ravages of the Civil War, Vawter believed that Virginia needed to develop educational institutions that would “...meet the growing demand for men educated in all the subjects that pertain to the physical forces and who have been trained in the applications and uses of those forces." 3 He was opposed by many critics who believed that the poor children he enrolled at Miller Manual were incapable of higher order thinking. He dealt with the same type of criticism at Virginia State where he insisted on maintaining architecture, Latin, chemistry, and other liberal subjects despite the Virginia governor's mandate that all such subjects be removed from the curriculum under the pretext that blacks were not capable of mastering such topics.

However, white racists were not his only opponents. He also faced opposition from traditional educators who believed that career paths such as engineering, agriculture, and the mechanical arts have no place in higher education. Vawter steadfastly supported the University of Virginia's Engineering Department when the dean of the University's faculty wanted to abolish the program, and he helped design the curriculum for Virginia Polytechnic Institute.

Thus, Vawter in his work throughout Virginia was a steadfast champion of education that meets the demands of industry. However, Vawter believed that the best way to educate for this demand was to create a curriculum that in addition to training in the crafts included science, history, mathematics, language, and writing. This would enable the student to understand the larger world. As the leader of a school, board rector, and noted thinker on education in the

\footnotetext{
${ }^{3}$ Charles E. Vawter, “The Promotion and Encouragement of Manufactures, the Mechanic and Useful Arts.” Speech delivered before the Virginia Mechanic's Institute, Richmond, VA, May 1889. Miller School of Albemarle archives.
} 
South, Vawter is worthy of study because in his life he dealt with the racial, pedagogical, and curricular tensions of progressive education.

\section{Why Charles Vawter?}

Adam Fairclough describes Charles Vawter in A Class of Their Own: Black Teachers in the Segregated South as a radical southern racist who was responsible for eliminating from the Virginia Normal and Collegiate Institute (VNCI) curriculum all classical studies. However, Edgar Toppin and Lucious Edwards indicate that Fairclough's research is flawed and inaccurate. Toppin and Edwards show that the remarks Fairclough ascribes to Vawter were actually stated by Governor Philip W. McKinney's State Superintendent of Public Instruction, John E. Massey and by Massey’s successor as State Superintendent, Joseph W. Southall. ${ }^{4}$

Fairclough describes Vawter as working steadfastly to limit VNCI student educational options to the same tasks that Negroes ${ }^{5}$ had performed before emancipation, whereas Toppin and Edwards write that it was Governor McKinney's aforementioned State Superintendent of Public Instruction, John E. Massey, who made the racist statements that Fairclough ascribes to Vawter. Furthermore, the changes in the VNCI curriculum, which Fairclough describes as the work of Vawter, occurred between 1890 and 1898, whereas Vawter first joined the VNCI Board of Visitors in 1902 when he was appointed rector by Governor Montague with the charge to

\footnotetext{
$4{ }^{4}$ Edgar Toppin, Loyal Sons and Daughters: Virginia State University, 1882-1992 (Norfolk: Pectoral Heritage Publishing Company, 1992), 46.

5 Americans of all ethnicities have struggled with the terms applied to Americans of African descent. Before civil rights activist Stokely Carmichael coined the phrase "black power" in an address he delivered in Mississippi in 1966, most black Americans referred to themselves as Negroes. Carmichael argued that the term Negro inferred inferiority. Among black activists, Negro soon became shorthand for a member of the establishment. Prominent black publications like Ebony switched from Negro to black at the end of the decade, and the masses soon followed. As this study is set in the last decades of the nineteenth century, and first few years of the twentieth century, the terms Negro, African-American, Afro-American, and black will all be employed. Retrieved July 20, 2017 from http://kingencyclopedia.stanford.edu/encyclopedia/encyclopedia/enc_black_power/. See also William L. Van DeBurg, New Day in Babylon: The Black Power Movement and American Culture, 1965-1975 (Chicago: The University of Chicago Press, 1992), 306.
} 
implement a curriculum of both industrial and manual education at the Petersburg school. Be that as it may, Vawter is unusual among progressive educators in that he put classical, manual, and industrial methodologies into practice. ${ }^{6}$

In making my case, I examine not only Vawter's life and thought but also his leadership at both the Miller School and throughout Virginia. At Miller Manual and Virginia Polytechnic, Vawter worked to make it possible for every student to develop higher order thinking skills, whereas at all-black Virginia State, Vawter was made Rector of the Board of Visitors after State Superintendent of Instruction Joseph W. Southall, Governor John H. Tyler, and the Virginia General Assembly had emasculated VSU to the point that it was little more than a three-year high school by eliminating the school's collegiate department. The aforementioned were convinced that higher order cognitive skills were inherently beyond the reach of the Negro student.

Vawter was named to the Board and made Rector to put into practice the program of industrial training that Southall, Tyler, and the former Superintendent of Instruction John E. Massey had mandated for VSU. We may never know if Vawter shared Southall and Tyler's views that Negroes were incapable of collegiate work, but such a contradictory notion of equality among Progressives was not unusual. Nevertheless, at VSU Vawter ignored the mandate of the Virginia government and worked steadfastly to maintain the classical curriculum for the black student body. A close examination of Vawter's work and educational ideas reveals the tenuous nature and complexity of progressive educational thought and shows how progressive educators like Vawter tried to address these contradictory ideas. In so doing, I explore Vawter's advocacy

\footnotetext{
6 "Minutes of the Board of Visitors," Virginia Normal and Collegiate Institute, Special Collections, LindsayMontague Hall, Virginia State University, 32.
} 
of manual training, his work operating a co-educational secondary boarding school, and his commitment to maintain gender segregation at the collegiate level.

Further, by placing Vawter within the progressive intellectual milieu of his day, I show how he simultaneously represented the egalitarian idealism of Progressivism that espoused equal access to education for whites and white control of the education of blacks. For example, Vawter's industrial curriculum differentiated between what was taught to white children and young adults at both the Miller Manual Labor School and Virginia Polytechnic Institute, and what was taught to young Negroes at the Virginia Normal and Collegiate Institute. In this way, Vawter was like many white progressive educators of his day - supportive of black education, but supportive of a particular type of black education.

\section{Research Questions}

This study poses the following questions:

1. What were Vawter's educational views on social class and race?

2. How did Vawter's views reflect the tensions between liberal and industrial education?

3. How did Vawter's work in building the Miller School reflect progressives' ideas about institution building and learning spaces for students?

4. How do Vawter's educational ideas reflect the tensions in progressive educational thought and the work of other progressive educators?

5. How can Vawter inform our comprehension of "progressive" educational ideas in our time?

\section{Relevant Literature}

The literature on progressive education is expansive. In this section, I will delineate the relevant historical scholarship regarding progressivism and race, liberal vs. industrial education, and the building of schools. This brief review of the secondary sources on progressive education and progressive educational thought situates this study within the literature. 
In The White Architects of Black Education, William Watkins portrays a number of white educational leaders as Social Darwinists who promoted the idea that Caucasians are inherently superior to Negroes. In particular, Watkins describes Samuel Chapman Armstrong as a patronizing paternalist who genuinely wanted to help the freedmen, but who viewed them as inherently inferior to whites. This is clearly evident in an address Armstrong delivered at a meeting of the American Missionary Society Association in Syracuse, New York in 1877 where he stated:

His worst master is still over him - his passions. This he does not realize. He does not see "the point" of life clearly; he lacks foresight, judgment, and hard sense. His main trouble is not ignorance, but deficiency of character; his grievances occupy him more than his deepest needs. There is no lack of those who have mental capacity. The question with him is not one of brains, but of right instincts, of morals and of hard work. ${ }^{7}$

Watkins describes how white architects such as Thomas Jesse Jones, Franklin Giddings, J. L. M. Curry, William Baldwin, and Robert Ogden, and northern philanthropists such as John D. Rockefeller, Andrew Carnegie, and George Foster Peabody worked in tandem with both industrialists and southern planters to achieve specific goals that increased industrial profits and maintained working-class peace in the South. Watkins writes that the common belief that the debate between Booker T. Washington and W. E. B. Du Bois determined the future of Negro education is a myth. Watkins argues persuasively that while Washington and Du Bois were important, the white architects were the real power brokers who struggled with two burning questions of the late nineteenth and early twentieth century period: "What do we do about black labor, the ex-slave, the colonial subject? How do we discipline, exploit, and civilize the Negro?"8

\footnotetext{
${ }^{7}$ William H. Watkins, The White Architects of Black Education: Ideology and Power in America, 1865-1954 (New York: Teachers College Press, 2001), 57.

${ }^{8}$ Ibid., xi.
} 
This line of thought is ascribed to Vawter by the British historian Adam Fairclough in his study, A Class of Their Own: Black Teachers in the Segregated South. Fairclough describes the role of southern black teachers from emancipation in 1865 through the era of integration a century later. Fairclough shows the successes and failures of this group of dedicated black teachers who dealt with the challenge of deducing how to help their people move ahead in a system that had been designed and implemented by white people to keep black people from advancing. One such white architect of black education described by Fairclough is Charles Vawter, whom Fairclough describes as holding extreme racist views towards Negroes and the curriculum at Virginia State University. A closer examination of the historical record shows the many errors in Fairclough's research regarding both Vawter and the operations at Virginia State.

Fairclough also describes many other prominent white educators such as the North Carolina Superintendent of Education, J. Y. Joyner, the prominent Virginia soldier, diplomat, and college professor and administrator Jabez Lamar Monroe Curry, the University of Georgia chancellor Walter B. Hill, the president of the University of North Carolina George T. Winston, and a host of other leaders who confronted black educators in an attempt to prevent the advancement of black society beyond the position of field hand and trade laborer. Fairclough is at his best in describing the work of otherwise unknown teachers who struggled to provide a quality education for their people despite the hurdles erected by the white educational leaders. These teachers had little help from the aforementioned progressive educational leaders of their day, and received little training in curriculum design, school administration, or other aspects of pedagogy. ${ }^{9}$

\footnotetext{
${ }^{9}$ Adam Fairclough, A Class of Their Own: Black Teachers in the Segregated South (Cambridge: Harvard University Press, 2007), 165-172.
} 
Interestingly, in their work, Loyal Sons and Daughters: Virginia State University, 18821992, Virginia State University Professor of History Edgar Toppin and University Archivist Lucious Edwards state that Vawter played a key role in keeping the institute in operation. They describe how Vawter ignored the mandate of the Jim Crow Era Virginia government that the collegiate program be abandoned. Furthermore, the minutes of the Virginia State University Board of Visitors of May 14, 1902 record that Vawter quietly worked to keep certain aspects of the Virginia State classical curriculum despite the mandates of both State Superintendent Massey and his successor Southall. These minutes' show that Vawter led the board to decide that although Latin had been taken out of the curriculum, those students who had begun their study of the language could continue with said study. The board and Rector Vawter also decided to establish two-year courses for the following academic disciplines: Latin, mathematics, chemistry, and architectural design. Students who completed such programs would then receive a diploma. This was diametrically opposed to the wishes of Superintendents Massey and Southall. $^{10}$

The question of what constitutes the best form of education is a theme of James D. Anderson in his work The Education of Blacks in the South, 1860-1935. Anderson reinterprets the history of black education during a critical seventy-five-year period. His thesis is that after ex-slaves attempted to create an educational system that would support and extend their emancipation, their children were pushed into a system of industrial education that presupposed black political and economic subordination. Like William Watkins, Anderson links the northern philanthropists to the accommodation of southern power interests.

10 "Minutes of the Board of Visitors", Virginia Normal and Collegiate Institute No. 1(Virginia State University), 3034. 
In his analysis of Samuel Armstrong and Booker T. Washington's Hampton-Tuskegee model of industrial education, Anderson argues that the true purpose of such schools was not to train students who could make a living as skilled craftsmen. Rather, it was to produce a stream of black teachers who would preserve the status quo: cheap black labor for southern planters, the quarantining of blacks in the south, and the maintenance of white supremacy. This was in keeping with the southern progressive belief in scientific racism - a view held by many educators, including most northern white progressives. Anderson makes this clear when he writes, "From their founding to the late 1920s, Hampton and Tuskegee were not trade schools, nor academic schools worthy of the name, but schools that attempted to train a corps of teachers with a particular social philosophy relevant to the political and economic reconstruction of the South."11

An examination of Washington's work would not be complete without a careful reading of Louis R. Harlan's study Booker T. Washington: The Wizard of Tuskegee, 1901-1915. Although Harlan's study of Washington is not a study of progressive educational thought, Harlan shows the dissatisfaction that many progressive educators held as a result of Washington's accommodations to the white segregationists. At the center of this group was W. E. B. Du Bois. Harlan relates how Du Bois was still attempting to understand Washington's contradictions in the 1950s, nearly forty years after Washington's death. There were many more Negroes, however, who viewed Washington as a savior, as someone who gave blacks hope in what was

\footnotetext{
${ }^{11}$ James D. Anderson, The Education of Blacks in the South, 1860-1935 (Chapel Hill: University of North Carolina
} Press, 1988), 75-77. 
otherwise a hopeless era. Harlan shows how Washington gave purpose and dignity to the black working-class that previously knew only toil and struggle. ${ }^{12}$

This study of the struggle to achieve black racial uplift is best told by August Meier in his classic work, Negro Thought in America: 1880-1915. Meier's central theme is the concept of double consciousness. Double consciousness describes the individual sensation of feeling as though your identity is divided into several parts, making it difficult or impossible to have one unified identity. Meier describes how Du Bois first explored this concept in his publication The Soul of Black Folks. ${ }^{13}$ He then goes on to develop how this sense of dual black identity influenced the educational philosophy that progressives such as Armstrong, Du Bois, and Washington developed and put into practice.

Before Meier, the period in African American history between the end of Reconstruction and the First World War was either avoided or ignored by historians. This time period was also the Age of Social Darwinism. The industrialization of the South occurred simultaneously with the U.S. acquisition of an empire - an empire populated by people of color. The white ruling class used Social Darwinism to justify segregation and unequal opportunity. The Jim Crow Era also pushed Negro thought away from political action towards the type of economic self-help that Booker T. Washington championed at Tuskegee and similar schools.

Washington, like Frederick Douglass before him, argued that industrial training would make Negroes so valuable and respected that citizenship rights would follow. ${ }^{14}$ This belief was challenged by Du Bois and other non-accommodationist blacks. Meier makes clear that Du Bois

\footnotetext{
${ }^{12}$ Louis R. Harlan, Booker T. Washington: The Wizard of Tuskegee, 1901-1915 (New York: Oxford University Press, 1983), 362-363.

${ }_{13}$ August Meier, Negro Thought in America, 1880-1915: Racial Ideologies in the Age of Booker T. Washington (Ann Arbor: University of Michigan Press, 1988), vii.

${ }^{14}$ Ibid., 86.
} 
objected to the fact that industrial schools were "...preparing their students in obsolete crafts, and the fact that they produced few actual artisans." ${ }^{15}$ Du Bois was voicing the same criticism that James D. Anderson states forcefully in his study.

The Washington - Du Bois rivalry is also the subject of Jacqueline M. Moore's study Booker T. Washington, W. E. B. Du Bois, and the Struggle for Racial Uplift. Moore introduces the topic of education for the masses in a succinct and clear manner. She explains that up until 1875, most Americans did not believe in universal education. Furthermore, intellectuals thought that most people were incapable of the higher order thinking incorporated in the classical curriculum.

Colleges used the trivium program, first developed during the Middle Ages, which consisted of grammar, rhetoric, and logic. This was coupled by colleges with the quadrivium of arithmetic, music, geometry, and astronomy. To take these classes it was necessary to become proficient in Greek and Latin. The difficulty of such study led many progressive educational leaders to support industrial education for the masses. This belief was adopted by men like Andrew Carnegie and John D. Rockefeller who saw a need for obedient and sober workers for the factories that developed as the industrialization of America intensified in the last decades of the nineteenth century.

Moore shows that Du Bois was not an opponent of industrial education; he simply saw that there were flaws in the Hampton-Tuskegee model. He knew the difference between a true industrial education and one that focused only on manual training. A progressive manual labor education provided skill training in new technologies, while industrial training produced a permanent working class. Such schools produced students that emerged from them with little

\footnotetext{
${ }^{15}$ Ibid., 197.
} 
chance to advance up the social ladder. ${ }^{16}$ This is a point that James D. Anderson also makes rather starkly in his study.

When one ponders Washington and his crusade to provide industrial education for young Negroes, Washington's famous rivalry with Du Bois comes to mind. Derrick Alridge analyzes the Washington - Du Bois relationship and much more in his study The Educational Thought of W. E. B. Du Bois: An Intellectual History. Alridge deconstructs the mythology behind the Washington - Du Bois rivalry and shows it to be a case of historical revisionism. Neither Du Bois nor Washington was rigid in his position. Alridge uses primary sources to make clear that both Washington and DuBois believed that children and adults should receive both classical and industrial education. As a Progressive and pragmatic educator, Du Bois was similar to Washington, Chapman, Jones, and the other luminaries of the era; however, he was distinctly different in one very important way: throughout his long career Du Bois was “... adamantly opposed to technical or practical education that was separated from liberal education."17

Du Bois was convinced that liberal arts education should be at the core of the curriculum to ensure that the recipient developed the higher order thinking skills needed to understand the rapidly changing world. Du Bois and Charles Vawter were alike is this educational belief - a belief that sets them apart from the majority of Progressives who, under the influence of the northern philanthropists, attempted to remove liberal arts from the curriculum and provide only industrial education.

\footnotetext{
${ }^{16}$ Jacqueline M. Moore, Booker T. Washington, W. E. B. Du Bois, and the Struggle for Racial Uplift (Wilmington: Scholarly Resources, 2003), 21.

${ }^{17}$ Derrick Alridge, The Educational Thought of W. E. B. Du Bois: An Intellectual History (New York: Teachers College, 2008), 65.
} 
Alridge describes how Du Bois found confirmation in support for liberal arts education when he revisited Germany in 1935 on a grant to compare German and Austrian industrial education with that practiced under the Hampton-Tuskegee blueprint. Du Bois analyzed how the Austro-German industrialists taught their employees how the industrial process worked, not just the mechanical aspects of industrial operations. For employees to comprehend this goal, they needed a background in reading, writing, history, language, and mathematics. This would enable the employee to understand the larger world of which he and his workplace were a part. This led Du Bois to state "What Germany has is not Industrial Education, but Educational Industry."18 This is identical to Vawter's belief that the classical curriculum and the workshop are symbiotic in their relationship to one another.

While Charles Vawter was working to free poor white Southerners from the prejudice of working with one's hands, Samuel Chapman Armstrong was doing similar work with poor blacks at the Hampton Institute. Today, like Vawter, Armstrong is largely a forgotten figure. There has been only one scholarly biography of Armstrong published in the last eighty years. In 1999 Robert Francis Engs published Educating the Disfranchised and the Disinherited: Samuel Chapman Armstrong and Hampton Institute, 1839-1893. Engs worked for many years as a professor of history at the University of Pennsylvania and his special interest concerned Armstrong and the Hampton Institute.

In Educating the Disfranchised and the Disinherited, Engs' descriptions of the northern philanthropists are based on most of the same sources that James D. Anderson uses in his work. However, Engs and Anderson come to very different interpretations concerning the role the philanthropists played in the crafting of the system of black education. Anderson saw a system

\footnotetext{
18 Ibid., 79.
} 
overwhelmingly designed to reduce opportunity, with foundations such as the General Education Fund working to "modernize" Southern public education on inherently unequal ground.

Engs places more emphasis on Armstrong, whom he saw as a complex individual who both catered to white racism and yet also provided opportunity to African Americans that otherwise would not have been available. Engs' Armstrong was willing to sponsor local black landowners and the black merchants in the Hampton area while simultaneously spreading an ideology of progressive industrial education that fit neatly with segregation and disfranchisement. Nevertheless, one should be skeptical of Engs' account of Armstrong's work because a number of other sources contradict much of what he describes.

The most enduring work on progressive educational thought is Merle Curti's The Social Ideas of American Educators. This study will examine and expand upon Merle Curti's belief that "... an increasing number of [late nineteenth century] educators advocated manual training and industrial education as the best specific means of counteracting radicalism on the part of the working masses."19 These educators were concerned that the ideas of Marx and other socialists would infiltrate the trade union movement and bring about the dreaded proletarian revolution. These progressives, however, were also faced with other problems.

The migration of a large percentage of the population from the countryside to cities had transformed Americans into a largely urban people. This migration was coupled with the enormous numbers of immigrants who were drawn to work available in the factories and shops of America's cities. How these new urban arrivals were to be trained and how their children were to be educated were questions that concerned progressive educators. The changing status

\footnotetext{
${ }^{19}$ Merle Curti, The Social Ideas of American Educators (Totowa, New Jersey: Littlefield, Adams \& Co., 1935), 221.
} 
of women, the emancipation of the slave, and the decreasing social mobility complicated matters as well. The end result was a great struggle over what should be taught, how it should be taught, and to whom it should be taught.

\section{Liberal vs. Industrial Education}

Perhaps the best-known study on Progressive Education is Lawrence Cremin's The Transformation of the School: Progressivism in American Education 1876-1957. In his study Cremin argues that progressive educational ideas developed out of the American reform and humanitarianism movements that emerged as a response to the excesses of the Industrial Revolution and the subsequent Gilded Age. Cremin analyzes how Horrace Mann's belief that everyone should be educated gave birth to the progressive educational idea that schools can be used to improve the lives of individuals from all elements of society.

But in order to accomplish such a goal, the concept of education would have to change in a number of different ways. The curriculum and function of school would have to adjust to meet the needs of the new and different kinds and classes of students that were enrolled. Secondly, it meant applying in the classroom the principles derived from the new research in the social sciences. Finally, the school's program would have to be expanded to include concerns about the students' values, their future vocations, family life, and health.

These progressive beliefs can be seen in the work of Vawter, Armstrong, Washington and many other late nineteenth century educators. These men were also influenced by the progressives' belief in pragmatism. Pragmatism emphasized practical over abstract knowledge. Cremin is a rich source of information about the rise and fall of manual training education in the 
United States during the era of Vawter's work, covering the last two decades of the nineteenth century and the early years of the twentieth century. ${ }^{20}$

It is interesting to note that at the same time that educational experts -- progressives like John Dewey and Vawter -- were proposing that craft skills be taught as an essential part of the school curriculum; a second pernicious development was beginning to worm its way into the field of education. This was the gradual but steady intrusion into school organization and curriculum development by the business community. This development began in the last years of the nineteenth century with the involvement of men like Rockefeller and Carnegie, and this continues up to the present.

Raymond E. Callahan, in Education and the Cult of Efficiency, published in 1961, describes this process. Callahan was the first to challenge Ellwood Cubberly's triumphant public-school thesis that the democratic United States was exceptional. ${ }^{21}$ Beginning in about 1900, educational administration began to adopt business values and practices. This was in keeping with the progressive belief that organizations should be pragmatic. Pragmatism emphasized practical over abstract knowledge. School administrators started to refer to themselves as "school executives" rather than as scholars and educational philosophers. ${ }^{22}$ Callahan bemoans this occurrence and asks why this was so. Schools are not factories, they are not a business. ${ }^{23}$ Callahan believes that this intrusion was a result of the Gilded Age. This was the era of the larger than life businessman. It was the age of Rockefeller, Morgan,

\footnotetext{
${ }^{20}$ Cremin describes the influence that the 1876 Philadelphia Centennial's Russian Exhibit had on President John D. Runkle of the Massachusetts Institute of Technology and his implementation of manual training education. In turn, the work of Runkle was a significant influence on the curriculum and educational methodologies that Vawter designed and implemented at the Miller Manual School. See Lawrence A. Cremin, The Transformation of the School: Progressivism in American Education, 1876-1957(New York: Alfred A. Knopf, 1961), 25.

${ }^{21}$ Ellwood Cubberley, Public School Administration: A Statement of the Fundamental Principles Underlying the Organization and Administration of Public School (Boston: Houghton Mifflin, 1916).

${ }^{22}$ Raymond E. Callahan, Education and the Cult of Efficiency (Chicago: University of Chicago, 1962), 11.

${ }^{23}$ Ibid, vii.
} 
Carnegie, Vanderbilt, and other titans of industry. These men were, generally, anti-intellectual and viewed scholars as impractical dreamers. This was the time when terms such as "ivory tower" and "highbrow" were coined. These are pejorative expressions which castigate intellectuals as out-of-touch with ordinary people and too lacking in realism, common sense, and virility because of their intellectual interests. Nevertheless, whether warranted or not, the American public held these industrial moguls in high esteem. ${ }^{24}$

This adherence to pragmatic thinking led to the redesign of American primary and secondary education. David B. Tyack defines this transition in his work The One Best System: A History of American Urban Education. In the post-Civil War Era, American educators were moving rapidly away from the one-room, rural schoolhouse system to the large egg-crate schools. These new schools had separate classrooms for every teacher, uniform courses of study, and graded classrooms, i.e. third grade, second grade, etc. C. William Brubaker describes the evolution of architectural school design in his work Planning and Designing Schools. Between 1850 and 1920, the one-room wooden school in which all ages of school children were educated was replaced by buildings of two to four stories with brick walls, axial plans, pitched roofs, built primarily in historical styles such as Victorian or Classical. Vawter oversaw at Miller Manual the construction of four story buildings in the Victorian style with exuberant details that harked back to earlier cultures. ${ }^{25}$

These uniform courses of study and inflexible delivery methods soon led to dissatisfaction among progressive educators who began to attack the "old one best system" for its undifferentiated structure and regurgitation of methods. Vawter was one of those change agents who designed and implemented a curriculum suited to both the new industrial period and the

\footnotetext{
${ }^{24}$ Ibid, 2.

${ }^{25}$ C. William Brubaker, Planning and Designing Schools (New York: McGraw-Hill, 1998), 1-4.
} 
poor children who had been excluded from education in previous eras. Vawter, however, was also an educator who differentiated instruction on the basis of ability. Booker T. Washington was another of those change agents.

It is also instructive to understand the role that religion played in the childhood of progressive educators. Charles Vawter is emblematic of progressive educators in that he came of age during the Third Great Awakening, and this experience shaped his later career as an educator. Jared R. Stallones analyzes the influence of such a background on progressive educators in his study Conflict and Resolution: Progressive Educators and the question of Religion. Stallones shows how the number of Americans that he identifies as "religious adherents" increased dramatically between 1776 and 1896.

The result was a significant number of educational professionals who were brought up in religious environments but upon reaching adulthood were unable to adhere to the religious tenets of their youth. Stallones argues that they instead devoted themselves to social and political reform. Vawter was just such a man. Stallones shows that he was what is known as a Reinterpreter, an educator who adopted a modernistic worldview and transformed his religious zeal into educational pursuits. Vawter believed in the inherent goodness of mankind and devoted himself to rescuing hundreds of needy children. His deep social conscience was an outgrowth of the religiosity of his youth. ${ }^{26}$ In addition to the works mentioned in this relevant historiography, numerous other studies of Progressive Education will be employed in my research and analysis.

\footnotetext{
${ }^{26}$ Jared R. Stallones, Conflict and Resolution: Progressive Educators and the question of Religion (Charlotte: Information Age Publishing, 2010), xiv-xv, 2, \& 20.
} 


\section{Methodology}

This project is a historical study. As a result, it draws primarily on archival sources and primary materials. A voluminous trove of documents on or related to Vawter exists across the State of Virginia. The Special Collections of the University of Virginia's Alderman Library hold a number of important documents. In particular, Clara H. Robertson's Keys to the History of Miller School of Albemarle Virginia contain numerous letters written by Charles Vawter to members of the school community. Some are directions to teachers that shed light on Vawter's management style and educational philosophy. Others show how he interacted with patrons and elected officials. Furthermore, the Alderman Special Collections houses various copies of Miller School publications, such as The Blue Ridge Blast, published in 1905, and the 1927 publication Miller Memories, as well as numerous annual Miller School Catalogues that show when the school was officially chartered by the State Corporation Commission as the Miller School of Albemarle doing business as the Miller Manual Labor School of Albemarle. The Blue Ridge Blast and Miller Memories also contain many remembrances by early students and faculty who were part of the school community during the Vawter years.

The Albemarle County Historical Society is another rich depository. Various editions of their publication, Magazine of Albemarle County History, include many articles pertaining to the establishment and early years of the Miller School. Additionally, the Historical Society collections include a number of books about the Charlottesville area that contain articles about the Miller School. An example of such is Mary Rawlins' work The Albemarle of Other Days. The Jones Memorial Library in Lynchburg houses a number of documents about Samuel Miller's establishment of both the Lynchburg Female Orphan Asylum and Miller's intentions for the Miller School of Albemarle. The Campbell County Court House also holds important 
documents concerning the life of Samuel Miller. The documents found in the Alderman Library's Special Collections show numerous links to documents that are found in the Virginia Department of Historic Resources in Richmond. Vawter's associations with both Virginia Tech and Virginia State University also need to be included.

At Virginia State, their Special Collection Archives houses the minutes of the Board of Visitors during the years that Vawter was the board chair. These minutes were especially helpful in ascertaining the errors contained in Adam Fairclough's study. At Virginia Tech, the Virginia Tech Magazine as well as the Newman Special Collections Library and archives contains the Vawter Family File as well as several books on the history of Virginia Polytechnic Institute. In particular, Duncan Lyle Kinnear's The First 100 Years: A History of Virginia Polytechnic Institute and State University is a rich source of information regarding Vawter's role in Blacksburg. The Alderman Library's Special Collections at the University of Virginia also contains a number of rare histories of the Blacksburg school.

The Miller School of Albemarle possesses the richest source of material on Vawter and the Miller School. Although voluminous, these materials have never been systematically organized and centralized. An industrious and loyal alumnus of the Miller School of Albemarle Class of 1961, Bobby Shaw, works tirelessly to rectify this confusion. He has been an asset in my research. Bobby Shaw is not the only alum to be a valuable resource; so too are many of the other older members of the Alumni community. I interviewed an aging alumnus who worked in the Edison power house during his student years. Although Charles Vawter was long in his grave during this student's time at Miller, the school was still largely run as Vawter had directed. The daily schedule, the curriculum, the emphasis on "mind, hands, and heart" education, and the flipped classroom style of instruction were still all in practice during this alum's years at Miller. 
One can see that the topic of Charles Vawter and his contribution to the field of education is not limited by access to resources. This researcher should be able to ascertain not only how Vawter borrowed from Pestalozzi and others, but also what it was that he developed which was new to the field of education. The study will also examine Vawter's contradictory influence at Virginia's colleges and universities, as well as the problems he shared in common with Armstrong, Washington and other progressives.

\section{Assumptions}

The following assumptions apply to this study:

1. Charles Vawter's recorded thoughts about education were so broad and detailed that a researcher should be able to interpret these thoughts and construct a philosophy of education.

2. The primary source documents are authentic, accurate reflections of the ideas and thoughts of Charles Vawter.

3. Historical research is capable of helping analysts make connections between events and ideas.

4. This study will make a significant contribution to the scholarly dialogue surrounding Vawter's life and work.

\section{Scope of Study}

This study will consist of:

1. Review of the secondary literature about Charles Vawter, the Miller School of Albemarle, and Albemarle County, Virginia during the last quarter of the nineteenth century and the early years of the twentieth century.

2. Collection and review of the significant primary sources related to Charles Vawter, the Miller School of Albemarle, Virginia Polytechnic Institute, and Virginia State University.

3. A discussion of Vawter within the social and political context of his time, comparing his views with those of his contemporaries.

4. Analysis of the development of Vawter's ideas on education. 


\section{Limitations of the Study}

This study is not intended to provide a comprehensive account of Vawter's life, rather the primary focus of the study will be on the educational ideas he espoused during his professional career.

\section{Organization of the Study}

Chapter I provides an overview of the study, including introduction, background of the problem, significance of the study, statement of purpose, scope of the study, research questions, methodology, assumptions, limitations, and organization of the report.

Chapter II provides an analysis of the purpose of progressive education and compares and contrasts that analysis with Charles Vawter's educational philosophy.

Chapter III explores Vawter's work and educational thought regarding race and education in Virginia in general and Virginia's state colleges in particular.

Chapter IV examines Vawter's work and educational thought regarding industrial education and classical or liberal education.

Chapter V describes Vawter's work and progressive educational ideas in the building of the Miller School and his work at Virginia Tech.

Chapter VI concludes the study with a reconsideration of Progressive Education and analyzes the connotations of Vawter's work in contemporary education. 


\section{Chapter Two}

\section{The Purposes of Progressive Education}

"Progressivism" was a many sided reform drive that emerged as a national movement in the last two decades of the nineteenth century, flourished in the early years of the twentieth century, and then faded away as a force by the 1920s. ${ }^{27}$ Progressives did a lot of beneficial reform work; they regulated big business and railroads, broke up the Standard Oil Company and other monopolies, Created the Federal Reserve banking system, proposed and ratified four amendments to the United States Constitution, enacted The Pure Food and Drug Act, and worked to end vice and corruption. Nevertheless, progressives ignored the issue of race and many held different views about the abilities of poor whites. ${ }^{28}$

In this chapter, I identify and describe the purposes and unifying beliefs of Progressive Education. In so doing, I explain how Progressive Education influenced schools and education throughout the United States. However, I also recount that not all progressives agreed about how these beliefs were to be implemented, particularly since positions on race, gender, and social class sometimes led to contradictory practices. Charles Vawter was a progressive who said very little publicly or in his writings about race or gender, but in his work, he supported both blacks and women in obtaining a classical education and the benefits such an education provided. Finally, Vawter was outspoken in his belief that poor whites should be provided with all of the components of Progressive Education.

Historians mark the beginning of the Progressive Era around the date of 1880. However, it is rather simplistic to state that the Progressive Era only began at that date since the cultural

\footnotetext{
${ }^{27}$ Walter Nugent, Progressivism: A Very Short Introduction (New York: Oxford University Press, 2010), 1.

${ }^{28}$ David W. Southern, The Progressive Era and Race: Reaction and Reform, 1900-1917 (Wheeling, Illinois: Harlan Davidson, Inc., 2005), 1.
} 
factors that evolved into the Progressive Era actually developed years earlier and lie in the idealism that had marked the American Experiment since the Revolutionary Era. Founding Father Thomas Jefferson was a supporter of free public education because he believed that it was necessary to have an informed populace capable of making intelligent decisions.

Similarly, great pre-Civil War proponents of public schooling such as Horace Mann, Henry Barnard, and John Pierce, like Jefferson, believed that freedom is dependent on a welleducated populace, and that such a populace could only be achieved if there were public schools. ${ }^{29}$ However, not all proponents of educational reform were in favor of public schooling. For example, the English philosopher Herbert Spencer was a lifelong proponent of private schooling and viewed public school as a poisonous version of welfare. Although English, Spencer had a profound influence on numerous nineteenth century American educators such as Harvard president Charles Eliot. Not impressed with traditional educational methodology, Spencer in his 1860 book Education: Intellectual, Moral, and Physical spelled out the categories that education should serve in preparing a student for what Spencer called "complete living." In particular, Spencer's promotion of science had a profound influence on American schoolmen and their attempts to redesign the curriculum. ${ }^{30}$

Additionally, religion played a role in bringing about the Progressive Era. The growing religiosity of the American public increased dramatically during the first half of the nineteenth century as a result of the Second and Third Great Awakenings. A developing movement in many Protestant churches was the "Social Gospel." This was the idea that unregulated capitalism was socially harmful, unjust, and anti-Christian. This idea gained strength as the

\footnotetext{
${ }^{29}$ Cremin, 8-9.

${ }^{30} \mathrm{Ibid}, 92-94$. Spencer determined that these activities are “... (1) those ministering directly to self-preservation, (2) those that secure the necessities of life, (3) those concerned with the rearing and disciplining of offspring, (4) those that maintain proper social and political relations, and (5) those devoted to the gratification of tastes and feelings."
} 
excesses of the Industrial Revolution became obvious. ${ }^{31}$ John Dewey in particular was concerned about this development as he viewed the Industrial Revolution negatively. He believed it had created "disharmonious communities." 32

Before the Gilded Era there were few stark economic differences, but with the development of large corporations run by men like Carnegie, Rockefeller, Morgan, and many others, huge inequalities in income and social standing became pronounced. By 1918 John D. Rockefeller owned 1.6 percent of the entire national wealth; his wealth in the currency of 2010 amounted to more than 192 billion dollars, which would be more than twice the value of Bill Gates and Warren Buffet's 2010 holdings if they were combined. ${ }^{33}$

Furthermore, the industries these titans developed needed increasing supplies of cheap labor. This led to the boom in immigration that occurred in the last decades of the nineteenth century. Millions of "New Immigrants" arrived from primarily southern and eastern Europe as well as from China and other parts of southeast Asia. ${ }^{34}$ This led to shortages in housing, food supply, medical care, and educational opportunity. Slums quickly developed into which these New Immigrants and their children sought shelter. Whereas the Old Immigrants, who arrived prior to 1880 , tended to move inland and settle as farmers, the New Immigrants stayed in cities and lived in ghettos where they retained their language and culture.

Their failure to quickly adapt to American cultural norms was one factor that led to the development of prejudice towards the New Immigrants. For example, a member of the

\footnotetext{
${ }^{31}$ Nugent, 59

32 John Howlett, Progressive Education: A Critical Introduction (New York: Bloomsbury Publishing, 2013 ), 186.

33 Ibid, 86.

34 The term "New Immigrants" refers to the wave of immigrants who arrived in the United States during the last decades of the nineteenth century. Most of these immigrants were from southern and eastern Europe and China. Unlike the "Old Immigrants", who left Northwest Europe, the "New Immigrants" were darker in skin color, were not Protestant Christians, and favored dress and diet that was very different from the practices of Northwest Europe.
} 
Daughters of the American Revolution asked: "What sort of American consciousness can grow in an atmosphere of sauerkraut and Limburger cheese .... Or what can you expect of the Americanism of a man whose breath always reeks of garlic?"35 Many of these Anglophiles believed that the solution was to "Americanize" these immigrants and the best way to do that was through education. They needed to be Anglicized and learn the “... Anglo-Teutonic conceptions of law, order, and government...."36 Thus one of the motivations for what became known as Progressive Education was the desire to use education and the school as a means of both "Americanizing" these immigrants and realizing the promise of American life for all citizens.

To realize the "promise of American life" Progressive Educators held many beliefs. However, the noted scholar of Progressive Education, Lawrence Cremin, writes that there is no standard definition of Progressive Education because different educational practitioners had starkly different ideas about what Progressive Education involved. Furthermore, Cremin makes the case that Progressive Educators were frequently self-contradictory. For example, many progressives believed in democratic values and merit based advancement while they simultaneously held racial and gender prejudices. ${ }^{37}$

\section{The Unifying Beliefs of Progressive Education}

Nevertheless, there are some unifying beliefs. Progressive Educators believed that schools could be used to improve people's lives. They believed that this could be accomplished in several ways. First, the school's program needed to be expanded to include concern for the student's health, career choices, and family life. Secondly, teachers needed to use in their

\footnotetext{
${ }^{35}$ Cremin, 68.

${ }^{36}$ Elwood P. Cubberley, Changing Conceptions of Education (Boston: Houghton Mifflin, 1909), 15-16.

37 This is a topic that will be explored in chapter three of this study.
} 
classrooms the new pedagogical principles that psychology and the other social science fields had recently discovered. Additionally, teachers needed to tailor their instruction to the new and diverse student body which had developed as a result of the wave of "New Immigrants." Finally, Progressive Educators believed that schools could help democratize society without making the culture of the United States banal in character. ${ }^{38}$

These educators held that the traditional school curriculum did not meet the needs of the new industrial society. Rather, the classical curriculum was prejudicially favorable to the upper social class whose children were preparing for collegiate study. Progressive Education was a protest against this traditional schooling with its rigid social barriers. At its core, Progressive Education was an attempt to realize the ideal that all men are created equal and that one's status should depend on merit. ${ }^{39}$

Progressives believed that all members of society can and should be able to share in the benefits produced by the scientific advances of the nineteenth century. ${ }^{40}$ The famous director of Chicago's Hull House, Jane Adams, famously remarked, "We have learned to say that the good must be extended to all of society before it can be held secure by any one person or class; but we have not yet learned to add to that statement, that unless all men and all classes contribute to a good, we cannot even be sure that it is worth having." It was this idealism that motivated and empowered the Progressive Movement and led to so many social and political achievements. ${ }^{41}$

\footnotetext{
${ }^{38}$ Cremin, viii-x.

${ }^{39}$ Ibid, 88.

${ }^{40}$ As noted elsewhere in this study, many progressives held contradictory opinions in regards race, gender, and social class.

${ }^{41}$ Ibid, ix.
} 


\section{The Practice of Experiential Education}

To achieve this ideal, most Progressive Educators held several pedagogical beliefs in common. Most importantly, they believed in learning by doing, or what today is known as experiential education. This method utilizes a curriculum where students first acquired knowledge through study, which was then followed by the action of doing what had been studied. ${ }^{42}$ This methodology has ancient roots. Aristotle stated that we learn by doing, and the eighteenth century Swiss educator Johann Pestalozzi believed that students learn best through active inquiry rather than rote memorization. Students should be able to relate their studies to their everyday lives rather than to abstract concepts. ${ }^{43}$

Thus, it is not surprising that progressives like Booker T. Washington, Samuel Armstrong, and Charles Vawter all believed in an integration of classroom instruction with the actual building of items in the workshop. At Washington's Tuskegee Institute, the classroom and the workshop were often next to one another. A visitor might pass through the carpentry shop and witness a group of students making interior finishings, such as moldings and door jambs, while in an adjoining room a group of students would be working with an instructor on learning how to draw-up and execute construction contracts for erecting buildings. ${ }^{44}$ Similarly, Armstrong was intent in his belief that industrial labor training was a powerful part of the school curriculum. At Armstrong's Hampton Institute, students performed physical tasks in the morning and then received classroom instruction in the afternoon. ${ }^{45}$ The boys' manual work was

\footnotetext{
42 Stallones, 52.

${ }^{43}$ Henry Holman, Pestalozzi: An Account of His Life and Work (London: Longman Green \& Co., 1908$), 34$.

${ }^{44}$ Booker T. Washington, Working With the Hands: Being a Sequel to "Up From Slavery" Covering the Author's Experiences in Industrial Education at Tuskegee (New York: Doubleday, 1904), 69-70.

${ }^{45}$ Robert Francis Engs, Educating the Disfranchised and Disinherited: Samuel Chapman Armstrong and Hampton Institute, 1839-1893 (Knoxville: University of Tennessee Press, 1999), 20.
} 
farming crops which the school sold on the northern market. The girls did housework as their morning labor.

John Dewey was another progressive who believed in the value of experiential education. At his Laboratory School in Chicago, Dewey designed a program where the students would not be confined to passive activities such as listening and reading - activities where their minds would be dependent on the mind of the teacher or the author. He wanted his students to actively inquire and to discover on their own the lessons of his curriculum. ${ }^{46}$ Dewey also held that exercise is very important to a child's growth. He believed that the idea of bodily activity hindering the working of the mind was an absurd idea. ${ }^{47}$ At his Laboratory School, students learned arithmetic by cooking, where they learned to follow recipes, and by building furniture and constructing buildings, which taught them the value of precise measurements. ${ }^{48}$

\section{The Development of an Integrated Curriculum}

Progressive educators also believed in an integrated curriculum focused on thematic units. An integrated curriculum was about making connections across curriculum subjects to real life topics that could be as diverse as cooking, sewing, gardening, and a host of other activities. John Dewey was a key practitioner of this approach. He planned carefully designed activities in cooking, weaving, and the manual arts because he found that these activities led the students to gain important information germane to chemistry, physics, zoology, and other scientific fields. Dewey was very careful in selecting and planning his activities. He believed that there were three criteria that should be used in implementing activities: they should be in harmony with the children's stage of development, they should be aligned with helping each child prepare for the

\footnotetext{
${ }^{46}$ John Dewey, The School and Society: Three Lectures (New York: McClure, Phillips \& Co., 1900), 48.

${ }^{47}$ John and Evelyn Dewey, Schools of Tomorrow (New York: Knickerbocker Press, 1915$), 9$.

${ }^{48}$ Laurel N. Tanner, Dewey's Laboratory School: Lessons for Today (New York: Teachers College Press, 1997), 4748.
} 
"social responsibilities of adult life," and they should develop in the children habits of acute observation. ${ }^{49}$

Charles Vawter designed and put into practice this type of integrated curriculum at the Miller School. This can be seen in the Miller School's teaching of what was then known as electrical engineering. The course in electricity occurred in the school's Laboratory Building and consisted of lectures on single-pole and multiple-pole dynamos, electrical designs, and the practical wiring of motors and incandescent lamps from continuous current dynamos. The student was judged competent in electrical engineering when he could design a continuous current circuit, powered by a two-pole dynamo, and make diagrams showing the connections of various motors in the boiler room to the dynamo in the school's Power House. ${ }^{50}$ To successfully implement this type of integrated curriculum required superior teachers. Vawter, like other progressives, viewed the demands on a teacher as twofold: the teacher must not only be a master of his subject, but he must also possess an awareness of the common experiences of childhood that can be used to lead children toward an understanding of the teacher's academic discipline. ${ }^{51}$

Like Dewey, Vawter believed that children should prepare for the responsibilities of the adult world by experiencing a broad range of activities. In a speech, he delivered to the Virginia Mechanic's Institute in 1889 , he stated that "It is not desirable for a boy too early to learn a trade. Learning a trade circumscribes, confines, dwarfs."52 Vawter believed that learning should begin at what he called the "bottom" - in the elementary classes. Instead of beginning in the machine shops, the curriculum began in the elementary classrooms of the Miller Manual School. ${ }^{53}$

\footnotetext{
${ }^{49}$ Ibid, 83-85.

${ }^{50}$ Miller School Catalogue (Miller School, 1902-03), 65.

${ }^{51}$ Cremin, 138.

${ }^{52}$ Charles E. Vawter, "The Promotion and Encouragement of Manufactures, the Mechanic and Useful Arts," Speech delivered before the Virginia Mechanic's Institute, Richmond, VA, May 1889. Miller School of Albemarle Archives, 13.

${ }^{53}$ Miller Memories (Miller School, 1927), 21.
} 
Like Horace Mann and John Dewey, Vawter viewed the interests of the school as the same as the greater interests of the larger society. The aim of education was to fit children not only for society but also to enable them to have a rich personal life ${ }^{54}$ Towards this end, Vawter aimed to create a school that would combine classical and manual training in the primary, intermediate, and the secondary levels.

\section{The School as a Welcoming Place}

Dewey and many other Progressives believed that the school should be a very welcoming place. In Dewey's Lab School and Parker's schools in both Quincy and Cook County, school was organized as "a model home, a complete community, and an embryonic democracy." The emphasis was on sharing, self-expression, and self-discovery. Parker, following the methods of Pestalozzi, Froebel, and Herbart, made the study of art the center piece of the curriculum because he viewed painting, drawing, and modeling as essential components of expression. Science was introduced as a form of nature study. The students used neighboring fields and lakes as sites for observation. They made drawings and wrote descriptions which correlated to their work in language and art. This then led naturally to the introduction of laboratory work in the classroom. Mathematics was frequently introduced through both their laboratory work and manual training. The students would build their own equipment which, like Dewey's methodology at Chicago, taught them the importance of measuring, cutting, fitting and securing. ${ }^{55}$

Many other Progressives believed in teaching mathematics in the same style as Dewey. In particular, practitioners of manual training such as Vawter and Calvin Woodward at the St.

\footnotetext{
${ }^{54}$ Curti, 132.
}

${ }^{55}$ Cremin, 132. 
Louis Manual Training School emphasized "learning by doing." 56 For boys, this was an opportunity to learn carpentry, foundry skills, and electrical work. They made items appropriate for each season - skis and sleds in the winter and kites in the spring. Girls also learned also by doing -- they cooked, sewed, embroidered, and practiced a number of other crafts associated with the home. ${ }^{57}$

\section{Pragmatism as a Controlling Principle}

This form of instruction also spoke to another hallmark of Progressive education, the belief in pragmatism. Pragmatism was not a set of doctrines but a way of approaching life's challenges. Merriam-Webster defines pragmatism as a reasonable and logical way of doing things or thinking about problems that entails dealing with specific situations instead of ideas and theories. ${ }^{58}$ Charles Pierce introduced this concept in a paper he wrote in 1878 , and the noted psychologist and philosopher William James popularized the idea in educational circles. In his book Pragmatism and The Meaning of Truth, James argues that Socrates, Aristotle, Locke, and others practiced pragmatism without using the term. ${ }^{59}$

Simultaneously with these developments, John Dewey was troubled by how education was delivered to children. Students sat passively in rows of desks and listened to teacher lectures. They were then expected to recall on graded assignments the facts contained in these lectures. The results often left the student incapable of connecting these facts to real life situations. The goal in pragmatic educational pedagogy is connecting knowledge and

\footnotetext{
${ }^{56}$ As stated in chapter One of this study, the terms industrial education and manual education can be confusing. Both terms were familiar concepts to mid-nineteenth century American educators, and many scholars use the terms interchangeably, however, there are important differences.

${ }^{57}$ Cremin, 143-144.

${ }^{58}$ Retrieved July 26, 2016 from http://www.merriam-webster.com/dictionary/pragmatism

${ }^{59}$ William James, Pragmatism and the Meaning of Truth (Cambridge, MA: Harvard University Press, 2000 ), 30.
} 
experience. Pragmatism is less concerned with the logical order of subjects or lessons than with students' psychological needs. ${ }^{60}$

Dewey speculated that children's own individual interests and instincts should drive the learning process. Dewey then founded his famous Laboratory School at the University of Chicago in 1896. The Lab School's curriculum was rooted in European ideas about education and included emphasis on math and language concepts to be learned as children moved about the classroom freely and explored their own interests. The results of his experiments in Chicago were so positive that Dewey became an advocate for pragmatic methods of learning. Dewey believed that children must be interested in a topic for meaningful connections to be made and only then would real learning occur. Students would then feel a sense of accomplishment which would develop a love for learning. The success of his experiments convinced Dewey that thinking and acting are part of a single process. ${ }^{61}$

Pragmatism appealed to Progressive Educators' sense of democracy. They viewed the traditional form of education as inherently biased towards the upper social classes who could afford to have their children tutored in the trivium and quadrivium. ${ }^{62}$ Charles Vawter, like Dewey, believed that all children can learn and that interest in learning is linked to the study of topics that interest the child. Vawter's background helped to inculcate these progressive beliefs. Monroe County Virginia, where Charles Vawter was born in June of 1841, was a land of hardscrabble farms where life was frontier-like and the inhabitants took pride in hard work and a selfsufficient, pragmatic lifestyle. It was an environment that valued accomplishment over

\footnotetext{
${ }^{60}$ Louis Menand, The Metaphysical Club (New York: Farrar, Straus, and Giroux, 2001), 360.

${ }^{61}$ Ibid, 360.

${ }^{62}$ The Trivium was the lower division of the seven liberal arts and consisted of grammar, logic, and rhetoric. The quadrivium are the four subjects taught after teaching the trivium; these subjects are arithmetic, geometry, music, and astronomy. See C. T. Onions, ed., The Oxford Dictionary of English Etymology (Oxford, England: Oxford Press, 1991), p. 944.
} 
genealogy. Vawter grew up in a home that valued not only education but also the handcrafts. It was a home conducive to rearing practical children, a place where the established norms of eastern Virginia were not held in high esteem. In Monroe County, it was a sign of success to know how to farm, hunt, slaughter, cure meats, and to perform carpentry, masonry, and a host of other forms of skilled labor. ${ }^{63}$

These democratic, pragmatic beliefs were central to Vawter's educational philosophy. This is evident in an 1889 speech he delivered to the Virginia Mechanic's Institute where Vawter stated that the goal of a Miller education was "to train a child how to be mentally active, socially useful, and morally good."64 In a 1902 interview with Leslie's Weekly reporter Helen Gray, Vawter stated how deeply he believed that with proper training in the right environment every child can be successful. He told Gray, "It must be remembered that none of these boys would have had any opportunity of becoming anything higher than an uneducated workman .... I can conceive of no better way of doing good than in the way of the Miller Manual School. It works on the most hopeful material that the country has, the healthful children of the poor."

Vawter then went on to describe to Gray that traditional schools made no provision for children that they deemed to be dull. Such schools labeled the student as a fool and sent the child out in the world with no talents beyond that of unskilled laborer. Vawter stated that in the course of training at Miller Manual, “...if he [the dull boy] cannot get through arithmetic, he can get through something in our industrial course, and some of the very best results of this school's training have been on the dull boy." This was how Vawter achieved his goal of teaching all

\footnotetext{
${ }^{63}$ Oren F. Morton, A History of Monroe County West Virginia (Dayton, Virginia: Ruebush-Elkins Co., 1916), 137.

${ }^{64}$ Charles E. Vawter, "The Promotion and Encouragement of Manufactures, the Mechanic and Useful Arts," Speech delivered before the Virginia Mechanic's Institute, Richmond, VA, May 1889. Miller School of Albemarle Archives, 13.
} 
students to be mentally active, socially useful, and morally good. ${ }^{65}$ We can also see Vawter practicing a type of pedagogy similar to what is today known as differentiated instruction.

\section{The Teaching of Morality}

Certainly, the teaching of morality is another hallmark of Progressive Education. In fact, progressivism has been described as a “... secularized version of fundamentally religious impulses." Jared Stallones posits that the Second and Third Great Awakenings created an overtly religious atmosphere in the United States. Between 1776 and 1916 the number of Americans who identified as "religious adherents" increased from seventeen percent to fiftythree percent. This transformation had a deep influence on the educators who came of age during this period. Vawter was a product of this era; many progressive educators were brought up in religious environments but as adults were not able to adhere to the religious tenets of their youth. Instead, they devoted themselves to social and political reform. ${ }^{66}$

Stallones identifies three types of progressive educators who were influenced by the religiosity of their youth. The first type is the Integrator. They carry the religion of their youth into their adult work, are overtly religious, and exhibit a missionary zeal to their work. Samuel Armstrong is a good example of this type. The second type is the Reinterpreter. They adopt a modernistic worldview and transform their religious zeal into educational pursuits. Charles Vawter and John Dewey are prime examples of this type. The third type is the Denier. They reject the religiosity of their youth and fail to include religious traits in their educational work. ${ }^{67}$

As a Reinterpreter, Vawter believed in the inherent goodness of mankind and devoted himself to rescuing hundreds of needy children. ${ }^{68}$ Perhaps Vawter like John Dewey lacked a

\footnotetext{
${ }^{65}$ Helen Gray, "Educating Poor White Children: The Story of a Southern Industrial School," Leslie's Weekly, 394.

${ }^{66}$ Stallones, xii-xv.

${ }^{67}$ Ibid., 2.

${ }^{68}$ Ibid., 12.
} 
sense of personal peace and a conviction that he was in good standing with God. It is likely that Vawter was influenced by the late nineteenth century belief that religious faith helps develop a healthy self-image, thus he incorporated religious activities into the Miller program. ${ }^{69}$ The entire school attended morning and evening worship in the chapel on weekdays, and on Sunday there was Sunday school, a service, and a sermon. ${ }^{70}$

\section{The Teaching of Social Responsibility}

Inculcating students with a strong set of moral beliefs is related to another core purpose of Progressive Education - the teaching of social responsibility. Social responsibility is an ethical framework that posits the idea that we are all obligated to act for the benefit of society at large. This responsibility can be either active or passive. Citizens can actively engage in activities that advance social goals, or they can avoid engaging in activities that are socially harmful. In his Chicago school, Dewey intended that the spirit of community service be a treasured part of the school's culture. Working on cooperative learning projects meant that each child's contributions added to a common purpose. It was Dewey's intent and hope that such projects would build lifelong habits. Dewey believed community service should happen after students have reflected on social problems and then developed goals. ${ }^{71}$

Vawter accomplished the task of teaching social responsibility at Miller Manual by implementing a number of practices in the daily schedule of the school. For example, although most Miller students came from the lower social classes, there were a number of students who came from privileged homes, such as the sons of professors at the University of Virginia. In the school's dining hall, rather than having servants wait on the tables, all Miller students took turns

\footnotetext{
${ }^{69}$ Ibid., 63.

${ }^{70}$ Miller School Catalogue (Miller School, 1901), 87.

${ }^{71}$ Tanner, 3-5.
} 
performing this task and so a culture developed that said this was honorable work. ${ }^{72}$ Vawter also taught social responsibility via the school's code of disciplinary conduct. All students were expected to act honorably. Lying, cheating, and stealing were dealt with by a system of student monitors who enforced the discipline code. They investigated infractions and determined punishments. This was done in both the boy's and the girl's divisions at Miller Manual. This was a key part of Vawter's system of head, hands, and heart education. ${ }^{73}$

\section{The Education of Women}

Although Charles Vawter created a coeducational curriculum at the Miller School of Albemarle, not all Progressive Educators were in agreement regarding the education of women. With the Progressive Era's zeal to democratize society, many educators began to advocate for the admission of women into American colleges and universities and enroll them in the same curriculum as that available for men. Previously, women enrolled in higher education were limited to specific studies deemed to be feminine such as painting or music. However, after being admitted to universities such as the University of California at Berkeley or the University of Chicago, female students encountered significant hostility. Many educators held the view that women were prone to hysterical thinking which made them incapable of mastering the topics contained in the classical curriculum. Thus, the introduction of women into the student bodies of many colleges and universities was met with resistance by many male faculty, administrators, and students, who all felt their presence was a threat to the social order. Even at traditional women's colleges such as Vassar, the administrators were reluctant to change from the traditional gender specific studies. Furthermore, family members often made it difficult for

\footnotetext{
${ }^{72}$ Gray, Leslie's Weekly, 394.

${ }^{73}$ Vawter and Longley Literary Societies, Blue Ridge Blast (Roanoke: Stone Printing Co., 1905). 34.
} 
ambitious young women to pursue a liberal arts education. Traditional conservative values were an impediment, and this was especially pronounced in the South. ${ }^{74}$

When Charles Vawter was charged in the late summer of 1884 with creating a program for the education of girls at Miller Manual, he did his very best to create a successful program. An appeal had been made to the Board of Visitors to admit girls since Samuel Miller's will stated only that poor orphan white children would be admitted with no reference to gender. This appeal was followed by a legal request for the Circuit Court to rule whether or not Miller's will mandated the admission of girls. After asking the most prominent local attorneys to study the issue and make a recommendation, the Court in August of 1884 issued its verdict: the school should form two separate and distinct departments, and admit children of both sexes. ${ }^{75}$

In compliance with this order, a department for girls was authorized under the authority and control of Superintendent Vawter, and the first girl, twelve-year old Lillian Clay Goolsby was admitted on November 17, 1884. Thus, the Miller Manual Labor School was one of the first coeducational boarding schools in the United States. The daughter of a local saddle and shoemaker, Goolsby graduated from the Miller School in 1891 and later worked as a school teacher, secretary, government clerk, and even as a census verifier in Cuba. ${ }^{76}$

The development of a girls' department was in keeping with the changing culture of the American South in the late Victorian Era. Before the Civil War, in the South the literacy rate for women was the lowest in the nation. Only a few daughters of the white elite received an education outside of the home in private academies. What they studied was designed to assure

\footnotetext{
${ }^{74}$ Lynn D. Gordon, Gender and Higher Education in the Progressive Era (New Haven: Yale University Press, 1990), 189.

${ }^{75}$ Blue Ridge Blast 1905, Vol. 1, 32-33.

${ }^{76}$ Miller School Catalogue (Miller School, 1901), 48. Goolsby is commemorated on an obelisk found near the north steps of the Main Building of the Miller campus.
} 
male dominance and train the young lady to take pride in her subservient role. The curriculum consisted of what was often called the "ornamental arts" - music, painting, wax-working, and making fancy designs in needle-point, all of which would produce a vivacious adult who could adorn and ennoble her more aggressive husband. ${ }^{77}$

In the post-bellum period this cult of domesticity, which defined the woman's sphere as the household and children, was waning as women began to become involved in missionary work, temperance, teaching, and moral reform. Furthermore, the attributes of good wives gentleness, moral superiority, purity, and piety -- were needed in the public arena. Thus, to perform the aforementioned work required more than a primary education. This led to the development first of female and coeducational secondary schools, and ultimately to colleges and universities that educated women. The girl's department that Vawter created at Miller Manual was similar to the program that developed at the country's first coordinated college, Sophie Newcomb College in New Orleans, Louisiana, which was founded in $1886 .^{78}$

In 1884, Paul Tulane, a wealthy New Orleans merchant of French decent, donated his fortune to found an elite university so that southerners would not have to send their children to college in the north. ${ }^{79}$ Like Samuel Miller's will, the wording of Paul Tulane's bequest specified that the university he founded would be for "white youth" not "white males." Noting the gender ambiguity of the word youth, New Orleans women began the movement to gain access to Tulane University. This led a wealthy, widowed New Orleans philanthropist, Josephine Newcomb to endow the women's division of Tulane. She did so as a memorial to her daughter Sophie, who

\footnotetext{
${ }^{77}$ Amy T. McCandless, The Past in the Present: Women's Higher Education in the Twentieth Century American South (Tuscaloosa: University of Alabama Press, 1999), 6-7.

${ }^{78}$ Gordon, 166-167.

${ }^{79}$ Tulane actually made such a significant contribution to the University of Louisiana that the institution's name was changed to the Tulane University of Louisiana. Previously, the University of Louisiana had consisted of only a medical school but Tulane's gift enabled the creation of a full-fledged university.
} 
had died of diphtheria in 1870 at the age of fifteen. By the time Josephine Newcomb died in 1901, she had donated in excess of four million dollars to Sophie Newcomb College. ${ }^{80}$

Newcomb College was adjacent to Tulane but had its own campus and awarded its own degrees. However, Newcomb students shared the Tulane library and gymnasium and participated in the social life of the university. This arrangement was similar to that created by Vawter at Miller Manual. Miller girls had their own classes, their own dormitory quarters, and their own tables in the dining hall, but participated in the social life of the school through chapel, dances, and other extracurricular activities. Furthermore, both Newcomb and Miller girls were provided with many resources because both institutions had the funds to do so. Newcomb College was the one woman's college in the South that possessed a large endowment; in fact, Newcomb was the wealthiest independent college for women in the country. Finally, both Newcomb and Miller women studied a type of curriculum that developed during the Progressive Era. At Newcomb, Josephine Louise Newcomb requested that education should include not only study in the classical topics but also in topics pertinent to the "practical side of life." 81

Another southern college that was a pathfinder in the progressive goal of educating women was Agnes Scott College in Decatur, Georgia. It began as a seminary and high school in 1889 and evolved into a college. Named after the mother of a prominent military officer, George Washington Scott, the school's stated purpose was to teach the students what they called the Agnes Scott Ideal. This was accomplished by thoroughly qualified professors teaching a liberal curriculum modelled along the lines of that found at the "best institutions in the country." 82 At both Sophie Newcomb and Agnes Scott, the students received an education that combined

\footnotetext{
${ }^{80}$ Gordon, 168.

${ }^{81}$ McCandless, 31.

${ }^{82}$ Gordon, 169-172.
} 
characteristics of both male and female culture. This helped to push women's issues into the public arena, which led directly to the Nineteenth Amendment to the Federal Constitution. ${ }^{83}$

To conclude, the Progressive Era led to major changes in the way education was delivered and to whom it was delivered. School became much more welcoming to children; the students were taught in a more child centered manner by teachers who used new experimental methods such as the integrated curriculum and experiential learning. Furthermore, the role and the rights of women in both the secondary classroom and in institutions of higher learning changed significantly.

Nevertheless, there was one social group about whom many Progressive Educators had great reservations. Many progressives did not believe that African Americans were capable of higher order thinking. Thus, many progressives worked to merely train African Americans in disciplines traditional to the Antebellum Period. Topics such as domestic work, agricultural field work, and lower skilled factory work were the tasks the so-called White Architects of Black Education believed should be taught. There were some progressives who disagreed with this approach. They believed that all children can learn and that both Negroes and poor whites should have the opportunity to study the classical curriculum. The nature of this dispute will be described in Chapter Three of this study.

\footnotetext{
${ }^{83}$ Ibid, 188.
} 


\section{Chapter Three}

\section{Vawter on Race and Education}

When the Progressive Movement developed and began to control public debate, African Americans were hopeful that the liberal reforms sweeping the country would offer them some relief from the grim policies of the Jim Crow Era. Progressive activists pushed through antitrust acts, a progressive income tax, banking regulations, pure food and drug laws, and a host of other progressive policies that improved the lives of millions of Americans. These high-minded crusaders for justice felt compelled to reach out to the poor to help them achieve a fair chance of realizing the American Dream. However, these social advocates stopped short of helping all Americans. In particular, few social advocates were willing to help African Americans and other people of color.

In this chapter, I will describe how scientific racism was used by wealthy white industrialists and planters to severely limit the educational opportunities available to blacks. These so-called White Architects of Black Education had a controlling influence on what was taught at black colleges like Hampton and Tuskegee, and they used their power to weaken the private black universities such as Howard and Atlanta. Finally, I will explain how racist politicians in Virginia worked to emasculate the country's first state supported black university, Virginia State University in Petersburg, but were thwarted in their effort to do so by Charles Vawter.

\section{Scientific Racism}

This was a time when politics and the social sciences worked in tandem to suppress Negroes, Hispanics, and Asians. It was a period when white supremacists were supreme domestically, and imperialists suppressed people of color in America's new Caribbean and Asian 
colonial possessions. Many progressives were quick to adopt the beliefs of scientific racism. This was the belief that Negroes and other peoples of color were inherently inferior and thus deserved to be at the bottom of the social ladder. Many American governmental leaders believed in the pseudo-science known as eugenics. ${ }^{84}$ The intellectual background to the eugenics movement can be traced back to the Enlightenment. ${ }^{85}$

\section{The White Architects of Black Education}

It was this atmosphere that helped to create the type of educational reformers known as the White Architects of Black Education. Many of these men had made immense fortunes as a result of the Industrial Revolution. John D. Rockefeller, Andrew Carnegie, and Collis Huntington are examples of this type. Other architects were men who ran foundations for the aforementioned industrialists. Thomas Jesse Jones, Franklin Giddings, J. L. M. Curry, William Baldwin, and Robert Ogden are all important white architects who fall into the second category. These men were influenced not only by the inherent racism of their era but also by other factors.

Men like Ogden, Jones, and Curry wanted to transform Negroes into a useful labor source for the plutocrats of industry. Furthermore, the architects wanted to quarantine Negroes in the South for two reasons. They not only wanted to keep them available as a source of cheap labor for their wealthy southern planter friends, but they also wanted to prevent their migration to the North where their presence would be an irritant to the white public. ${ }^{86}$ The goals of the architects played a key role in the type of educational institutions and curriculums that developed during the Progressive Era. However, they met with resistance by the newly freed blacks.

\footnotetext{
${ }^{84}$ Retrieved August 12, 2016 from http://historynewsnetwork.org/article/1796

${ }^{85}$ Southern, 36.

${ }^{86}$ Watkins, 6.
} 
During the Anti-Bellum Era, it was illegal in the slave states to teach literacy to slaves. Thus, after emancipation the Freedmen wanted to be educated because they associated education with power. The educational leaders of the Freedmen in the South adopted the New England classical, liberal curriculum. The classical system of education did not make blacks feel inferior. Rather, it provided a means to understanding the world. ${ }^{87}$

Knowledge of the classics was the mark of an educated person and this was especially true in the South. Negroes were ambitious enough to prove that they were just as capable intellectually as white people, a development that threatened the white architects. This endangered white supremacy and contradicted the view that blacks belonged to a fixed subordinate position in society. ${ }^{88}$

The founding of Nashville's Fisk University in 1866, Raleigh's St. Augustine's University in 1867, Atlanta University in 1888, and other black institutions of higher learning endangered the white architects. They retaliated by using their financial power to weaken the aforementioned institutions and by making large donations to schools they favored such as Hampton and Tuskegee Institutes. Furthermore, one prominent architect, Thomas Jesse Jones, had very definite opinions regarding the education of Negroes. He believed that the future wellbeing of blacks rested with industrial education. ${ }^{89}$

\section{Armstrong and Hampton Institute}

Jones was a prominent supporter of both Samuel Chapman Armstrong and Booker T.

Washington. Armstrong founded Hampton Institute and Washington founded Tuskegee. After a successful career in the Union Army as an officer during the Civil War, Armstrong went to work

\footnotetext{
${ }^{87}$ Anderson, 28-30.

${ }^{88}$ Fairclough, 149-151.

${ }^{89}$ Watkins, 114.
} 
as a general in the Freedmen's Bureau and was assigned to Hampton, Virginia to deal with the thousands of freed Negroes who were destitute in the Virginia Peninsula. ${ }^{90}$

Armstrong had long dreamed of establishing a school that could train Negroes to work as teachers among their own people - teachers who should be leaders of their people towards better moral, physical, and mental habits. Armstrong, with the help of the American Missionary Association, established what came to be known as Hampton Institute in $1867 .{ }^{91}$ Armstrong believed in the concept of mind, hand, and heart education. There is no doubt that head, hands, and heart education was in vogue, however, not all educators were in agreement that it was suitable for the Negro. The hands part was acceptable to white progressives, but they had problems with the head component. Most southerners did not want black leaders who challenged accepted societal norms. ${ }^{92}$

Armstrong believed that industrial education would prevent the school from producing students with no sense of self-help or independence. ${ }^{93}$ This type of educational philosophy was close to Vawter's belief that "many know but few can do." Unfortunately, history would prove Armstrong rather naïve in his belief that southern whites would take an interest in the education of blacks.

Armstrong faced another problem very similar to one Vawter dealt with on a daily basis. Both poor whites and Negroes lived in a society that denigrated them; most were brought up believing that they had little chance to succeed because they were incapable of success. It was

\footnotetext{
${ }^{90}$ Edith Armstrong Talbot, Samuel Chapman Armstrong: A Biographical Study (New York: Doubleday, Page \& Company, 1904), 164. It is interesting to note that after Armstrong had accepted the American Missionary Association's (AMA) offer to direct Hampton Institute, his commanding officer, General Oliver Howard, offered Armstrong the position of president of Howard University. Armstrong was flattered but declined the offer because he had accepted the AMA's offer and he was a man of his word.

${ }^{91}$ Ibid, 148-156.

92 Ibid, 150.

${ }^{93}$ Washington, 12.
} 
the task of Vawter, Armstrong, Washington, and other educational leaders to change this attitude in the students they mentored. ${ }^{94}$

Although Armstrong had a general desire to help the Negroes, like many progressives he also harbored racial prejudices. He held a number of stereotypical beliefs about blacks. He wrote that the major problem for African Americans was their laziness, or what he called their "shiftless propensity." 95 The contradictory nature of Progressive Educators can be clearly seen in Armstrong. Despite his racial prejudices, he had a special relationship with his star pupil Booker T. Washington. In forming this unique relationship, Samuel Chapman Armstrong demonstrated that he was not an ordinary late nineteenth-century white American. He made a black man his spiritual heir and the bearer of his vision for the people to whom he had chosen to dedicate his life. Booker T. Washington was unable to define his own path until after Armstrong's death, but when he began to do so his course proved much more precarious than that of his white mentor. Washington's color, and the resurgent tide of racism at the turn of the century, made his rise to leadership and prominence a balancing act even more delicate than the one Armstrong had performed for the preceding twenty-five years. Armstrong devoted his life to black uplift. His weakness was his rigid outlook. ${ }^{96}$

It would be a mistake, however, to brand Armstrong as a someone without redeeming value. Armstrong's curriculum for Hampton in 1868 was commendable and appropriate for the needs of Virginia's Negroes in the years immediately following emancipation. The major fault in Armstrong's design was its static nature. He didn't foresee that Negroes would advance much faster than he thought was possible, and he didn't realize how the white establishment would

\footnotetext{
94 Ibid, 183.

${ }^{95}$ Donald Spivey, Schooling for the New Slavery: Black Industrial Education, 1868-1915 (Westport, CT: Greenwood Press, 1978), 8 \& 25.

96 Engs, 139.
} 
bring on a resurgence of racism. In general, he never reconsidered and modified his founding principles. ${ }^{97}$

To operate his institute, Armstrong had to accommodate a wide range of constituencies: unreconstructed rebels who were opposed to all forms of education for Negroes; southern white moderates who recognized that education for blacks was necessary; southern power brokers who viewed black education as the pet projects of rich and fanatical Yankees; and black critics who wanted classical education to be inserted into the curriculum. Armstrong's number one goal was to serve his students, but to do so he had to come to terms with these disparate groups. ${ }^{98}$

To meet this challenge, Armstrong restructured his board of trustees to include numerous wealthy industrialists. One, Collis Huntington, was typical of the type of white architect of black education that Armstrong appointed to the Hampton Board. Huntington stated that it was his belief that " ... training the Negro could be a benefit only if it were kept within narrow limits. The brightest of them ... could only learn trades and thereby have a means of lifting themselves out of the ranks of unskilled labor." ${ }^{\text {99 }}$ Armstrong was not successful in thwarting the wishes of these white architects.

\section{Washington and Tuskegee Institute}

One of the many African Americans helped by Armstrong was Booker T. Washington, who left Hampton to found and operate a similar school, Tuskegee Institute. There Washington encountered many of the same difficulties as Armstrong. He too had to develop relationships with wealthy northern industrialists while accommodating southern bigots, white moderates, and Negroes who wanted Tuskegee to teach the classical curriculum. ${ }^{100}$

\footnotetext{
97 Ibid, 85.

${ }^{98}$ Ibid, 144-145.

${ }^{99}$ Ibid, 156, 167.

${ }^{100}$ Washington, v.
} 
Washington's educational goals were remarkably similar to those espoused by Charles Vawter. At Tuskegee, students were expected to learn the dignity of labor while being taught the trades in a thorough and effective manner. Tuskegee graduates would then supply the demand for trained industrial leaders. Also, Tuskegee assisted her students in paying all or a part of their expenses, which was similar to what was done at the Miller Manual School. ${ }^{101}$ Vawter's students, however, did not have to confront racial prejudice, but like the Tuskegee students they did have to face occupational discrimination. Washington summarized the situation clearly in stating, "There is nothing harder to overcome than an unreasonable prejudice against an occupation or a race. The more unreasonable it is, the harder it is to conquer." ${ }^{102}$

Washington also preached from the same theme as Vawter in making the case that the South needed to help the downtrodden advance themselves. Washington in his famous speech at the 1895 Atlanta Cotton States and International Exposition made the same argument that Vawter outlined in his 1899 speech before the Virginia Mechanic's Institute. Vawter spoke of the plight of the poor whites in the South, whereas Washington made the case that unless whites helped uplift the Negroes, black poverty and ignorance would act as a constant drain on the South's resources and social progress.

The white schoolmen, however, put a white-supremacist spin on industrial education - it was to be the first and last element of Negro education. Unlike the Miller Manual School, where traditional, classical education was a valued component of the educational experience, the white educators believed that there should be few books in the black industrial school. Lessons would be practical rather than academic. Even the educational terminology was loaded with meaning-

\footnotetext{
${ }^{101}$ Ibid, 80-81.

102 Ibid, 109.
} 
blacks were "trained" not "educated." This would prepare them for careers in the field, shop, or household, the only careers the white establishment deemed suitable for the Negro. ${ }^{103}$

\section{The Washington - Du Bois Conflict}

Booker T. Washington faced other opponents than the prejudicial white schoolmen. He also drew criticism from other Negro educators, in particular from William Edward Burghardt Du Bois. Du Bois was one of America's leading intellectuals and was the first black man to receive a doctoral degree from Harvard. He worked for many years as a distinguished professor of sociology at Atlanta University and published a number of scholarly books.

Du Bois objected to Washington's emphasis on industrial training as the only means for black education. Du Bois believed this consigned the Negro to the perpetual status of manual laborers. He felt that a better strategy was to identify the "Talented Tenth" and train them through education to lead the rest of the race to better opportunities and political representation. Du Bois argued that the focus on industrial education at the expense of higher education had born tainted fruit - disfranchisement, the rise of segregation, and the removal of funding from black universities that offered a classical curriculum. ${ }^{104}$

Du Bois was convinced that liberal arts education should be at the core of the curriculum in order to ensure that the student developed the higher order thinking skills needed to understand the rapidly changing world. Du Bois and Charles Vawter were alike is this educational belief - a belief that sets them apart from the majority of progressives who, under the influence of the northern philanthropists, attempted to remove liberal arts from the curriculum and provide only industrial education. Moreover, Du Bois was flexible in his thinking and he adjusted his educational philosophy for the advancement of Negroes as conditions changed, but

\footnotetext{
${ }^{103}$ Fairclough, 148.

${ }^{104}$ Moore, 71-72.
} 
without deviating from his belief that a sound education should be a broad education for the "mind and the hand." 105 Throughout his long career Du Bois was “... adamantly opposed to technical or practical education that was separated from liberal education." ${ }^{106}$ In calling for this approach in the classroom, it can be seen that like so many other progressives, Du Bois was a pragmatist who believed that children should have both “...experiential education and education in the humanities." 107

Like Vawter, Chapman, and Washington, Du Bois believed that the South's greatest problem was its "...abysmal economic status and failure to engage in economic development." He consistently urged southerners to educate both the white and the black working classes, and stated that the future economic success of the South was dependent on both granting of political rights and the type and quality of educational opportunities provided to the working classes. ${ }^{108}$

\section{Virginia State University and Vawter's Work with African Americans}

Vawter was a product of his time and place, thus it is likely that he shared many of the racial prejudices that were commonly held by white society. However, Vawter was not one of the "White Architects of Black Education." This is evident when his role at Virginia State University (VSU) in Petersburg is examined. Vawter was the Rector of the VSU Board of Visitors from 1902 until his death in 1905. Although Vawter's tenure in Petersburg lasted only a few years, he played an important role. To understand the work Vawter performed for VSU, it is necessary to first set the historical context. ${ }^{109}$

\footnotetext{
105 Alridge, 104.

106 Ibid, 65.

${ }^{107}$ Ibid, 42 \& 79.

108 Ibid, 27.

109 Toppin, 50.
} 
Lincoln University in Pennsylvania and Wilberforce University in Ohio are the first two historic black colleges that were founded and chartered before the Civil War, the former in 1854 and the latter in 1855. But with the end of the war dozens of new black colleges were founded, for example Hampton Institute, Howard University, Fisk University, and Tuskegee Institute. All of these schools, however, were private schools that were founded by either the Federal Freedmen's Bureau, various religious denominations, or private foundations. There were a few state-supported schools of higher education established in the post war era for Negroes, but they were either two or three-year certificate-awarding institutions. VSU has the distinction of being the first state supported, four-year black college founded in the United States. Originally known as Virginia Normal and Collegiate Institute (VNCI), the college was chartered by the Virginia General Assembly on May 6, 1882 and opened in 1883. ${ }^{110}$

The VNCI charter stated that the school was "...to be used exclusively for the education of colored people," and that the "professors and teachers...should be colored." Furthermore, the charter stipulated that six of the seven members of the board of visitors should be "...wellqualified colored men." An ex officio board member would be the Virginia State Superintendent of Education, who was white. This made VNCI quite different from other Progressive Era black colleges like Hampton and Tuskegee whose board members were white males. ${ }^{111}$

Virginia's support for VNCI was comparable to that provided for white schools like the University of Virginia and Virginia Military Institute. The legislature ear-marked \$100,000 from the sale of publicly owned railroad stock to finance the purchase of the school's site and the construction of the school's buildings, and it appropriated $\$ 20,000$ annually to help operate the college. Putting the college under black control and placing these substantial state funds in the

\footnotetext{
${ }^{110}$ Ibid., 3-5.

${ }^{111}$ Ibid., 13.
} 
control of black men was a radical step in the early 1880s, a step no other state had been bold enough to make. It is doubtful that such bold action would have been taken if it were not for the work of Alfred W. Harris. ${ }^{112}$

Harris was born in 1854 into a family of free blacks who had lived as freepersons in Prince William and Fairfax Counties since the 1770s. Harris attended Alexandria's public schools and went on to receive a law degree from Howard University in the late 1870s. He then started his law practice in Petersburg and lived in nearby Dinwiddie County. He was elected to represent Dinwiddie in the Virginia House of Delegates, where he served until 1888. Harris used his position as a leading member of the Readjuster Party to lead the fight to establish VNCI. ${ }^{113}$

\section{Political Infighting in Virginia}

The Readjusters were led by the former Confederate General William Mahone. Mahone, a railroad baron, entered politics to fight to keep public schools fully funded, a position that endeared him to blacks who saw education as a means to racial uplift. The Readjusters were opposed by the Funders, who were mostly Conservative Democrats who wanted to pay off Virginia's debt as quickly as possible. The Funders planned to cut the state's budget for public education to appropriate the funds necessary for debt reduction. In the years before the adoption of Jim Crow Era disfranchisements, many black Virginians could vote. The Readjusters appealed to these Negro voters by promising to support both public schools and the establishment of a state college to train black teachers. These proposals proved popular enough for the Readjusters to gain control over both the General Assembly and the governorship in the

\footnotetext{
112 Ibid., 13.

113 Ibid., 13.
} 
elections of 1879 and 1881. These political victories enabled Alfred Harris to introduce and push through the legislature the bill that chartered VNCI in March of $1882 .^{114}$

Harris' bill provided for both a three-year Normal (teacher training) program and a fouryear liberal arts college. Article VII of Harris' bill stated that, "In the said institute there shall be a Normal Department, in which shall be taught such branches as are usually taught in the best normal schools in the country; said branches to be prescribed by the visitors of said institute provide that such Normal courses of instruction shall not be longer than three years." Article VIII of the bill provided for the collegiate department: "There shall be connected with said institute, a College, and such professional departments as the board of visitors may think expedient and proper, for the higher education of colored persons. In the College Department, shall be taught the classics, the higher branches of mathematics, and such other branches as are usually taught in colleges...."115 Thus the VNCI curriculum was very different from what either Samuel Clayton Armstrong or Booker T. Washington developed at their respective institutions. Harris had to use all of his powers of persuasion to push to passage the collegiate provisions as well as the stipulations that VNCI be under black administrative control. He also fought diligently for the entire faculty to be staffed by Negroes as he explained in a legislative debate on the topic: "...a white person who does not associate with or at all mingle with the colored people cannot possibly have any interest in the intellectual advancement of the colored race....He mingles not with the families whose children he is to instruct, and therefore does not know and cannot know their wants or the means which would most readily make them zealous in the pursuit of knowledge." "116

\footnotetext{
114 Ibid., 13.

115 Ibid., 13.

116 Ibid., 14.
} 
Harris not only sponsored VNCI in the General Assembly but also helped with the school's operations during the critical early years. It is important to recognize, however, that it is unlikely that Harris would have been successful in his quest without the support of the leader of the Readjuster Party, former Confederate General William Mahone. Most certainly, the creation of VNCI as both a normal institute and as a college was a source of pride to Negroes in Virginia and elsewhere who viewed both a teaching career and a college education as paths to a better life for both themselves and their race. ${ }^{117}$

After the March 1882 passage of the charter, VNCI did not open for operation until nineteen months later due to a lawsuit brought by the Funder Party challenging the allocation of state funds for a Negro institute instead of debt reduction. After the suit failed, the VNCI Board of Visitors held their first meeting in February of 1883. The original board, true to Harris' legislation, consisted of six black members and one white visitor. Over the next six months, the board purchased land with buildings for the school's site, selected the school's faculty and administration, and attended to all of the details necessary for VNCI to open on October 1, 1883 with an enrollment of sixty-two students; before the end of the school-year, the enrollment had increased to $131 .{ }^{118}$

\section{The White Architects Move to Emasculate Virginia State}

Virginia politics quickly had a deleterious effect on VNCI. As the Readjuster Party declined, the Democrats began to change the way VNCI operated. One of the most significant changes concerned the composition of the Board of Visitors. The legislature began to ignore the institute's charter and appoint increasing numbers of white Democrats to the seven-member board. Subsequently, the board began to make demands of the VNCI administration. For

\footnotetext{
117 Ibid., 13-16.

${ }^{118}$ Ibid., 17.
} 
example, the board demanded that the curriculum include specific industrial arts such as sewing, brick masonry, and carpentry while simultaneously reducing VNCI's annual operating budget.

These new board members then moved to degrade the curriculum of VNCI and remove classical courses like Greek and Latin from the curriculum. They were aided by political events. In 1890, Fitzhugh Lee's term as governor ended. Lee was respected by black Virginians for his moderation and fairness. He was succeeded by a reactionary Democrat, Philip W. McKinney. McKinney's State Superintendent of Public Instruction, John E. Massey, was even more radical than the governor. ${ }^{119}$

Massey proposed that either VNCI's college department be eliminated or that the school should be closed. McKinney then replaced VCNI's biracial board of trustees with an all-white board. McKinney's actions set a pattern that lasted for decades; all of VNCI's board members were white from 1890 until 1964. One of McKinney's new white board members was John E. Massey who was made chairman. Massey complained that black students were “... learning, or pretending to learn, Latin, Greek, and chemistry. I think it is time for that sort of nonsense to stop." 120

A fellow board member, Paul C. Campbell of Amherst County, who was on record of being in favor of abolishing VNCI, stated that when he had visited VNCI he "...saw Negro scholars in luxuriously equipped quarters and lecture rooms...." Campbell stated: "I think it important to convert the Normal School building into a supplemental lunatic asylum and let the money now wasted on the school be appropriated for the care and maintenance of lunatics."121 Thankfully, this proposal went nowhere. Meanwhile, in his desire to transform VNCI

\footnotetext{
119 Toppin, 51-53.

${ }^{120}$ Fairclough erroneously attributes these remarks to Vawter. See also Toppin, 51-53.

121 Toppin, 51-53.
} 
into a copy of the Hampton-Tuskegee model, Massey pressed VNCI to replace the classical curriculum with cooking, sewing, and other industrial courses. After he was successful in pushing through these changes, Massey boasted, "We took out all that Latin, Greek, and Hebrew." 122 The state further mandated that all students be required to take classes in either domestic science or manual training. This reduced the institution to little more than a glorified high school. ${ }^{123}$

John Massey's influence on VNCI was particularly negative because he remained Superintendent for eight years, as he was retained by McKinney's successor Governor Charles T. O'Ferrall. Massey publicly stated: "I am tired of seeing white men taxed to educate Negroes who show their ingratitude by arraying themselves against us at every election.” Massey proposed a new tax scheme - taxes paid by whites would be used to educate white children, while black schools would only be supported by taxes paid by blacks. Luckily this proposal died in the Assembly. ${ }^{124}$

Massey was very public about his feelings. At the 1891 graduation ceremony, Massey told the assembled students that "slavery was a blessing." Massey's successor as State Superintendent was cut from the same cloth. Joseph W. Southall, who served from 1898-1906 under both Governors Tyler and Montague, believed that Virginia was doing a disservice to the Negro by giving him “... a smattering of book knowledge that tends to educate him out of his

\footnotetext{
${ }^{122}$ Fairclough also erroneously attributes this statement to Vawter. See also Toppin, 51-53.

123 Toppin, 51-53. See also Fairclough, 168. Fairclough states that Vawter was the board member who took the actions to eliminate VNCI's collegiate classes and made the boasts I attribute to Massey. As both Virginia State University Professor of History Edgar Turpin and Archivist Lucious Edwards document that these actions were actually the work of Massey, and as there is no evidence in his speeches or letters of Vawter using highly charged race-baiting language, I am of the opinion that the British historian Fairclough was careless in his research. It is logical to conclude that Toppin and Edwards are in a better position to assess what happened at Virginia State University at the turn of the Twentieth Century. Moreover, there is discrepancy in Fairclough's use of dates. Fairclough states that the name change from VNCI to Virginia Normal and Industrial Institute occurred in 1887 when, in fact, that change did not occur until 1902.

${ }^{124}$ Ibid., 51-53.
} 
environment rather than to make an honest living and becoming a good and profitable servant." Southall further stated that educating a Negro made, “...him dissatisfied with the menial pursuits in which his fathers were engaged, and in which he must engage...." Southall, like so many other educators of his era, believed that the only path for the Negro was through moral and industrial training. In his Virginia School Report for 1899-1900, Southall cited both the Miller Manual School of Albemarle and Hampton Institute as prime examples of such beneficial training. ${ }^{125}$

\section{The Petersburg College is Renamed Virginia Normal and Industrial Institute}

The turn of the Twentieth Century is an important period in the History of Virginia State University. In 1901-1902, Virginia held a constitutional convention and wrote a new state constitution. The main goal of the convention was the Democratic Party's aim to disenfranchise as many black voters as possible. With the new constitution in place and with little possible black political push-back, the General Assembly changed the charter of the school. The state renamed VNCI Virginia Normal and Industrial Institute (VNII) by removing the word "collegiate" from the title, an action that was deeply hurtful to the Negro population of Virginia and beyond. The new charter of March 29, 1902 stated that: "The said school shall be known as the Virginia Normal and Industrial Institute, and shall embrace a Normal Department and an Industrial Department, and also such other departments as may be deemed expedient and proper." 126

\section{Vawter's Appointment as Rector of the Virginia State University Board}

Southall's support for Miller Manual may have played a role in Governor Montague appointing Charles Vawter to the board as rector in 1902. Interestingly, Vawter was well

\footnotetext{
125 Toppin, 53.

126 Ibid., 50-55.
} 
thought of by the Virginia State University Professor of History, Edgar Toppin, and by the University Archivist Lucious Edwards. In their work, Loyal Sons and Daughters: Virginia State University, 1882-1992, Toppin and Edwards state that Vawter played a key role in keeping the institute in operation by using his expertise in manual training to help the school make the transition to industrial training when the collegiate program was abandoned. ${ }^{127}$

The VNII student body was disdainful of men like Southall and Massey, but showed goodwill towards Vawter. Perhaps that is the reason that the third major building constructed on the Virginia State University campus was Vawter Hall, which was constructed in 1908 three years after Vawter's death. Vawter Hall was the first building constructed solely for classroom use and was where the school's industrial classes were taught. Today, after many changes in use, Vawter Hall remains one of the two oldest buildings on the campus. ${ }^{128}$

\section{Vawter Ignores the Mandate of the White Architects}

Furthermore, the minutes of the VNCI Board of Visitors show Vawter in a very different light from that painted by Fairclough in his 2007 study A Class of Their Own: Black Teachers in the Segregated South, in which he describes Vawter as the chief player in emasculating VNCI's classical curriculum. The minutes of May 14, 1902 show that Vawter quietly worked to keep certain aspects of the VNCI classical curriculum despite the orders of the State Superintendent of Education.

As described in Chapter One of this study, Vawter led the board to decide that although Latin had been taken out of the curriculum, those students who had begun their study of the language could continue with said study. The board and Rector Vawter also decided to establish

\footnotetext{
127 Ibid., 55.

${ }^{128}$ Ibid., 50, 56. See also, "Minutes of the Board of Visitors", Virginia Normal and Collegiate Institute No. 1(Virginia State University), 30-34.
} 
two-year courses for the following academic disciplines: Latin, mathematics, chemistry, and architectural design. Students who completed such programs would then receive a special diploma. $^{129}$

Vawter's support for the study of Latin is at odds with pragmatists like Thorstein Veblen who viewed the study of classical languages as "useless" and "wasteful."130 Here we can see that Vawter had a very different view of the ability of Negro students than the beliefs held by other progressives like Thomas Jesse Jones, Franklin Giddings, J. L. M. Curry, William Henry Baldwin, and Robert Ogden. Finally, Vawter and the VNCI board maintained the institute's architectural design program despite the mandate of the General Assembly and the State Superintendent to abolish such a curriculum. Then at the meeting in May of 1903, Vawter and the board voted to raise the salaries of the engineering professors. ${ }^{131}$ All of this was done quietly; nevertheless, it is likely that it was only because of Vawter's prestige that the General Assembly did not intervene. Perhaps Vawter believed that Negroes were inferior to the white race, but his actions to preserve the right for blacks to study classical languages, architecture, and engineering at VNCI marks him as a very different type of white, progressive educator. Unlike the white architects of black education, Vawter trusted in the ability of blacks to master these subjects.

These same minutes also show that Vawter, as he had done at Virginia Tech, used his relationship with Thomas Edison to build a power plant, install dynamos, and light the institute with electricity. Vawter then spent his own money to negotiate with the Peabody Fund to secure

\footnotetext{
129 "Minutes of the Board of Visitors," Virginia Normal and Collegiate Institute No. 1(Virginia State University), 30-34.

${ }^{130}$ Thomas Fallace, Dewey and the Dilemma of Race: An Intellectual History, 1895-1922 (New York: Teachers College, 2011), 31 .

131 "Minutes of the Board of Visitors," Virginia Normal and Collegiate Institute No. 1(Virginia State University), 30-34.
} 
the money needed for the electrical work. ${ }^{132}$ This progressive development was hardly the work of a man who was in agreement with the world view of Massey and Southall. Rather, it is clear that Vawter believed that all of Virginia's students, both black and white, deserved a chance to better themselves and to contribute to the reconstruction of Virginia after the devastation of the Civil War. Indeed, Vawter was so liked by the VNCI community that after his death in September of 1905, the VNCI board resolved that the students and faculty “... recognized in him [Vawter] a steadfast friend and advisor." ${ }^{.133}$ The board then declared that “... the new [industrial] building will in the future be known as the 'Vawter Industrial Building." "134

Vawter's work at both Miller Manual and Virginia State show that he, unlike many other progressives, believed that all people can learn. His record shows that he believed this to be true for both poor whites and Negroes. His work also shows that he, like Du Bois and Dewey was an advocate of using both the classical curriculum and training in crafts that involve using the hands to make a skilled product. The tension that distinguishes the lives of many progressives between adherence to democratic opportunity and racial prejudice appears to be absent in Vawter's life.

\footnotetext{
${ }^{132}$ Ibid., 45.

${ }^{133}$ Ibid., 49.

${ }^{134}$ Ibid., 57.
} 


\section{Chapter Four}

\section{Vawter on Industrial vs. Liberal Education}

In the last decades of the nineteenth century a number of debates developed regarding who should be educated and what form of education should be delivered. Titans of industry -moderates, liberal supporters of civil rights, racists, and a number of other groups -- all had opinions concerning education. The titans of industry were interested both in developing a large supply of cheap labor for their factories, mines, and plantations and in keeping blacks

quarantined in the South. Racists wanted to limit Negroes to the occupations of the Ante-Bellum Era, while moderates and liberals wanted to expand the opportunity to achieve the American Dream to all members of society including Negroes and poor whites.

Some believed that certain socio-economic groups were incapable of mastering a curriculum which called for higher order thinking. They believed that Negroes and poor whites should only receive training for industry. Men like Andrew Carnegie, Thomas Jesse Jones, Robert Ogden, Collis Huntington, and Samuel Armstrong supported this view. This was also the position taken by the American Missionary Association as well as a number of other foundations. Whereas other progressives believed that all students should have the opportunity to study the classical curriculum of mathematics, foreign languages, literature, the laboratory sciences, and history. Men like John Dewey, W. E. B. Du Bois, and Charles Vawter held this belief. Furthermore, there was debate concerning what form industrial education should take. As described earlier in this study, the supporters of industrial education held views that were different from those who believed in manual training.

In this chapter, I will describe and discuss the differences between liberal and industrial education. Additionally, I will show that in the Progressive Era many institutions implemented a 
curriculum that offered an alternative. Charles Vawter at the Miller Manual School created and directed a manual labor program; such programs combined the classical curriculum with experiential work in the skilled crafts such as working with electricity. Vawter provided the white students at Virginia Polytechnic Institute and the Negro students at Virginia State with similar classroom and shop floor instruction in electricity and other crafts. In so doing, Vawter was different not only from progressives like Armstrong and Washington, but also from white architects who favored industrial education for blacks and poor whites like Rockefeller and Curry. I will conclude this chapter by describing the criticisms of manual training education and an explanation for its decline at the end of the Progressive Era.

Industrial education, as practiced in the nineteenth century, taught useful skills to the classes of people whom the dominant white oligarchs deemed inferior. This included the children of the poor, the deaf and the blind, the retarded, and Negroes. Its goal was to transform these marginalized groups into docile workers by the time they reached adulthood so that they would not become disaffected and dangerous. There was also a fear that if not placated, these groups would become supporters of communist and anarchist agitators.

Industrial education did not have an element of social mobility. On the other hand, manual training education in higher education developed as a way to provide healthful exercise and financial support for students of a higher social stratum in American society. These were students who were simultaneously studying the classical curriculum. Numerous colleges and universities experimented with manual labor education. Thus, manual labor education did contain an element of social mobility. ${ }^{135}$

${ }^{135}$ Engs, 79. 


\section{Industrial Education}

As stated, the American Missionary Association (AMA) was an early supporter of industrial education. In June of 1866, Armstrong proposed that the AMA finance the purchase of land necessary for the founding of a school that would train the Freedmen and Freedwomen in the art of making cloth. Armstrong was convinced that blacks needed a rigid, disciplined educational environment. Furthermore, Armstrong and the AMA viewed blacks as a "backward race of peoples" for whom the only appropriate form of education was elementary and industrial education. Armstrong and the AMA believed that the South's future would be agricultural. Therefore, a premium should be placed on training men skilled in modern agricultural methods and the repair of agricultural machinery. ${ }^{136}$ In this, Armstrong held a very different view from Vawter who believed that the South's future depended on training students in the physical sciences. Vawter believed such training was necessary both to repair the physical destruction of the Civil War and to enable the South to industrialize.

Armstrong's preference for industrial education was reinforced by his donors. In addition to the AMA, industrialists like Huntington began to give tens of thousands of dollars to Armstrong's Hampton program. Huntington was part of a new coalition of wealthy men from both the North and the South who viewed industrial training as the appropriate vehicle for black economic and social containment. These men believed training Negroes must be kept within narrow limits. They were firm believers in scientific racism and believed it to be folly to try to give blacks a formal education. ${ }^{137}$ Perhaps J. L. M. Curry, a leading advocate of industrial education, stated best the goals of the supporters of industrial education: "The Negro could be

\footnotetext{
${ }^{136}$ Ibid, 73-78.

${ }^{137}$ Ibid, 156.
} 
both Christianized and educated, and that upon his Christianization and his right education [industrial training] rested ... the safety and prosperity of the white race with whom he dwelt."138

In reality, there was little industrial education that was taught at either Hampton, Tuskegee, or a number of other industrial schools. At Hampton, the male students worked at various types of unskilled tasks for their first year while learning rudimentary elementary subjects for two hours each evening. ${ }^{139}$ The immediate post bellum period was a time when a shortage of domestic servants developed in the North as the Irish, who had previously filled this need, began to move into the expanding factory jobs. The training in dusting, making beds, and cooking that Armstrong's female students received made them perfect for this employment. ${ }^{140}$ Armstrong considered training blacks beyond this type of work to be a waste of time, thus he was adamantly opposed to institutions like Fisk, Howard, and Atlanta, schools where the classical curriculum was taught. ${ }^{141}$

Hampton served as a model not only for Tuskegee but for other institutions as well. Some of the most strident racists praised the Hampton model and called for its copy across the South. However, there were a number of blacks who were opposed to Hampton's program. W.E. B. Du Bois was one but another was William Roscoe Davis. Davis was born a slave in Norfolk but obtained his freedom. Later, when he returned to Hampton and saw what Armstrong was delivering to his students, Davis remarked: "If Negroes don't get any better education than Armstrong is giving them, they may as well have stayed in slavery." $" 142$

\footnotetext{
138 Spivey, 28.

139 Ibid, 20.

140 Ibid, 22.

${ }^{141}$ Ibid, 26.

142 Ibid, 36.
} 
Armstrong's successor and star pupil, Booker T. Washington, preached that industrial training was superior to academic education. Washington did believe that some blacks should be trained in the arts and the professions, but he felt that this type of education was financially beyond the means of most Negroes and lacked the best chance for black uplift. He believed that industrial education would create a Negro labor force the South would come to depend upon. This in turn would help reduce racism and bring about more harmonious relations between the whites and blacks. ${ }^{143}$

Washington's curriculum was almost exclusively industrial and the few academic subjects offered were optional. Washington's goal was to matriculate Negroes that the white public valued. Therefore, the Tuskegee students' training was primary in how to behave rather than how to acquire the skills needed to be a craftsman. The faculty members who complained about this lack of academic emphasis were either marginalized or terminated. The elementary nature of the Tuskegee program meant that when students transferred in from schools like Fisk or Atlanta, they were placed in the senior ranks, whereas, as noted in an earlier chapter of this study, few Tuskegee undergraduates who were schooled entirely under Washington's tutelage could read the Bible or lay a brick. ${ }^{144}$

Thus, both Armstrong and Washington held very different views than Charles Vawter regarding the proper form of education for African Americans. At Virginia State, Vawter helped implement a curriculum of both classroom and hands-on training in the developing field of electrical engineering as well as classical studies such as architecture and Greek and Latin. In this sense, Vawter treated black Virginia State students just as he did the poor white children at

\footnotetext{
${ }^{143}$ Ibid., 51.

${ }^{144}$ Ibid, 54-57.
} 
Miller Manual; at both institutions, he combined the classical curriculum with training in the skilled crafts.

The overriding goal of the class of rich planters and industrialists who supported both Hampton and Tuskegee was to rebuild the way of life that existed before the Civil War by building a new southern community on the remnants of the Old South. They hoped to have the social, cultural, and political values of the Old South superimposed on the needs and policies of the Industrial Revolution. The Hampton-Tuskegee model would help achieve this result and also serve the northern capitalists who owned the entire southern railroad system, as well as the South's mines, steel mills, cotton plantations, and numerous other operations. ${ }^{145}$

All of these industries used the cheap, compliant, and reliable black labor that Hampton and Tuskegee trained. ${ }^{146}$ The claim that true industrial arts were taught at both Hampton and Tuskegee was more propaganda than reality. In fact, the only schools that really taught high level industrial skills were located in northern manufacturing centers; the New York Trades School, which is described later in this chapter, was one such example. By the end of World War One, it had become clear to black students and their parents that the industrial school model was a failure; instruction was poor and the curriculum was designed to train Negroes to be subservient. ${ }^{147}$

\section{Arguments for Liberal Education}

One of the leading critics of the Hampton-Tuskegee system of industrial education was W. E. B. Du Bois. Du Bois argued that black racial uplift could be best achieved by giving the most exceptional black males a superior liberal education. ${ }^{148}$ This "Talented Tenth" would need

\footnotetext{
145 Ibid., 54.

146 Ibid, 76-77.

147 Alridge, 75.

${ }^{148}$ Here we can see an element of the male chauvinism characteristic of the late nineteenth century.
} 
to understand the challenges that are presented by a rapidly changing world where the technological advances of the Industrial Revolution were transforming society repeatedly. A narrow vocational education cannot give one the independence of judgement necessary to understand broad societal change and thus provide the leadership needed for a downtrodden race. $^{149}$

Du Bois also argued that a liberal education provided students with the means to understand their own background and how their place in the world had come to pass. To that end, Du Bois argued that African and Afro-American histories and other racially related social science studies should be part of the liberal curriculum. This would not only help the Negro students understand their world but it would also help prevent feelings of inferiority, which the oppressive Jim Crow Era culture promoted. Nevertheless, Du Bois was not opposed to industrial education. He saw the need for students to be taught the skills to make a living, he just did not believe industrial instruction should be separated from a broad liberal arts education. He called for a synthesis of the two as the best route towards black uplift. ${ }^{150}$

Du Bois' arguments have been echoed by more recent observers. In his volume of philosophical lectures entitled Science and the Modern World, published in 1925, Alfred North Whitehead argued that the rapid pace of change was making it difficult for students to adapt and know their place in the world. Whitehead wrote that the decline in general knowledge and corresponding increase in specialized knowledge was making it increasingly difficult to understand change. ${ }^{151}$ John Dewey made a similar argument in Schools of To-morrow.

\footnotetext{
149 Alridge, 61-64.

${ }^{150}$ Ibid, 63-65.

${ }^{151}$ Alfred North Whitehead, Science and the Modern World (New York: Macmillan, 1925), 86.
} 
The President of Dartmouth College, James O. Freedman, in his study Liberal Education and the Public Interest, bemoaned the move towards specialized education, something he called premature vocationalism. He argued that the loss of classical learning resulted in an indifference to the history that has transpired before our own time and this meant a loss of perspective. He posited that a liberal education made one independent in judgement, skeptical of authority and of all dominant modes of thinking, and promoted an inner sense of self-worth. Additionally, Freedman wrote that liberal education promoted reflection, humility, hospitality towards points of view other than one's own, an openness to constructive criticism, and a belief in science and the natural world. Freedman went on to say that liberal education wasn't perfect but it did have the potential to help us see the world clearly. ${ }^{152}$

In regards to Du Bois' view that educational administrators should synthesize a broad liberal arts curriculum with hands-on instruction in the skilled crafts that can earn one a living, just such a program can be found in the manual training schools.

\section{Manual Training Education}

There were numerous schools that did teach high level manufacturing skills while simultaneously teaching the classical curriculum. The Miller School of Albemarle, for example, taught manual training. So, what is manual training and how does it differ from industrial training? Although Charles Vawter and the Miller Manual community were pioneers in forming a manual training institution of learning, they were not alone in such a task. There were other schools that were also designing and implementing such a curriculum. What are the principles of

\footnotetext{
152 James O. Freedman, Liberal Education and the Public Interest (Iowa City: University of Iowa Press, 2003), 56-
} 60. 
such a curriculum, where did it develop, and who else other than Miller Manual implemented it in the United States? These are all important questions.

Manual training is based on the principle that tool practice promotes intellectual growth and to a greater degree builds character. Manual training is a direct outcome and sequence of the kindergarten. The development of kindergarten led to the development of manual training in two ways. Kindergarten exercises showed that hand-work is one of the dominant interests of the child, and these same exercises made clear the critical dependence of brain growth on manual training. Manual training is based on the principle that the idea should never be isolated from the object it represents because joining the idea and the object intensifies the impression on the brain. $^{153}$

Proponents make the case that manual training produces a harmonious development of the whole person, that it makes the student a young adult fully prepared mentally, morally, and physically for the rigors of the adult world. ${ }^{154}$ The proponents go on the state that morality springs from intelligence and civilization depends on having a large percentage of citizens who possess both characteristics. Furthermore, practical intelligence is more conducive to the development of morality than is mere theoretical intelligence. ${ }^{155}$

The noted authority on manual training, Charles Ham, has stated that "Nothing stimulates and quickens the intellect more than the use of mechanical tools. The boy who begins to construct things is compelled at once to begin to think, deliberate, reason, and conclude." He is confronted with natural forces which impede his construction. In order to control these forces, he must first master the laws by which the forces are governed. This develops in the student a

\footnotetext{
${ }^{153}$ Charles H. Ham, Mind and Hand: Manual Training, The Chief Factor in Education (New York: American Book Co., 1900), iii-4.

${ }^{154}$ Ibid., 104.

${ }^{155}$ Ibid., 113-114.
} 
curiosity and a desire to learn. Thus, the training of the eye and the hand reacts upon the brain and stimulates the child's will to learn more about the scientific world. ${ }^{156}$

\section{The Foundations of Manual Training - the English Inventors}

The supporters of manual training point to England in the period 1740-1840 as an example of how the training of the eye and the hand promote higher level thinking. During the aforementioned period, England had no system of public education. The apprentices in her shops were poor, obscure, and, at the start, illiterate. Yet, nearly all of the great British inventions of that age were developed by the apprentices. In their attempts to invent tools and machines, these men had to master the forces of nature. This led many of these apprentices to become highly educated. ${ }^{157}$

For example, Henry Cort, the son of a brick maker, invented the pudding process for refining iron ore, which enabled Britain to use her relatively poor grades of iron ore to become the world's leader in iron manufacturing. Another example is the life and work of Benjamin Huntsman. He was born into a family of poor German immigrant farmers in Lincolnshire. He was apprenticed to a clockmaker, and over the years he moved on to repairing and making handtools. Observant and practical, he began to notice defects in the German steel that was commonly used in the construction of such tools. This led Huntsman to study metallurgy and to conduct experiments in the privacy of his cottage. Over time, Huntsman invented crucible, or cast steel, which was more uniform in composition and freer from impurities than any steel previously produced. His method was the most significant development in steel production up to that time. This led the town of Sheffield to become the cutlery center of world renown. ${ }^{158}$

\footnotetext{
${ }^{156}$ Ibid., 114.

${ }^{157}$ Ibid., 114.

${ }^{158}$ Ibid., 115-116.
} 
Other apprentices from humble backgrounds who helped make Great Britain the manufacturing center of the world were David Mushet, James Neilson, George Stevenson, and James Watt. These men came from the laboring class and were self-educated. Mushet invented the process of using black-band iron stone to greatly reduce the cost of making iron. Black-band iron stone is an abundant form of coal, which was previously believed to be worthless. Neilson invented the hot-blast furnace, which greatly increased the efficiency of smelting iron. ${ }^{159}$

Stevenson rose from the rank of common and illiterate coal-miner to a self-educated mechanical engineer who designed and built the first railroad locomotive. Watt was the son of a carpenter, who was so sickly as a child that he couldn't go outdoors and play with other children. He amused himself by either drawing on the floor with chalk or playing with his father's tools. This manual training led him to become the inventor of the first practical steam engine. ${ }^{160}$

\section{The Role of Women in Manual Training}

These examples of intellectual development in connection with tool-practice are not unusual. The fact that these previously obscure British apprentices became so successful through practices that involved manual training encouraged the early supporters of such an educational discipline. However, such supporters believed that manual training should not be limited to only males. Charles Ham and other manual training proponents make the case that women exert tremendous influence over every child from the cradle to the grave, and that the neglect of people in the past to educate women was a crime. Rousseau argued in Emilius and Sophia that it was unreasonable to expect a child to be properly educated by someone who has not also been properly educated. ${ }^{161}$

\footnotetext{
${ }^{159}$ Ibid., 117-120.

${ }^{160}$ Ibid., $117-120$.

${ }^{161}$ Ibid., 125-129.
} 
Ham argues that mothers should be trained in the principle of education in general and kindergarten in particular. The kindergarten system should then be implemented in all schools and made applicable to all grades and ages of students. Froebel, Pestalozzi, and other early adherents of manual training considered women to be superior in their teaching ability to men. As children receive their first impressions from women, manual training proponents argue that it follows that the education of women is more important, in a sense, than that of men. ${ }^{162}$

\section{Man is an Animal that Uses Tools}

Although Vawter and his counterparts in St. Louis, Chicago, and Massachusetts were developing a new curriculum, the foundations of manual training lie in man's earliest history. The savage was taught to fight, to hunt, and to fish, and in these tasks the brain, the hand, and the eye are trained in unison. He is first given object lessons, in a manner similar to what we do today with children in kindergarten. The bow and arrow are placed in his hands and he fights for his life or he hunts for his dinner. With the growth of civilization, the apprentice system developed and the same reliance on brain, hand, and eye learning was its foundation. Better tools developed and the apprentice was taught how to use them. This led the Scottish historian Thomas Carlyle to write:

Man, is a tool using animal. He can use tools, can devise tools; with these the granite mountains melt into light dust before him; he kneads iron as if it were soft paste; seas are his smooth highway, winds and fire his unwearying steeds. Nowhere do you find him without tools; without tools, he is nothing, with tools he is all! ${ }^{163}$

The introduction of manual training principles in a school setting actually began, however, in the late eighteenth and early nineteenth centuries in the Swiss schools developed by Johann Heinrich Pestalozzi (1746-1827).

\footnotetext{
162 Ibid., 125-129.

163 Ibid., 7.
} 


\section{Pestalozzi’s Role in Manual Training}

In 1770 Pestalozzi and his wife had a son and this marked the beginning of Pestalozzi's interest in education. He began to instruct his son by having the child do things before teaching him in an abstract manner. For example, when the boy was three, Pestalozzi had him plant a vegetable garden so he could see what would happen. This was the beginning of Pestalozzi's approach to "learning by doing."164 Pestalozzi believed in learning through "the head, the hand, and the heart." With his interest in helping the poor and his concern for the dire plight of Swiss orphans, Pestalozzi established for orphans an industrial, moral, and intellectual education. Soon he had twenty children living and working on his farm in what he called the Neuhof Poor School.

His students spent their mornings doing labor such as farm work, spinning, and other textile tasks. Then in the afternoon they were instructed in academic subjects by Pestalozzi and his wife. We shall see that Pestalozzi's division of the day was very similar to what Charles Vawter implemented at the Miller School a century later. Pestalozzi’s students progressed rapidly, leading many more people to apply for admission. But since Pestalozzi’s resources were meager, he successfully appealed to the leading members of his region of Switzerland (the Republic of Bern) for support. The parents of the children, however, ruined the school by encouraging their children to run away after they had been given new clothes, fed, and given enough training that they could, in their parents' opinion, find profitable work. Thus in 1763 Pestalozzi ran out of money and his school closed. ${ }^{165}$

Pestalozzi recorded his methods and the history of Neuhof in a novel entitled Leonard and Gertrude, a Book for the People. It's the story of a school being established that saves a town from degradation. It was widely read and translated into several different languages. It

\footnotetext{
164 Holman, 33-35.

165 Ibid., 41-45.
} 
made Pestalozzi an admired figure. ${ }^{166}$ This development gave Pestalozzi the resources and the community support to create two more labor schools for the poor during his lifetime. His first school was in the Swiss town of Stanz, and it met with great success until it was closed by an invading Napoleonic army. Pestalozzi achieved his greatest success at his last school housed in the Swiss castle at Yverdon. ${ }^{167}$

\section{Manual Training Schools in Russia and the United States}

Then next steps in the development of manual training were taken in Moscow in the midnineteenth century. As the Russians were well behind Western Europe in technical advances, an experimental school was developed whose goal was to produce graduates capable of performing technical work on the same level as found in England and Germany. The Imperial Technical School of Moscow was set up under the leadership of its director, M. Victor Della-Vos. A key feature of the new institution was its educational methodology called the Russian System, which unifies a broad and intensive theoretical preparation with a deep practical education closely connected with industries. ${ }^{168}$ The Russian System was the application of formal discipline to craft instruction. Two ends were striven for - education for industrial efficiency and training for intellectual power. ${ }^{169}$

The Russian System proved so successful that Della-Vos was invited to exhibit at the 1876 Philadelphia Centennial Exposition. Fifty-eight countries staged exhibits. The thesis of the Exposition was "Worldwide Progress under the Benevolent Influence of Science and Technology." The relationship of education to national progress was a key theme of the

\footnotetext{
166 Ibid., 53.

167 Ibid., 113.

168 Ham, 121.

${ }^{169}$ Charles P. Coates, History of the Manual Training School of Washington University, United States Bureau of Education, Bulletin, 1923, No. 3 (Washington: Government Printing Office, 1923), 2.
} 
Centennial. There were hundreds of displays, but the exhibit that attracted the most attention was that presented by Della-Vos. His exhibit made it clear that the Russian educators had scored a breakthrough on the problem of how to organize meaningful shop training as an essential element of technical education. ${ }^{170}$

Before Della-Vos, all previous attempts were based on training in construction shops. These workshops were designed to produce saleable goods. Della-Vos believed that instruction was more important than the school producing saleable goods. He therefore organized instruction shops for each distinctive art - one for joinery, one for blacksmithing, one for carpentry, and so on for the other trades. Della-Vos and his assistants analyzed each trade and its component skills and arranged them in a systematic pedagogical order. Each instruction shop had certain graded exercises that a student had to master before moving to the next station. ${ }^{171}$

\section{Manual Training Develops at MIT}

One of the visitors most impressed by Dell-Vos' exhibit was President John D. Runkle of the Massachusetts Institute of Technology (M.I.T.). Runkle had been struggling with the shop problem at M.I.T. When he saw the Russian Exhibit, he was so impressed that he began to implement the same instructional shop system at M.I.T. Runkle believed that Della-Vos had found the answer to the following question: "Can a system of shop-work instruction be devised of sufficient range and quality which will not consume more time than ought to be spared from the indispensable studies?"172 Runkle then recommended to the M.I.T. Board that they should add this to their course in Mechanical Engineering study through a series of instructional shops

\footnotetext{
${ }^{170}$ Cremin, 23.

${ }^{171}$ Ibid., 23-25.

172 Ham, 333.
} 
or laboratories. The Board agreed with Runkle's recommendation and the Institute began to practice manual training in October of 1878 with the opening of the School of Mechanic Arts. ${ }^{173}$

Runkle designed the curriculum, which was largely based on the example set by DellaVos in Moscow. The Mechanic Arts curriculum consisted of the following:

In Wood:

I. Carpentry and joinery

II. Wood-turning

III. Pattern-making

In Iron:

I. Vise-work

II. Forging

III. Foundry-work

IV. Machine-tool work

This course of study was aimed at students who did not want to become scientific engineers, but rather wanted to pursue industrial pursuits while receiving theoretical and practical instruction in the various arts. The two-year course of study was open to boys fifteen years of age who had completed grammar school. ${ }^{174}$

The theoretical instruction consisted of arithmetic, algebra, geometry, English, physics, and drawing. The practical instruction consisted of laboratory work in the Mechanic Arts listed above. Progressive lessons taught the use of the specific tools and appliances pertaining to each laboratory. In each category, specific items had to be manufactured by the student to a quality standard before the student could progress to the next category. ${ }^{175}$ After the start of the

\footnotetext{
${ }^{173}$ Ibid., 334.

${ }^{174}$ Coates, 59.

175 John D. Runkle, The Manual Element in Education. (Boston: Rand, Avery \& Co., 1882), 18.
} 
Mechanics Arts program, Runkle resigned his position as M.I.T. President and returned to his position as professor of mathematics, a position he held until his death in $1902 .{ }^{176}$

\section{John Dewey and Manual Training}

Sometime after Charles Vawter and other early proponents of manual training education began their work, another scholar who believed that students learn best when they actively construct items was the famous philosopher and educational researcher John Dewey (18591952). Dewey was convinced that children are interested in how the world works - in how people obtain food, clothing, and shelter. To that end, Dewey included cooking and sewing in his school program during the elementary years.

As described earlier in this study, without knowing they were studying mathematics, children did just that by measuring and weighing what they cut and sewed, or cooked. Furthermore, they learned the chemistry of food by tasting fats, carbohydrates, and other ingredients. ${ }^{177}$ Under Dewey, boys as well as girls developed manual skills by learning to work with tools. They made Christmas presents and bookshelves for their homes. Dewey believed that manual training through the eye and hand helped to develop good character as the child took pride in making useful items. ${ }^{178}$

Dewey was convinced that this methodology was the way of the future, which he described in his 1915 book The Schools of To-morrow. Dewey explained how Rousseau believed that children should be taught what they are capable of learning. In other words,

\footnotetext{
${ }^{176}$ Francis E. Wylie, M.I.T. in Perspective: A Pictorial History of the Massachusetts Institute of Technology. (Boston: Little, Brown and Co.:1975), 10-11.

177 John Dewey, The School and Society, Google Books, http://books.google.com/books?id=NBXL2B4OF9gC\&printsec=frontcover\#v=onepage\&q\&f=false (January 11, 2013).

178 Tanner, 36.
} 
education should be based on the native capacities of those who are to be taught. Thus, the study of children was essential in order to learn what these capacities are. ${ }^{179}$

Dewey described the work of early twentieth-century educational researcher Marietta Johnson of Fairhope, Alabama. She ran an experimental elementary program known as The School of Organic Education. Her methods were based on Rousseau's book Emile, which described teaching as a process of natural growth. Dewey described Johnson's approach:

Mrs. Johnson criticizes the conventional school of today. She says it is arranged to make things easy for the teacher who wishes quick and tangible results; that it disregards the full development of the pupils. It is arranged on the fatal plan of a hothouse, forcing to a sterile show, rather than fostering all around growth. The distaste of children for school is a natural and necessary result of such mistakes as these. ${ }^{180}$

Johnson, like Dewey at his Laboratory School, had a school garden where the students learned to plow, rake, and plant. The students then watched their seeds come up, tended to them, and harvested and cooked their produce. In Johnson's school, boys and girls learned carpentry and other forms of handwork. Like Dewey, Johnson believed that these hands-on activities built character. $^{181}$

\section{Manual Training in St. Louis}

Although Runkle applied Della-Vos' methods at M.I.T., it was Calvin M. Woodward of Washington University in St. Louis who is best known for implementing the Russian System in the United States. Educated at Harvard, Woodward joined the faculty of Washington University in 1865. Three years later he was given the task of establishing an engineering department at Washington University. In the course of teaching certain problems in applied mechanics, he gave his students the assignment of preparing illustrative wooden models. To help them make

\footnotetext{
179 John Dewey and Evelyn Dewey, Schools of To-morrow (New York: Knickerbocker Press, 1915$), 1$.

${ }^{180}$ Dewey and Dewey, Schools of To-morrow, 17-18.

${ }^{181}$ Ibid., 32-34.
} 
these wooded models, Woodward brought the University's carpenter into his classroom. Woodward soon realized that nearly all of his students had no experience in handling basic carpentry tools. Woodward decided that before his students could create the mathematical models he had assigned, they had to first become skilled in tool work. ${ }^{182}$

Over the next ten years Woodward became very disenchanted with the quality of his incoming students at Washington University. He became an outspoken critic of the public schools, charging them with teaching "outmoded ideals of gentlemanliness and culture." When Woodward learned of Della-Vos' exhibit at Philadelphia, he became an enthusiastic supporter of the Russian System of manual training education. Committed to a broad and liberal curriculum, Woodward was not willing to make preparation for a specific trade the goal of general schooling. Like Vawter, Woodward believed that students should not specialize at too early an age. Rather, they should study a broad range of classical subjects and then apply them through manual training in the workshop. To accomplish this, Woodward received permission from the Washington University Board to create the Manual Training School of Washington University, which was established on June 6, 1879, eight months after the Miller Manual Labor School had opened in Virginia. ${ }^{183}$

Woodward met with the Chancellor William G. Eliot of Washington University to decide what name to call the new school. They wanted to avoid terms that had negative connotations such as "development school," which was associated with the training of indigent students. When Woodward suggested Manual Training School, Eliot said that no one would know what that meant, to which Woodward replied: "That is what is desired. People will not have

\footnotetext{
182 Cremin, 26.

183 Ibid., 27.
} 
preconceived ideas...." Years later, Woodward elaborated on the meaning of the term manual training:

The name manual training school suggested by me in 1879 still appears to be the best.... The manual training school teaches no trade, prepares for no calling or profession. It gives as wide a training in the practical arts as it does in literary and commercial fields. If people will take the trouble to seek for the meaning of the name, not in the dictionary but in the organization of the school itself, its significance will be easily seen. ${ }^{184}$

In the opening ceremonies, Woodward explained the purpose of the school:

The manual-training school owes its existence to the conviction on the part of the founders that the interests of St. Louis demand for young men a system of education which shall fit them for the actual duties of life in a more direct and positive manner than is done in the ordinary American school.... ${ }^{185}$

Woodward then went on to describe the students' schedule:

The students will divide their working hours as nearly as possible between mental and manual labor... We now come to the manual training proper - to that feature which is to distinguish this school from those around it. How shall we train the hand to keep pace with the eye and the mind, and to fit it well for its future uses? ${ }^{186}$

\section{Criticisms of Manual Training}

When Runkle explained the Russian System of tool instruction at the 1877 National Education Association (NEA), many attendees were impressed but most concluded that the curriculum was suited for “... higher technical institutions like M.I.T.” and not for public or private secondary schools. Other educators viewed manual training less enthusiastically. President Emerson White of Purdue stated that he had "... no expectation that the workshop will ever have an important place in the public school." White argued that the central purpose of

\footnotetext{
${ }^{184}$ Coates, 60-61. It is interesting that Woodward claims or, perhaps, implies that he originated the term "manual training" when in fact it had been used by specific educators for decades and is clearly stated in Samuel Miller's will written years earlier.

185 Ibid., 18.

${ }^{186}$ Ibid., 19.
} 
public schooling was to teach a cultural education common to all Americans, and to teach students the trades would subvert the purpose of public education. ${ }^{187}$

White was soon joined by many other skeptics and the issue of manual training developed into one of the most contentious pedagogical battles of the 1880s. Superintendent Albert P. Marble of the Worcester, Massachusetts public schools was a vocal critic of the "... exaggerated claims and misguided sentimentalism of the manual-training enthusiasts." At the 1882 meeting of the NEA, Marble stated that the secondary schools needed to train boys and girls how to get information from books. He went on to state: "There is no information stored up in the plow, hoe handle, or steam engine, but there is information stored up in books.... The saw is brought into the recitation room, and the teacher says, 'now saw.' It is a thing that does not belong to the school at all. It belongs outside and ought to be attended to outside." 188

Woodward's harshest critic, however, was neither White nor Marble. Instead it was William T. Harris, the former Superintendent of the St. Louis Public Schools. Harris had left his position in St. Louis to take the superintendency of the Concord School of Philosophy in Massachusetts just as Woodward was starting his experiment at Washington University. Harris' first public criticism of Woodward occurred in 1884 when he declared that there was no need to introduce manual training into the public-school program. ${ }^{189}$

Then in 1889 Harris delivered a paper at the NEA Department of Superintendence entitled "The Psychology of Manual Training." Harris argued that educators can be divided into conservatives and progressives. Conservatives stand by the heritage of the past, and progressives criticize the status quo and constantly offer remedies that require change. Harris refers to this as

\footnotetext{
187 Cremin, 28-29.

188 Ibid., 29-30.

${ }^{189}$ Ibid., 30-31.
} 
part of the dialectical process that leads to educational progress. Without the progressive experiments, there will be no advancement. Harris then slyly set a trap for Woodward. He went on to say that even progressives would admit that only one out of one-hundred experiments gain positive results. ${ }^{190}$

Harris did not see manual training as an example of such a positive advancement in education. He viewed the idea of putting the "whole boy" in school as a "... dangerous survival of Rousseauism, one that failed to distinguish between higher and lower faculties in the individual." In regards to tool work being educative, Harris compared such activities to marbles, baseballs, and jackstraws, items Harris declared had no place in the classroom. Harris declared that man's strength lies in his ability to generalize, comprehend, relate, and idealize. The purpose of school is to develop these characteristics, which will enable students to develop into life-long learners. To teach carpentry will give the child a limited knowledge of self, whereas the traditional curriculum offers the child a key to all human wisdom. ${ }^{191}$

These criticisms did not have the effect White, Marble, and Harris desired. Woodward won the debate as more cities established public manual training schools and numerous wealthy businessmen established private manual training schools. In addition to M.I.T. and Washington University, a number of these schools were associated with other famous colleges and universities such as Girard College, Tulane University, Teachers' College, Pratt Institute, Sophie Newcomb College, and Clark University. ${ }^{192}$

\footnotetext{
${ }^{190}$ Ibid., 30-31.

191 Ibid., 31.

${ }^{192}$ Ham, 397-398.
} 


\section{The Decline of Manual Training}

By 1890 thousands of boys and girls were studying machine work, sewing, carpentry, foundry work, and mechanical drawing in thirty-six cities over fifteen states and the District of Columbia. Nevertheless, the victory of Woodward, Ham, Vawter, and other manual training advocates was short-lived. The businessmen who promoted manual training in both public and private schools used the language of Woodward to promote such schooling, but what they wanted was very different from what the manual training educators desired.

The chief concern of the businessmen was practical trade training to give them a labor source other than the growing union regulation of apprenticeships. Furthermore, as tool work moved from wood to metal, especially steel, the machine quickly replaced the hand tool. Artistic handcraft skills then were superseded by productive skill. The end result was a gradual movement in both the St. Louis school and other manual training schools towards less emphasis on the classical curriculum and a clear move towards vocational training. ${ }^{193}$

This trend away from manual training was also influenced by geopolitical concerns. The rising influence of Germany as a major power was based on its position as the dominant industrial state. That strength, in turn, was largely credited to Germany's excellent system of technical schools, the famous Realschule. England copied this type of education and a movement began in the United States to do the same. President Theodore C. Search of the Pennsylvania Museum's School of Industrial Art stated that holding on to classical and literary studies “... was unfair and unjust to the great material interests of the land to leave out of account the obvious demands of industry and commerce." ${ }^{\prime 194}$

\footnotetext{
193 Ibid., 34.

${ }^{194}$ Cremin, 37-38.
} 
One of the first American versions of the Realschule was started in New York City in 1881 by a wealthy architect named Richard T. Auchmuty. Auchmuty had difficulty hiring the number of skilled laborers needed for his many construction projects. This he blamed on the antiquated system of apprenticeship. Craft masters no longer wanted to teach and boys were no longer willing to accept prolonged periods of indenture with little or no wages. So Auchmuty started the New York Trades School that provided courses in bricklaying, plastering, plumbing, carpentry, stonecutting, blacksmithing, tailoring, and printing. ${ }^{195}$

The school made no pretense at providing any type of higher cultural education. The courses were short and intensely practical, and culminated with a rigorous certification exam. J. P. Morgan was so impressed with Auchmuty's school that he donated $\$ 500,000$ to help fund its operations in 1892. ${ }^{196}$ Many other schools soon followed Auchmuty's example. The Pratt Institute in Brooklyn was one such school. It had previously adhered to manual training, but in the 1890s it opened programs in bricklaying, stone carving, and plumbing modeled along the lines of the New York Trades School's program. ${ }^{197}$

By 1910 the movement from manual training to vocational education reached a tipping point. The Association of American Agricultural Colleges' Mitchell Report urging trade instruction in America's schools was accepted by both the American Federation of Labor and the National Association of Manufacturers. Additionally, the National Education Association announced that vocational training was of central importance in training students headed for

\footnotetext{
${ }^{195}$ Ibid., 34-36.

${ }^{196}$ Ibid., 34-36.

${ }^{197}$ Ibid., 37.
} 
careers in industry. By then, twenty-nine states were providing some form of industrial education in their public-school systems. ${ }^{198}$

Despite these trends, the Miller School of Albemarle continued to successfully operate as a manual training school until the 1950s. There are clear reasons why the manual training curriculum established by Vawter had such longevity at the Miller School. First, the classical component of the curriculum was consistently maintained. Thus, students learned higher-order reasoning skills that they carried into their adult lives. These severed them well when they gained positions of authority in the world of business. Secondly, Vawter's "workshop" curriculum anticipated many twentieth-century developments. Students were taught skilled crafts that were just developing in the late nineteenth-century. Miller students were trained as electricians, plumbers, welders, jointers, steam mechanics, and a host of other skilled trades that depended on steam, gas, and electrical power. These were skilled trades that continued to be practiced throughout the twentieth century because they were not rendered obsolete by automation or other technical advances.

${ }^{198}$ Ibid., 48-50. 


\section{Chapter Five}

\section{The Building of Institutions:}

\section{Vawter at Miller Manual and Virginia Tech}

Although he is largely unknown today, during his lifetime Charles Vawter was considered one of Virginia's greatest educators. His work at the Miller Manual Labor School attracted national attention and led several Virginia governors to appoint him to the boards of visitors at three Virginia Colleges. He served as the chair of Virginia Polytechnic Institute's board, and he served in the same capacity at both Virginia State University and at the Farmville State Female Normal School, which is now known as Longwood University. Unfortunately, little is known of his work at Longwood as the April 2001 fire at the university's main administration building destroyed all board minutes from the university's early years. This chapter will explore Vawter's work at both Miller Manual School and Virginia Polytechnic Institute.

In this chapter, I will demonstrate that Vawter was a progressive educator who believed that students of all socio-economic classes deserved a chance to study the classical curriculum while also learning skilled labor tasks. I will also show how Vawter used pedagogy such as Miller's electrical engineering curriculum, something that was revolutionary for that era. I will describe how Vawter, without a template to follow, set up a program at Miller Manual that achieved national recognition for teaching the poor children of Albemarle County both higher order thinking skills and the craft trades. Finally, I will relate how Vawter first saved Virginia Polytechnic Institute from the negative interference of Virginia's politicians and then went on to reorganize the institution and set it on the path to becoming a world famous technical institute. 
After serving as an officer in Virginia's famous Stonewall Brigade during the Civil War, and then as a professor of mathematics at Emory and Henry College for ten years, Charles Vawter was selected by the Albemarle County Court Commissioners of the Estate of Samuel Miller to be the superintendent of the new experimental school that Miller had bequeathed to Albemarle County.

\section{Historical Context - Samuel Miller's Life and Work}

On Saturday March 27, 1869, the Lynchburg Virginian ran a headline story entitled "Samuel Miller the Wealthiest Man in Virginia Dies." Indeed, Miller was not only the wealthiest man in Virginia, he was also one of the wealthiest men in the South. At his death, he left an estate worth over $\$ 2,200,000$. At current values, Miller's estate would be worth in excess of three billion one hundred million dollars.

In the twenty-fifth clause of his will, Miller dedicated the great bulk of his estate to “...the founding, establishment, and perpetual support of a school on the Manual Labor Principle - wherein, at all times, they shall be fed, clothed, and instructed in all branches of a good, plain sound English education, the various languages, both ancient and modern, agriculture, and the useful arts, and wholly free of expense to the pupils, as many poor orphan children and other white children whose parents shall be unable to educate them...."199

This was not a late life decision for Miller for he had been planning such a school for more than thirty years. Miller had already established a similar school for orphaned girls, the Lynchburg Female Orphan Asylum. ${ }^{200}$ He had also made what was then the largest bequest in the history of the University of Virginia - he donated one-hundred thousand dollars to found a

\footnotetext{
199 Anna Barringer, "Pleasant It Is to Remember These Things," Magazine of Albemarle County History 27 (196869), p. 8. See also, B.F.D. Runk, “A Brief History of the Early Years of the Miller Manual Labor School,” Magazine of Albemarle County History 31 (1974), 32.

${ }^{200}$ Rosa F. Yancy, Lynchburg and Its Neighbors (Lynchburg: Warwick House, 1997), 185.
} 
school for practical and experimental agriculture. The University's Miller Hall was named for Samuel Miller and housed the University's Biology Department for most of the twentiethcentury. ${ }^{201}$ His chief aim, however, was to establish a manual labor principle school in Albemarle County.

Why was Miller so dedicated to the founding of such a school for poor children? The answer can be found in Miller's childhood. He grew up as the illegitimate and impoverished son of a single mother. Miller lived in a series of small, dirt-floored cabins with his mother and his brother. Later in life Samuel Miller often spoke about roaming the local briar patches looking for wool left by passing sheep which his mother would weave into clothing to sell. This was used to pay for her sons' education. It was during these school years that the two brothers began to dream of becoming rich and establishing a school for poor Albemarle children where classical academic subjects would be taught along with training in the crafts. ${ }^{202}$

As an adult, Miller became fabulously successful. He traded in hemp, tobacco, and a range of agricultural commodities. He also invested his earnings in state and municipal bonds and bought stock in a number of different banks and railroad companies. ${ }^{203}$

\section{Samuel Miller's Philanthropy}

The executor of Miller's will, Nicholas M. Page (1810-1902), testified after Miller's death that as early as 1837 Miller had told Page that he and his brother John were planning to create a school for poor children in Albemarle as well as an asylum for orphans in Lynchburg. They wanted to do this so other children like them would not have to experience the difficulties

\footnotetext{
${ }^{201}$ Miller Hall was demolished in 2002 to make way for the Special Collections Library. Retrieved November 7 , 2012 from http://www.virginia.edu/insideuva/2002/19/miller_hall.html

202 Bernard Chamberlain, "Samuel Miller, 1792-1869: Albemarle Philanthropist," Magazine of Albemarle County History 28 (1970): 120.

${ }^{203}$ Ibid, 123.
} 
they had gone through during their own childhoods. ${ }^{204}$ The Lynchburg asylum and the University of Virginia’s Miller School of Biology were constructed during Miller's lifetime, while the Miller Manual Labor School of Albemarle was a bequest he carefully spelled out in his will.

A few weeks before his death in 1869 , Samuel Miller executed a unique deed of trust, which has had a profound influence on American higher education. In the deed of trust Miller gave to seven named trustees and their successors certain bonds of the State of Virginia, the Central Virginia Railroad, and the City of Richmond, which had an aggregate value of onehundred thousand dollars. The income from this trust was to be used by the trustees "...to the establishment, maintenance, and support of a school of experimental and practical agriculture to be constituted and established at the University of Virginia by the authorities thereof." Miller stated that vacancies on the board of trustees were to be filled by nominations made by either the trustees or by the circuit court. Miller went so far as to state that if the University of Virginia should cease to exist or become impaired in its ability to function, the trustees could withdraw the fund and incorporate and endow such a school elsewhere. It was this fund that the trustees used at the University of Virginia to create the Miller School of Biology. ${ }^{205}$

This one-hundred-thousand-dollar gift to the University created the first agricultural experiment station established in the United States. In its use of an independent self-perpetuating board of trustees, it has served as the prototype for both the Alumni Board of Trustees of the University of Virginia's Endowment Fund and for similar boards set up at dozens of other universities around the country. It is widely believed that this trust was used by the University of

\footnotetext{
${ }^{204}$ Rare Virginia Pamphlets, Vol. 4. Charles Louis Mosby, The Samuel Miller Will Case (Lynchburg: J.P. Bell, Browne, 1873), vii. Special Collections, Alderman Library, University of Virginia.

${ }^{205}$ Chamberlain, "Samuel Miller, 1792-1869: Albemarle Philanthropist," 124.
} 
Virginia's first president, Edwin A. Alderman, to convince Andrew Carnegie to grant the University a gift to provide for professor's pensions. Carnegie had declined to make such a gift because he had a policy of never making donations to institutions that were under governmental control. Alderman used the Miller Trust example and promised Carnegie that the University would set up a similar group of trustees to hold the professor's pension fund. Alderman then established the Alumni Board of Trustees, which manages all of the University's endowment funds entirely free of governmental control. ${ }^{206}$

After Miller's death, his heirs sued in an attempt to void his will and claim his estate as their inheritance. After nearly a decade of lawsuits to void the twenty-fifth clause of Miller's will, the Virginia Supreme Court declared the clause to be constitutional and construction of the Miller Manual Labor School began in earnest. Manual labor schools were not uncommon in New England in the years following the Civil War. At such institutions, students were given not only a standard academic education but also training in useful arts such as carpentry, foundry work, electrical engineering, textiles, and other industrial trades. ${ }^{207}$ As stated, Miller's correspondence and the memoirs of his closest friends indicate that as early as the 1830s Miller began planning how to create such a secondary school. ${ }^{208}$ Although Miller was extremely generous to a number of different institutions, his greatest act of benevolence was the creation of his manual labor school. Nevertheless, it is unlikely that Samuel Miller's bequest would have been as influential as he had hoped had not Charles E. Vawter played such a key role in Miller's bequest.

\footnotetext{
${ }^{206}$ Ibid., 125.

207 The term electrical engineering, as it was used in the late nineteenth century, is synonymous today to training as an apprentice electrician.

${ }^{208}$ Clara H. Robertson, Keys to the History of Miller School of Albemarle Virginia. Unpublished, Special Collections, Alderman Library, University of Virginia, 385.
} 


\section{The Construction of the School}

Construction of the Miller Manual Labor School finally began in the summer of 1874 after the Virginia General Assembly and the Supreme Court of Virginia validated the twentyfifth clause of Samuel Miller's will in April of that year. On July 1, 1874, Judge John L. Cochran of the Albemarle County Court appointed two University of Virginia professors as the school's first Board of Visitors. ${ }^{209}$ Charles S. Venable, a mathematician, and Francis H. Smith, a natural philosopher, assumed their duties. In early 1876 the Miller Board of Visitors chose architect Albert Lybrock of Richmond to design and Thomas Woodroffe of Richmond to build the school's main building on land located in western Albemarle County previously owned by Samuel Miller. ${ }^{210}$

Less than two years later on August 7, 1878, Main Hall was dedicated. The Main Hall architecture was innovative and reflective of the Progressive Era. This was the period when architecture experienced what is known as the American Renaissance. The goal of this age was to shape culture and society in three ways - aesthetic, social, and professional. All of these aims were in a sense political in that the practitioners of the American Renaissance believed that such architecture would bring order and harmony and help to assimilate all classes of society, including the poor, into a harmonious American culture. ${ }^{211}$ The architect of Main Hall, Albert Lybrock, was a practitioner of this style of construction.

When the construction of the Main Building was completed, a celebration was held for which many important people were invited from Albemarle County, the City of Charlottesville,

\footnotetext{
${ }^{209}$ In the literature of the Miller School of Albemarle the terms "Board of Visitors" and "Board of Trustees" are used interchangeably.

${ }^{210}$ B.F.D. Runk, "A Brief History of the Early Years of the Miller Manual Labor School,” 32.

${ }^{211}$ Annette Benert, The Architectural Imagination of Edith Wharton: Gender, Class, and Power in the Progressive Era (Cranbury, NJ: Fairleigh Dickinson Press, 2007), 38.
} 
other communities in the State of Virginia. The Governor of Virginia, William Holliday, charged those connected with the school to carry out Samuel Miller's wishes to the best of their abilities. A number of other notables were present, including the father of Virginia's publicschool system William H. Ruffner, and Judge J. Randolph Tucker. Tucker then gave a detailed address on the importance of manual labor education in which he made the following points: "No man was ever worth anything who did not work his own way. The great trouble in old Virginia is that we have so few who love work for its own sake - for its glory and its results. Hence the importance of combining manual labor with the instruction of the mind and heart, as designed by Mr. Miller in his school."212

\section{How Vawter Influenced the Program}

The Miller School continued to build for the next several years. In 1880 the Board of Visitors hired A.P. Cutting of Worcester, Massachusetts, M.P. Higgins the superintendent of the Worcester County Free Institute's machine shop, and Thomas Woodroffe to design and build the Miller School's four-story workshop building. It was finished and in use by July 1, 1882.

Woodroffe also directed the construction of the north and south wings to Main Hall. Completed in 1882 and 1884, these wings housed classrooms, study halls, a chapel, the dining hall and kitchen, and dormitory rooms for the students. ${ }^{213}$ Then in August of 1882, on the recommendation of Charles Vawter, the Board selected William H. Seamon to head the Chemistry Department. A recent graduate of the University of Virginia, Seamon was given the

\footnotetext{
${ }^{212}$ Charlottesville Chronicle, August 1878, np. Clipping found in the Miller School of Albemarle Main Office Safe. Miller School of Albemarle Archives. Retrieved June 25, 2014.

${ }^{213}$ Works Progress Administration Writers Program, Jefferson's Albemarle: A guide to Albemarle County and the City of Charlottesville Virginia (Washington, DC: Works Progress Administration, 1941), 132.
} 
task of designing and overseeing the construction of the school's Laboratory Building, which was completed in December of $1885 .^{214}$

Although architects and contractors provided professional services in the construction of these buildings, Vawter was involved in every decision that had to be made both in the planning and implementation processes and, with the Board's approval, Vawter was also responsible for managing the financing for all construction. Vawter was influenced by the progressive educational ideas of the time. Classrooms were modeled after those pioneered by Massachusetts' Quincy School. Every teacher had a separate classroom for the one grade he taught and all students had their own desk. Furthermore, Vawter followed the Prussian model of instruction through a system of gradation based on skill levels rather than the heterogeneous mass of different ages and abilities in the same room which was common to schools of that era. $^{215}$

It was in this work that Vawter's executive skill is clearly evident. The total value of Samuel Miller's estate by report of the court commissioners was $\$ 1,230,150.92$. Out of this the two previously described bequests of one-hundred thousand dollars each were paid to the University of Virginia and to the Lynchburg Orphan Asylum. Additionally, there were the sizable costs paid to legal counsel during the protracted suits to settle the legality of the twentyfifth clause of Miller's will. Therefore, Executor Nicholas Page was able to release for the establishment and support of the school around one million dollars. ${ }^{216}$

\footnotetext{
214 "Papers of the Miller School Alumni Association, Charles Vawters Report of 1892," Special Collections Alderman Library, University of Virginia.

${ }^{215}$ David B. Tyack, The One Best System: A History of American Urban Education (Cambridge: Harvard University Press, 1974), 44-45.

${ }^{216}$ Miller School Catalogue (Miller School, 1901), 48.
} 
By 1901, the value of the Miller School's endowment was $\$ 1,470,968.49$. However, over $\$ 600,000$ had been spent on the buildings, grounds, and equipment for the school's main twelve-hundred-acre campus. Some of these costs are as follows:

- The Main Building: $\$ 140,000$ plus $\$ 60,000$ to equip

- The Machine Shop: $\$ 30,000$ plus $\$ 30,000$ to equip

- The Primary Building: $\$ 10,000$

- The Stables and Silos: $\$ 10,000$

- The Chemical Laboratories: $\$ 25,000$ plus $\$ 4,500$ to equip

Additionally, numerous other structures had been erected for which no records survive. These included the Superintendent's Residence, the school's laundry service, two infirmaries, a hack coach service, a brickyard, and printing, post, and telegraph offices. The stables contained forty horses and fifty cows and the school maintained a large fish pond and a 450,000-gallon reservoir, which was fed by a buried pipe system from the school's five-hundred acre "Orchard Tract" located five miles away to the southwest of Batesville. ${ }^{217}$

\section{Vawter and Edison}

As a progressive educator on the cutting edge of scientific advancement, Vawter believed in using the latest technologies to enhance learning. When Vawter learned of the work that Thomas Edison was undertaking with electricity, Vawter foresaw uses for such at Miller Manual. Thinking that electricity would not only make the campus safer and make the performing of numerous laborious tasks much easier, he also saw a potential for his students' future employment. Progressives believed in learning by doing; if Miller students learned how to work with electricity, they could either find jobs as electricians or perhaps become entrepreneurs and start their own businesses. ${ }^{218}$

\footnotetext{
${ }^{217}$ Ibid., 28.

${ }^{218}$ Uday Shanker, Progressive Education (Ambala City, India: The Indian Publications, 1978), 103.
} 
This led Vawter to purchase two of Thomas Edison's "K" dynamos and 400 of his "A" light bulbs for ten-thousand dollars. The first dynamo and two-hundred bulbs were installed on July 1,1883 , and the second dynamo and the remaining two-hundred bulbs were in operation by March of 1884 . The " $K$ " dynamos were designed to power isolated lighting plants, like that at the Miller Manual School, as opposed to Edison's larger dynamos which were installed in urban power stations. The "K" dynamo was a thirty-five-horsepower machine that produced twohundred and twenty volts and one-hundred and eighty-three amps. The "A" bulbs were rated at sixteen candlepower, which is roughly the equivalent illumination produced by sixteen high quality candles made from spermaceti found in the heads of sperm whales. ${ }^{219}$ The Miller Manual Labor School was not the first institution in the South to electrify but it was among the first. ${ }^{220} \mathrm{~A}$ mill in Augusta, Georgia had installed two "K" dynamos and several hundred of Edison's bulbs a year before Vawter's purchase. ${ }^{221}$

On October 29, 1879, Edison discovered the carbonized cotton filament and successfully tested his first incandescent light bulb. ${ }^{222}$ Vawter became one of Edison's first customers for these light bulbs. Four hundred pounds of coal were needed to produce the steam needed to power the Miller dynamos for six hours. Not satisfied with such a method, and always current in his knowledge of technological development, Vawter had the school switch to a hydroelectric system that used water from the school's reservoir. ${ }^{223}$

This system required a skilled operator to adjust the flow of direct current to match the demand for power as machines in the school's plant were switched on and off. At night, the

\footnotetext{
${ }^{219}$ Paul Israel and Thomas E. Jeffrey, eds., The Papers of Thomas Edison Vol.6: Electrifying New York and Abroad, April 1881-March 1883 (Baltimore: Johns Hopkins Press, 2007), 838.

${ }^{220}$ Miller School Catalogue (Miller School, 1885), 2.

${ }^{221}$ Edison Electric Light Co., Bulletin No. 21(New York: Edison, 1883), 54.

${ }^{222}$ Francis A. Jones, Thomas Alva Edison: Sixty Years of an Inventor's Life (New York: Thomas Y. Crowell \& Co., 1907), 115.

223 "Minutes of the Board of Visitors," Miller Manual School No. 1(Miller School), 51.
} 
lights were extinguished and the dynamos switched off by 10:00 p.m. A student operator, remembered that he would shut off one generator, which would cause the lights to dim to half power. This would warn the school community that he was about to shut down the system. Fifteen minutes later, the operator would shut down the second generator and the school would have no electric power until the next day. These lights made matches, oil lamps, candles, and other items prone to the accidental fires largely unnecessary and this made for a safer campus. ${ }^{224}$ Several generations of students became skilled electricians through their work at Miller Manual. One such student was Irvin Baber of Crozet, Virginia. Baber entered Miller as a fifteen-year-old in 1932 and spent the next four years at the school. During that time, he operated the Power House from 6:00 p.m. until lights out at 10:00 p.m. When interviewed regarding his work at Miller, Baber stated the following: "It changed my way of thinking; I developed a way to think mechanically and see how machines work. Everything I learned helped me - I could see how each part of a machine related to the entire machine system, and I could assess how to make the machine better." 225 Baber was the type of child Charles Vawter loved to help. He was a poor boy from Batesville whose father died when he was twelve and whose mother convinced the Albemarle County Court to enroll him at Miller Manual. The school changed his life. ${ }^{226}$

Vawter's realization that electricity was destined to be a major factor in the economy of the future differentiates him not only from progressive educators like Armstrong and Washington who favored industrial training but also from other progressives who favored manual training education. Calvin Woodward of the Manual Training School of Washington University in St.

\footnotetext{
${ }^{224}$ Ibid, 51.

${ }^{225}$ Irvin Baber, interview by Hugh A. Meagher, June 24, 2014, interview transcript Miller School of Albemarle Archives, Charlottesville, VA.

${ }^{226}$ Baber interview.
} 
Louis and John D. Runkle at the Massachusetts Institute of Technology created curricula very similar to Vawter's but without the element of electricity. ${ }^{227}$

\section{The Establishment of Crozet and Western Albemarle's Infrastructure}

The Power House exemplifies the fact that Vawter did not limit construction to the central campus. The board, at Vawter's suggestion, made a number of land purchases to add to its contiguous holdings. Miller Manual then constructed a series of roads to interconnect these holdings. The first macadamized hard-top road constructed in Albemarle County was built by the school to connect the main campus with a new railroad depot the school constructed five and one-half miles to the north. Around this depot grew a village that was given the name of Crozet. This was where Vawter established the Miller School Post Office, Express Office, and Telegraph Office. ${ }^{228}$ Coal and other supplies ordered by the school arrived by train in Crozet, and were hauled by horse or mule team over the macadamized road. There were plans to build a narrowgauge railroad between the Crozet Depot and the school's campus but the hard surface road made such construction unnecessary. ${ }^{229}$

Each item spent by the Miller School was first proposed to Vawter, and if approved, the good or service was purchased and the bill was submitted to Vawter and then recorded. ${ }^{230}$ These expenses and the school's endowment had continued to grow because of Vawter's shrewd investing in Virginia Perpetual Education Certificates securities, which paid an annual income of over seventy-eight thousand dollars. These bonds were Virginia State Bonds which paid an interest rate of six percent. ${ }^{231}$

${ }^{227}$ Coates, 27-28.

${ }^{228}$ Miller School Catalogue (Miller School, 1885), 2.

${ }^{229}$ Runk, 47.

${ }^{230}$ Many of these receipts and Vawter's comments can be found in the Victorian safe found in the Miller School of Albemarle's Main Office.

${ }^{231}$ Runk, 48. 


\section{The Miller Manual Labor School Curriculum}

Lawrence Cremin described Progressive Education as a by-product of the broader Progressive Movement. Progressive Education was a protest against traditional schooling with its rigid social barriers. At its core, Progressive Education was an attempt to realize the promise of American life that all men are created equal and that one's status should depend on merit. ${ }^{232}$

The Miller Manual School was an attempt to forge this progressive ideal that would enable the poor children of Albemarle to realize the "promise of American life," or what today is known as the American Dream. The Miller School was not alone in viewing manual training as a means to such a goal but it was the pioneer of manual training education in the South. Progressive educational ideas were put into practice in a number of different settings. Some were implemented in public systems, such as the reforms undertaken by Francis W. Parker in Quincy, Massachusetts. Other pedagogical experiments were privately funded, such as Dewey's Laboratory School in Chicago. ${ }^{233}$ This was also the case with the Vawter's work at Miller Manual.

The first session of the Miller Manual School in 1878-79 was one of experimentation. Vawter was charged with the task of designing and operating a curriculum which had never been implemented at the secondary school level in the South and which had just recently been implemented only in two schools in the North and one in the Midwest. In the Northeast, only the Massachusetts Institute in Boston, which was later renamed the Massachusetts Institute of Technology (MIT), and the Worcester Polytechnic Institute, which was then called the Worcester County Free Institute, were in the field of industrial education, and they were both in their early

\footnotetext{
232 Cremin, 88.

${ }^{233}$ Ibid., 56.
} 
years of development. Then in 1879, one year after the opening of the Miller Manual School, the Manual Training School of Washington University opened in St. Louis. ${ }^{234}$

MIT was just beginning its experiment in manual training. However, MIT's

administrators were so fearful that students might develop a squalid desire to make money that they prohibited the completion of any student made industrial good for fear that it might have value. The Worcester County Free Institute started its work at the other extreme. The Worcester superintendent, M. P. Higgins, believed that everything his students made should have value and be prepared for sale. Both of these institutions taught the value of skilled manual labor. This was not a difficult task because the culture of the North placed a high value on labor. This was not the case in the South. Vawter faced great prejudice -- to dignify labor in the South was difficult. The Negro viewed labor as slave work and the white man regarded manual labor as the domain of the Negro, and therefore beneath him. ${ }^{235}$ In a 1900 speech Vawter recalled the challenge he faced:

To educate away from this false idea on the part of the whites and make all kinds of labor honorable was the difficult task before us....For it became necessary to teach our own race that a man is more honorable who earns a living for himself and those dependent upon him by honest labor, than he who by the tricks of trade accumulates to himself what others have made, and that he who makes a single horse-shoe nail adds more to the material wealth of a country than he who by doubtful means transfer a railroad from one man's pocket to another man's pocket. ${ }^{236}$

This was a real challenge in the Ragged Mountains of Albemarle County. The locals were steadfast in their ways and viewed the entire Miller School project as "Vawter's Folly." In the same 1900 speech, Vawter explained that he did several things to change this mindset,

\footnotetext{
234 Coates, 18.

${ }^{235}$ Miller School Catalogue (Miller School, 1901), 49-50.

${ }^{236}$ Charles E. Vawter, "The Promotion and Encouragement of Manufactures, the Mechanic and Useful Arts," Speech delivered before the Virginia Mechanic's Institute, Richmond, VA, May 1889. Miller School of Albemarle Archives, 13.
} 
"Therefore in order to dignify labor the most beautiful building upon the Miller School grounds, which are the most magnificent to be found in the South, was a work shop and was called the Workshop."

Vawter believed that both MIT and Worchester based their manual training at extremes. Vawter believed in a middle path - somewhere between making nothing of value and only making objects of value. He believed that the elementary and secondary years were a time of broad experimentation -- if a student made something of value, that was not as important as the learning process. In this sense, Vawter was following the same path as William James, Oliver Wendell Holmes, John Dewey, and other pragmatic members of the Metaphysical Club who believed in first thinking about a problem, then actually constructing the item in question, and then following up by determining what actually "works." These educators understood that knowledge is inseparable from doing. ${ }^{237}$

Furthermore, Vawter believed the student should be exposed to a wide range of manual training so that aptitude and interest could be assessed. In a speech delivered to the Virginia Mechanic's Institute in 1889, Vawter stated: "It is not desirable for a boy too early to learn a trade. Learning a trade circumscribes, confines, dwarfs." 238 Vawter believed that learning should begin at what he called the "bottom" - in the elementary classes. Instead of beginning in the machine shops, the manual training curriculum began in the elementary classrooms of the Miller Manual School. ${ }^{239}$

\footnotetext{
${ }^{237}$ Menand, 322.

${ }^{238}$ Charles E. Vawter, "The Promotion and Encouragement of Manufactures, the Mechanic and Useful Arts," Speech delivered before the Virginia Mechanic's Institute, Richmond, VA, May 1889. Miller School of Albemarle Archives, 13.

${ }^{239}$ Miller Memories (Miller School, 1927), 21.
} 
Like Horace Mann and John Dewey, Vawter viewed the interests of the school as being the same as the greater interests of the larger society. The aim of education was to fit children not only for society but also to enable them to have a rich personal life. ${ }^{240}$ Towards this end, Vawter aimed to create a school that would combine classical and manual training in the primary, intermediate, and secondary levels. With no template for him to copy, it is a testament to his skill as an educator that he was able to rapidly create and set into motion the school's departments.

\section{Vawter's Work at Virginia's Public Colleges}

From 1886 until his death in 1905, Charles Vawter did a great deal to strengthen both Virginia Polytechnic Institute and Virginia State University in his work as rector of the board of visitors at both institutions. In both Blacksburg and Petersburg, he consistently worked to develop and implement programs that were progressive in nature. Like William James, Vawter emphasized the practical over the abstract. He was a believer in learning by doing, group work, and a curriculum centered on problem solving and the development of critical thinking skills.

Vawter believed that education should teach the type of social responsibility necessary for the survival of the American democracy. At every school with which he was associated, Vawter opposed strict versions of the classical curriculum because it emphasized memorization, the exclusion of technical studies, and a preference for the upper social classes. He certainly believed in the worthiness of every child, but he was a product of his place and time.

Vawter was constrained by the world around him. At neither Virginia Polytechnic nor Virginia State, did Vawter push for the inclusion of women into the student body. This is curious because at Miller Manual Vawter developed a type of coeducational program that was

${ }^{240}$ Curti, 132. 
very similar to what was practiced at coordinate colleges like Sophie Newcomb, Tufts, and Western Reserve. However, even among progressives, there was a strain of chauvinism. It was one thing for girls to be afforded a secondary education and an altogether different issue for young ladies to be included in higher education. In a similar fashion, Vawter expressed no thoughts regarding the racial segregation of education. In Virginia during Vawter's lifetime, white supremacy was assumed part of the natural order, thus both Virginia State and Virginia Tech were segregated, male institutions.

\section{The Morrill Act and the Establishment of Virginia Tech}

Virginia Tech, originally known as Virginia Agricultural and Mechanical College (Virginia A\&M), was founded in 1872 as a result of the Morrill Land Grant College Act of 1862. Even though this was before what today is known as the Progressive Era, the intellectual forces behind the Land Grant College Movement were progressive in nature. The idea that there is a place in higher education for the branches of learning related to agriculture and the mechanic arts was revolutionary. The background for this act involved several factors. America was rapidly industrializing and there was a need to train sufficient numbers of workers for the new demands industry required. The expanding population required agricultural production to increase as well. The Morrill Act, like Progressive Education thirty years later, was based on the concept that a "public interest" or "common good" exists. The goal of the Land Grant College Act was to aid the lower and middle classes through education, specifically public education. ${ }^{241}$ This same belief is at the heart of progressivism.

Charles Vawter played a key role at Virginia A\&M in implementing the progressive educational practices of the Morrill Act. He was a member of the Board of Visitors from

\footnotetext{
${ }^{241}$ Nugent, 2-3.
} 
January 1886 until he resigned for reasons of health in 1899. During much of his tenure he served as the board rector. At the time of Vawter's appointment, Virginia A\&M was threatened by a number of developments and there was a serious movement in the Virginia legislature to close the school. Furthermore, the school was used as a patronage plum by the rival Virginia political parties. This resulted in frequent changes of board members, administration, faculty, and program, all of which were damaging to the school's development. Vawter played a key role in the work that overcame these problems and put Virginia A\&M on the solid footing that enabled the school to grow into the world class institution it is today.

The Morrill Act provided that each state would receive 30,000 acres of public land without mineral rights for each senator and representative in Congress according to the representation determined by the 1860 census. The individual states then would be required to sell the land, for which they would receive land script money, and then the state would be required to spend the script according to the stipulations of the Act. ${ }^{242}$ With the end of the Civil War in 1865, the Virginia General Assembly took up the issue of how to use the Land Grant monies to establish a technical and agricultural system of education. The money for such a program was eyed acquisitively by numerous existing Virginia schools. The fact that the Land Grant monies were not awarded to one of these existing colleges was because of the influence of one of Virginia's educational pioneers, William H. Ruffner of Lexington. ${ }^{243}$

\section{William Ruffner's Role in the Establishment of Virginia Tech}

Ruffner was Virginia's first Superintendent of Public Education and was an early pioneer of Progressive Education. He was also an early adherent to a practical system of agricultural

\footnotetext{
242 John P. Cochran, "The Virginia Agricultural and Mechanical College: The Formative Half Century, 1872-1919, of Virginia Polytechnic Institute." (Unpublished Ph. D. dissertation, University of Alabama, 1961), 6-7.

243 Peter Wallenstein, Virginia Tech: Land Grant University, 1872-1997 (Blacksburg: Pocahontas Press, 1997), 42.
} 
education. As early as 1866 he appeared before the General Assembly and stated that the Morrill Act Land Grant funds should not be given to a college already in existence, but rather should be used to finance the creation of a new college devoted specifically to agricultural education. He believed that if agricultural education was added to the curriculum of an existing college, it would be emasculated by the liberal arts programs already in existence. ${ }^{244}$

Ruffner believed, like Charles Vawter, that the right kind of education would help dispel the prevailing prejudice held by the white public towards manual labor. Such education would also bring about a dramatic increase in productive industry and this would offset the cost to the state for providing such technical education. Ruffner's position was seconded by the Virginia Agricultural Society at its annual meeting in December of $1871 .{ }^{245}$ Thus Ruffner played a prominent role in the Virginia General Assembly's choosing land donated by the Methodist Synod in Blacksburg as the site for the new Virginia Agricultural and Mechanical College. ${ }^{246}$

Ruffner was a strong proponent of Virginia A\&M developing a curriculum suited for the instruction of agricultural and the polytechnic studies. He believed that the University of Virginia should devote itself to teaching the highest level of literary and theoretical studies with little or any concern for the utilitarian or practical. On the other hand, the technical college should emphasize the practical application of its program and should be flexible and change to meet the practical needs of the public.

Ruffner also recognized the difficulty of establishing a proper balance between practical training and general scientific instruction, upon which the practical training was dependent. ${ }^{247}$

\footnotetext{
${ }^{244}$ Duncan L. Kinnear, The First 100 Years; A History of Virginia Polytechnic Institute and State University (Blacksburg: Virginia Polytechnic Institute Educational Foundation, Inc., 1972), 24.

245 Cochran, 21-22.

${ }^{246}$ Kinnear, 53. The land in Blacksburg had previously been a small Methodist college named the Preston and Olin Institute. The school was later renamed Virginia Polytechnic Institute and was often referred to as VPI.

${ }^{247}$ Ibid., 52-54.
} 
This was to be accomplished through a three-year program consisting of study in classical academic subjects in addition to technical courses in agriculture and the mechanics. ${ }^{248}$

Despite Ruffner's grand plans, very little in the manner of Progressive Education occurred at Virginia A\&M from its founding in 1872 to the appointment of Charles Vawter to the board of visitors in 1886 . This period was marked by constant struggles between rival Virginia political parties that nearly destroyed the Blacksburg institution. The DemocraticConservative Party had controlled Virginia when the institution was organized and the party dominated Virginia for the next several years. However, in 1877 the Readjuster Party won control of the legislature. The party then maintained control of the legislature in the elections of 1879 and 1881, as well as electing their candidate governor in 1881. The problem of Virginia's state debt was the key factor in the rise of the Readjustor Party. ${ }^{249}$ In general the party campaigned on a platform of social reform that proved enormously popular with the "plain people" of the state. ${ }^{250}$

\section{Vawter's Work at Virginia Tech}

The conflict between the Democrats and the Readjustors was finally resolved in the fall of 1885; the Democrats increased their majorities in both houses of the General Assembly and their candidate Fitzhugh Lee was elected governor. This election marked the end of the Readjuster Party as most of the party's members then moved to either the Democratic or Republican Parties where they remained. Fitzhugh Lee was sworn into office on January 1, 1886 and immediately named four Democrats to fill the Virginia A\&M Board of Visitor positions

\footnotetext{
${ }^{248}$ Ibid, 58.

249 Wallenstein, 55.

${ }^{250}$ Kinnear, 99-100.
} 
which had become vacant on that day. One of the Democrats Lee nominated was Charles E. Vawter. $^{251}$

The new board which met on January 23, 1886 named Vawter and J. D. H. Ross as a twoman committee to prepare and present to the board at its next meeting a plan of organization and operation for the college. At the March $23^{\text {rd }}$ meeting Vawter and Ross presented their plan. As pragmatic progressives, they stated that the college should provide its students with a "broad, liberal, practical, industrial education in the line of agriculture and the mechanic arts." The board supported this goal and then went on record by stating that to achieve this goal it would be necessary for the board to be "...untrammeled and free to select the very best men available...." for the faculty and staff. Towards that end the board then announced that all faculty and staff would be removed as of the date of July first. They then announced that the new president would work jointly with the board to determine the offices to fill and the salary scale to be followed. ${ }^{252}$

This was the first time that the president of Virginia A\&M was publicly permitted to advise any of the various Boards of Visitors concerning the organization of the college and the selection of the faculty. Vawter also proposed a policy the board adopted that was designed to remove the malignant effects of politics. In keeping with the progressive belief in fair and open operations, the board resolved that all officers of the college not be permitted to engage in partisan politics beyond simply casting their vote for the candidate of their choice. They also resolved that all official communications from the faculty to the board must come through the college's president. The board then selected General Lunsford Lindsay Lomax as president.

${ }^{251}$ Ibid., 118-119.
${ }^{252}$ Ibid., 118-119. 
Lomax had no previous experience as an educational administrator, but he was a close friend of Fitzhugh Lee's as they had been classmates at West Point in the early 1850 s. ${ }^{253}$

\section{Vawter's Role in Strengthening the Academic Program at Virginia Tech}

By the mid-1880s Virginia's culture was changing as more citizens began to turn away from the sorrows of the Civil War and look towards the future. In addition, the political strife that had done so much damage to the Blacksburg school began to cool rapidly. In April of 1885, at the State Farmers' Convention in Richmond, Charles Vawter introduced a resolution asking the legislature to establish a department of technology as well as an agricultural experiment station at one of the existing state institutions. This proposal was received enthusiastically by the Farmers' Convention and led to a debate over where the school of technology should be located. ${ }^{254}$

The debate almost turned into a repeat of the sectional rivalries that occurred when the legislature considered how to use the Morrill funds. But to end the debate, the convention adopted a resolution to appoint a committee to determine where the school of technology should be located, and Charles Vawter was made the chairman of this committee. As there was federal money available for the agricultural station, Vawter's committee proposed that it be located at Blacksburg. This proposal was accepted by the legislature and passed in March of 1886. In the excitement over the passage of the agricultural station, the issue of where to locate the school of technology was temporarily placed on hold. ${ }^{255}$

Meanwhile, Vawter had been appointed to the Virginia A\&M Board of Visitors, and he and the rest of the board began work on the reorganization of the college. Vawter forcefully

\footnotetext{
${ }^{253}$ Kinnear, 119-122. See also Wallenstein, 66.

${ }^{254}$ Ibid., 122-123.

${ }^{255}$ Ibid., 123-125.
} 
advocated that the school's preparatory department be dropped. Vawter believed that too many students took the preparatory classes in order to avoid the military training and the more rigorous academic courses in mathematics, languages, English, and science. Vawter argued that these courses negatively impacted the academic climate found on the campus and damaged the reputation of the college throughout the state..$^{256}$

Vawter believed the preparatory students remained as illiterate upon leaving college as they were when they entered. In Vawter's opinion, it was absolutely inexcusable for the college to produce illiterate alumni. The board then changed the degree that preparatory graduates received to one of lower status, a B.Sc. degree. We can see that Vawter's determination to require a broad and rigorous liberal arts education at the Virginia Agricultural and Mechanical College was very different from what he was mandated by the Virginia governor and state senate to put into place at the Virginia Normal and Collegiate Institute in Petersburg. ${ }^{257}$

Vawter brought to the board something that had been largely absent in the past, experience in educational administration, including the design and implementation of a program of Progressive Education. He was an articulate and experienced leader whom people were quick to follow. As the superintendent of Miller Manual, he managed an endowment and annual income far greater than that of the Virginia Agricultural and Mechanical College, thus he was helpful in bringing the college's finances into order.

\section{Vawter's Views of the Virginia System of Education}

Vawter's greatest contribution, however, was not his pragmatism and practical experience but his deep-seated conviction that Virginia needed to develop a program that was

\footnotetext{
${ }^{256}$ Ibid., 125.

${ }^{257}$ Ibid., 125. Also, see Board of Visitors Minutes for the Virginia Normal and Collegiate Institute. April 14, 1902 , p.30. See Chapter Three of this study.
} 
aligned to the needs and conditions of Virginia and the South in the post war era. He was also in a position to devote the time and the effort to bring such a system into existence. Once on the Board of Visitors, Vawter immediately began a concerted effort to identify the mission and the place that Virginia A\&M should hold and perform in the Virginia educational system. ${ }^{258}$

The Virginia Polytechnic Institute historian Duncan Kinnear describes Vawter's work in Blacksburg in the following manner: "It is quite significant that the frame of reference within which he worked during his entire tenure on the board was dominated more by his concept of the needs existing in a statewide system of education for Virginia than it was by any interpretation of the requirements and implementation of the Morrill Act." 259

A good example of Kinnear's point can be seen in Vawter's reaction to the University of Virginia's debate regarding the future of their engineering program. As a leader in the field of technical education, Vawter was frequently asked advice on the topic. One occasion was in July of 1887 when Dr. W. C. N. Randolph, the Rector of the University of Virginia's Board of Visitors, asked Vawter if the university would be wise to abolish the Department of Engineering. Vawter's reply to Randolph was tart:

If there be barriers of prejudice [against engineering in the South], she [the University of Virginia] should lead the way against them. You cannot in all the wide fields of education expend money where the results to our people will be more surely felt for good. To abolish this department at the University of Virginia would, therefore, be a fatal mistake. $^{260}$

Vawter was first and foremost a Virginian who was dedicated to fostering pragmatic and progressive educational practices that would strengthen the

\footnotetext{
${ }^{258}$ Ibid., 129.

${ }^{259}$ Ibid., 130.

${ }^{260}$ Charles Vawter, “Correspondence with regard to the Civil and Mechanical Department at the University of Virginia,' Miller School of Albemarle Archives, 4.
} 
commonwealth. As there existed a distinct prejudice in traditional universities against disciplines outside of the classical curriculum, there was a strong possibility that the University of Virginia would have abolished its engineering program had it not been for Vawter's intervention.

\section{Vawter as Rector of the Virginia Tech Board of Visitors}

Vawter's work was of such high caliber that he became the first board member to be reappointed to a second consecutive term when Governor McKinney did so in 1890. Vawter was then elected Rector of the Board of Visitors, and he immediately turned his focus on the dissatisfaction that the state's rural interests were directing at the college. Most of the state's Farmer's Alliance was very dissatisfied with the newly formed Agricultural Experiment Station. They were impatient and critical that the station had not accomplished immediate results and produced transformative applications for the state's farming interests. The Alliance's periodical, The Southern Planter, editorialized that the station was spending its time and budget “...illustrating and working the fads of the professors instead of dealing with the practical problems of everyday farmers." Vawter urged the board to be cautious and not respond to the Alliance's criticisms by immediately replacing the president and numerous faculty members. He proposed that the visitors make a thorough study of the college and the mission that the school should be fulfilling for the state. ${ }^{261}$

The study was made and evidence indicates that all members of the board became fully familiar with both the elements of a technical education and with the current dissatisfaction with the college's instruction in agriculture. The study also gathered information regarding the progress made at other land grant colleges. The board reached consensus that the best program

\footnotetext{
${ }^{261}$ Kinnear, 132.
} 
for Virginia A\&M would be to reorganize the college on a two-track system of mechanics and agriculture. Furthermore, the funding necessary for this reorganization was available with the federal government's passage of the Hatch Act and the Second Morrill Act. Such a reorganization, the board reported, would make Virginia A\&M “...a true agricultural and mechanical school that Virginia would be proud of." The proposal was then submitted to the faculty so the board could gather the "...views of the professors on the subject."

This led to a crisis which Vawter skillfully managed. To the board's surprise, a number of faculty members were strongly opposed to the proposal, as was President Lomax. In particular, Lomax was opposed to restricting the college's offerings to only mechanics and agriculture. Lomax stated that he viewed Virginia A\&M as “...a stepping stone from the free school. If we had money enough for professors in any branch that a poor boy wanted to study, I thought it was our duty to give it to them." Vawter and the rest of the board believed that the state had numerous institutions where literary pursuits could be followed. These included the University of Virginia, thus making such a program in Blacksburg unnecessary and wasteful. ${ }^{263}$

As the board continued to discuss their options a consensus developed that Virginia A\&M should be a technical school in which all of the sciences related to mechanics and agriculture would be emphasized. Although the board minutes of the era were destroyed in the administrative building fire of February 1900, surviving letters show that Vawter was the leader in moving the board to this position. He drew on his experience in setting up and administering

\footnotetext{
262 Kinnear, 132-133. See also Wallenstein, 72, and Cochran 156. The Hatch Act of 1887 gave federal funds to state land-grant colleges in order to create a series of agricultural experiment stations. The bill was named for Congressman William Hatch who chaired the House Agriculture Committee at the time the bill was introduced. Retrieved August 2, 2014 from http://www.lsuagcenter.com/en/communications/publications/agmag/Archive/2012/Spring/History-of-the-HatchAct-of-1887.htm ${ }^{263}$ Kinnear, 133.
} 
the curriculum at Miller Manual and was able to convince the other board members that their proposed plan would not restrict the college's offerings.

He argued that the plan would expand the areas of curriculum that were already in place. He was successful in convincing the board that the plan would aid both the classroom instruction of agriculture and the Agricultural Experiment Station. Nevertheless, Lomax and several faculty members continued to resist the changes. Although Lomax enjoyed a friendly relationship with all of the board members, his resistance had an effect. Several members began to believe that Lomax did not have the skills needed to lead the school in this new direction. At this point, egregious acts of student misbehavior forced the board's hand. ${ }^{264}$

Lomax had been rather passive in the last years of his tenure regarding a type of hazing the older students inflicted on younger students. This was a time when the traditional college culture was being impacted by the changing mores of the Progressive Era. Excessive drinking and humiliating hazing were being replaced by activities that benefitted the entire university community, such as the development of honor societies, philanthropic work, and dramatic and musical competitions. Lynn Gordon in Gender and Higher Education in the Progressive Era describes how, traditionally, men were initiated violently into college culture as freshmen. ${ }^{265}$

This was certainly true at Virginia A\&M where the practice of "bucking" was commonplace. This consisted of two older students firmly holding another student and striking him against a post or wall, or holding the student up while others paddled him with bayonet scabbards or other objects. In the fall of 1890 one student insisted that he had been bucked more

\footnotetext{
${ }^{264}$ Ibid., 133.

265 Gordon, 53.
} 
than one hundred times in the previous year and that after each incident he was so sore that he could hardly walk. ${ }^{266}$

When this news became public, rumors circulated depicting the students as a bunch of derelict rowdies with low morals. This assessment was confirmed in the minds of many state citizens by another incident which occurred in the days before Christmas Break in December of 1890. A number of students held a party in Number One Barracks. Unfortunately, to help them get in the proper Christmas spirit they imbibed copious amounts of a local moonshine known as "Brush Mountain Spirits." By the end of the evening they had broken doors and windows, torn off numerous door and window casements, broken up tables and chairs, and hurled the broken furniture out of the smashed upstairs windows. These acts convinced the board that it was time to make changes at the college. ${ }^{267}$

When the board met in Richmond on January 15, 1891, several members were so angry that they wanted to fire the entire faculty. Vawter forcefully objected to such a rash move. Pragmatically, he counseled that the board needed "... to clarify its own thinking as to the function of the school and then to determine which members of the faculty, if any, should be removed." The board agreed and determined that at their next meeting on April 7, 1891, they would make the changes that were needed. In the report of their January meeting, led by their rector Vawter, the board stated:

The board was convinced that the school was, in many particulars, not accomplishing for Virginia what it should do. That in no true sense of the word could it be called an "agricultural college," that as an agrarian institution, both as regards the station and the college, the State of Virginia would be but little poorer, or scarcely feel the loss, were its existence blotted out; that its leading object, as the law directs, was not being accomplished; that there were evils that should be corrected; and that there were habits and customs there that should be changed. ${ }^{268}$

\footnotetext{
${ }^{266}$ Kinnear, 134.

${ }^{267}$ Kinnear, 129, 133-134. See also Cochran, 156.

${ }^{268}$ Ibid., 134.
} 
The board decided that the prime object of the college was not to furnish a cheap and low-grade collegiate education; its object was higher, and the board stipulated that if the college did not transform itself into a first-rate intuition there was no place for it in the educational system of Virginia. The board knew that Virginia sadly needed and was loudly calling for true technical education. Such was the demand for it that Virginia's young men were going north to get what the board believed Virginia should give them at home. ${ }^{269}$

Led by Vawter, the board reported "We do not wish to dwarf the study of our mother tongue, of the modern languages, or of the sciences. But we do intend to make the college what it should be - a true agricultural and mechanical school that Virginia can be proud of." At the April meeting the board voted to remove Lomax. Vawter and the board then appointed an interim president and released several professors whom they believed did not have the training and qualifications necessary for the new program the board was about to implement at the college. ${ }^{270}$

\section{The Selection of President John McBryde}

They then began an immediate search for a new president. Vawter took the lead in this work. Ever practical, he wrote college presidents all over the South asking for names whom they believed would be suitable candidates. The President of the University of Tennessee, a native Virginian by the name of Charles W. Dabney, wrote Vawter and strongly recommended John M. McBryde, the President of the University of South Carolina. ${ }^{271}$

Dabney spelled out several qualities that he believed Vawter should consider. Born in South Carolina on May 7, 1841, McBryde graduated from the University of Virginia and served

\footnotetext{
${ }^{269}$ Ibid., 134.

270 Ibid, 134.

${ }^{271}$ Ibid., 135.
} 
in both the Confederate Army and government in Richmond. McBryde then spent several years as a practical farmer in Albemarle County, Virginia. During his time in Albemarle, McBryde served as a trustee for the Miller Fund, which was used to establish the University of Virginia's School of Agriculture and the nation's first agricultural research station. This fund was a $\$ 100,000$ bequest made by Samuel Miller before he died. Miller stipulated that the bequest be used for the aforementioned purposes. ${ }^{272}$

Additionally, Dabney stated that McBryde had “...done as much fine work in scientific agriculture as any man has done in the last five years .... I believe he [McBryde] would make your agricultural and mechanical college a success at last." Dabney then wrote a personal letter to McBryde detailing the progressive changes the Virginia A\&M board was about to implement, and recommending Vawter as a board rector of unusual talent. Dabney stated that Vawter was “... the leading spirit among those who planned to make the school a straight out agricultural and mechanical college of the right kind." Vawter then received additional testimonials as to McBryde's sterling qualifications. Vawter and a group of board members interviewed McBryde in Richmond on April 28, 1891, which led to the board unanimously electing McBryde president on May $7,1891 .^{273}$

McBryde assumed his office on July first and was immediately faced with a crisis.

Martin P. Scott and W. H. Graham, two of the professors whom the board had fired in their April meeting, sought to be reinstated. When that action met with failure, they presented written charges against the board to the Virginia Senate Sub-Committee on Public Instruction and Education. Their complaints were numerous; in general, Scott and Graham charged that the board had illegally spent Morrill Act funds to erect an electric light plant, a boiler house, and a

\footnotetext{
272 Mary Rawlings, The Albemarle of Other Days (Charlottesville: Michie Company, Publishers, 1925), 118.

${ }^{273}$ Kinnear, 135, 143.
} 
smokestack to supply the electric light plant with power. Additionally, Scott and Graham charged that the board had used Morrill funds to build a water supply plant and lay water lines throughout the campus. ${ }^{274}$

\section{Faculty Members Charge Vawter with Malfeasance}

The chief culprit in this charge was Vawter, who had used his relationship with Thomas Edison and his company to negotiate the construction of the electric light plant. Furthermore, Vawter had overseen the construction of a central water supply and distribution system at Virginia A \&M similar to the system he had installed at Miller Manual. Vawter knew that in addition to the college's daily water needs, a sanitary and dependable water supply was essential if typhoid, cholera, and other water-borne diseases were to be avoided. ${ }^{275}$

The General Assembly created a joint investigative committee to examine the charges. Their work revealed that the Virginia A\&M board had acted in a legal and proper manner, without bias, and that the board's actions were essential to the welfare of the school. Vawter stated that the board was solely motivated by a desire to make the college into a high-grade school of technology. All board members were firm in their written and oral testimony, and Rector Vawter was especially convincing in his oral and written presentations. Stating that he was the first person to erect an electric power plant in the South, Vawter freely admitted that he had used his Edison connection to get the Blacksburg plant installed at the college. ${ }^{276}$

Vawter retorted that it would be very difficult for the college to teach the emerging principles of power-plant operation and the applications of electricity without a power-plant. He

\footnotetext{
${ }^{274}$ Ibid., 135-136.

${ }^{275}$ Ibid., 135-136.

${ }^{276}$ Ibid., 135-136. As stated earlier in this study, Vawter was actually the second person to erect such a plant in the South as a cotton mill in Georgia installed such a few months before Vawter did so at Miller Manual. However, it is unlikely that Vawter was aware of the cotton mill's electric installation.
} 
continued that he had observed the wasteful system previously employed of hauling needed water throughout the campus on mule drawn carts. He stated, “...that everyone ought to know that it was much cheaper to let water run in a pipe than it was to haul it."277

Scott and Graham had also charged that Vawter and the board had allowed Professor Theo. P. Campbell to leave for Europe before the close of the 1890-1891 session and had paid him while absent for services not performed. Vawter's defense of this action is an example of the progressive approach that he and the board were taking in their work to build an effective faculty. Vawter declared that Campbell was a "pretty square-speaking first class fellow." Vawter related the following to the investigative committee:

Campbell approached me one day and stated, "Captain Vawter, I want you to tell me what you think of me as a professor at Blacksburg College." I answered, "You have asked me a square question, and I will give you a square answer. I think you are a fine teacher and I think you are a fine gentleman; I think your influence there is for the building up of the College, but I do not think you know enough about modern languages to be a professor of modern languages." Campbell then thanked me and asked, "Would you advise me to resign?" I replied, "No, I would not. If I were in your place, I would fit myself in the best way; I think I would go to Europe and spend the summer there where you could talk the language." Campbell took my advice and immediately requested a leave of absence to study in Europe during the following summer. His leave was granted and he departed two months before the end of the academic year. The board paid him for those two months. 278

Vawter then stated that Campbell deserved to be paid and that numerous other colleges had similar practices to help elevate their faculties. Since Campbell had spent the summer preparing to be a better instructor, Virginia A\&M would get its money back. Vawter continued, "I am willing to stand for that; charge it to my reputation." Vawter's assessment met with the investigative committee's approval. ${ }^{279}$

\footnotetext{
277 Kinnear, 135-136.

${ }^{278}$ Ibid., 137-138.

${ }^{279}$ Ibid., 138. After completing his study in Europe, Campbell returned to Virginia A\&M and served the college as professor of modern languages, and later as an academic dean, then dean of the college, and finally as the dean of the faculty for a combined total of almost forty years.
} 
This entire affair can be seen in hindsight as a positive development for the Blacksburg school. The General Assembly members involved in the investigation developed a profound respect for Vawter and his fellow board members. They saw that this board, under Vawter's leadership, had a clear plan of action. They had defined the school's mission, they had designed a structure to achieve that mission, and they had hired a president and the nucleus of a faculty fully competent to move the college forward towards that mission. Vawter was especially effective in getting the investigative committee to come to the following realization without actually stating the obvious -- any failure for Virginia A\&M to move forward would be the result of carping and further legislation interference. ${ }^{280}$

On March 1, 1892, the Senate of Virginia adopted without dissent a resolution stating that the Virginia A\&M Board of Visitors had acted properly and that the Senate had full confidence in the board's ability. McBryde had arrived in Blacksburg at the proper time. He had a stalwart rector, a unified and competent board, and the freedom from political assault that was never enjoyed by any previous president. ${ }^{281}$

\section{McBryde and Vawter Reorganize the Virginia Tech Academic Program}

Upon his appointment as president, McBryde began to plan the reorganization of the Virginia A\&M curriculum as requested by the Board of Visitors. McBryde completed his plan and submitted it to the board for their review in July of 1891. As reported earlier, in March of 1886, shortly after his appointment to the Board of Visitors, Vawter and his fellow board member J. D. H. Ross had stated the pragmatic, progressive belief that Virginia A\&M should

\footnotetext{
${ }^{280}$ Ibid., 138.

${ }^{281}$ Ibid., 139-141.
} 
provide its students with a "broad, liberal, practical, industrial education in the line of agriculture and the mechanic arts.” McBryde's plan called for just such a system. ${ }^{282}$

The program would consist of seven four-year courses of study, all of which led to a Bachelor of Science degree. All seven would be grouped into one of two columns - agriculture and mechanics. Under agriculture, a student would have the option to earn a B.S. degree in agriculture, horticulture, or applied chemistry. Under mechanics, students could earn B. S. degrees in civil engineering, mechanical engineering, electrical engineering, or general science. All students had specific distribution requirements that had to be met over the course of four years, which provided for a broad liberal education. These required courses were: mathematics, English, history, inorganic chemistry, physiology, French or German, ethics, political economics, bookkeeping, and psychology. Laboratory work was required in every department as were compositions, research papers, and other written assignments in all English, history, and modern language classes. ${ }^{283}$

McBryde, with Vawter's encouragement, also put into practice a series of entrance requirements for student applicants. Starting in 1891 a student seeking admission as a freshman was required to take a series of examinations to prove proficiency in English grammar, the History of the United States and Virginia, physical geography, arithmetic, and elementary algebra. A few years later, McBryde with the board's approval, raised the entrance standards by requiring proficiency in Latin grammar and two books of Caesar. Then in 1898, the year before Vawter resigned from the Board of Visitors, McBryde finally eliminated the preparatory department, a step Vawter had been advocating since his appointment to the board in $1886 .{ }^{284}$

\footnotetext{
282 Ibid., 139.

${ }^{283}$ Ibid., 146-147. See also Wallenstein, 74 and Cochran, 164.

${ }^{284}$ Cochran 179-180.
} 
This move to enact and enforce entrance requirements and close preparatory departments was a trend developing at a number of institutions during the Progressive Era. Sophie Newcomb and Vassar closed their preparatory departments in 1887 and 1902 respectfully. The University of California, Michigan, and Wellesley all developed entrance standards during this era. ${ }^{285}$

Vawter and the board adopted McBryde's plan later in July and upon acceptance and implementation, McBryde's plan became the foundation for the modern Virginia Polytechnic Institute (VPI). The board's adoption of McBryde's plan was the first time that a Virginia A\&M board allowed the school to operate under a plan drawn up by the president and the faculty. All previous boards had interfered with such operations and jealously guarded the power to meddle whenever they wished. Vawter played a key role in this positive development as he oversaw a similar curriculum at the secondary level at Miller Manual. Thanks to Vawter, McBryde could not only plan the curriculum but also hire the faculty. Additionally, McBryde was the first Virginia A\&M president to be made a member of the Board of Visitors. McBryde was also aided by the passage of both the Hatch Act and the Second Morrill Act of 1890. These acts more than doubled the money available to operate the college. ${ }^{286}$

\section{Vawter's Role in the Renaming of the Blacksburg College}

The adoption of McBryde's program led Vawter, the board, McBryde, and members of the General Assembly to question whether the school's name was still appropriate. The name Virginia Agricultural and Mechanical College omitted any reference to instruction in the scientific technologies. Because of the fire of February 1900, which destroyed irreplaceable board minutes, we may never know who proposed the change to Virginia Agricultural and Mechanical College and Polytechnic Institute, but surviving personal letters and other

\footnotetext{
${ }^{285}$ Gordon, 168-169.

${ }^{286}$ Kinnear, 146-147.
} 
circumstantial evidence indicate that the change was suggested by Charles Vawter. In any case, a bill was introduced in the General Assembly to change the school's name to that listed above, and the bill passed and signed into law on March 5, 1896. It was understood at the time that the words "agricultural" and "mechanical" had to be included in the school's title in order to continue receiving the annual federal grants. Nevertheless, the name was immediately shortened to Virginia Polytechnic Institute, which was frequently shortened to Virginia Tech, or often just VPI. ${ }^{287}$

The work regarding VPI's name change was the last major contribution Charles Vawter made as Rector of the VPI Board of Visitors. By the end of the decade his health was beginning to fail and travel to Blacksburg, Richmond, and other sites of board meetings had become difficult for him. These difficulties led Vawter, whom Duncan Kinnear called McBryde's "tower of strength," to resign from the board in $1899 .{ }^{288}$

Looking back at Vawter's work at VPI, Kinnear's words are appropriate. Vawter's close relationship with the leaders of the Virginia Democratic Party helped remove the meddlesome influence of politicians who interfered with the school's operations for personal political gain. Also, Vawter's confidence and his analytical mind served the college well when confronted with the Scott-Graham investigation by the state senate committee. Finally, as a pragmatic progressive educator with a wealth of personal educational administrative experience, Vawter played a key role in McBryde's reorganization of VPI and is often credited with suggesting the school's name change. Vawter's positive influence was also recognized by the VPI student body, who showed their appreciation for his work by dedicating the school's yearbook, The

\footnotetext{
${ }^{287}$ Ibid., 162-163.
}

${ }^{288}$ Ibid., 165. 
Bugle, to Vawter in $1900 .{ }^{289}$ It is not surprising that Virginia Tech named a dormitory after Charles Vawter -- on May 16, 1966 Vawter Hall was dedicated. ${ }^{290}$

In his work at several Virginia schools, Charles Vawter was a progressive educator who believed that students of all socio-economic classes deserved a chance to study the classical curriculum while also learning skilled labor tasks. He was also a pragmatic educator who was willing to experiment with new technologies. This can be seen in his work with Edison at Miller Manual as well as at both Virginia Tech and Virginia State. Further, Vawter was willing to support programs he believed were appropriate even when such programs put him in conflict with politicians and faculty. A prime example of such is Vawter's demand that the University of Virginia maintain its engineering program. Undoubtedly, education in Virginia has been deeply impacted by the work of Charles Vawter.

${ }^{289}$ Charles E. Vawter Family Collection, Special Collections the Newman Library Virginia Tech.

${ }^{290}$ Retrieved August 5, 2014 from http://www.vt.edu/about/buildings/vawter-hall.html. See also Wallenstein, 210. 


\section{Chapter Six}

\section{Reconsidering Progressive Education in Our Time}

Socio-political movements tend to spawn opposition groups, and Progressivism was no exception. Undoubtedly, Progressivism produced many positive developments. The Sixteenth Amendment provides for a progressive income tax that helped curb the income disparities of the Robber Baron Era. The Seventeenth Amendment expanded the electorate by providing for the popular election of U.S. Senators who had previously been selected by the wealthy state legislators. Although the Eighteenth Amendment's attempt to prohibit the social consumption of alcohol proved disastrous, the Nineteenth Amendment granted the right to vote to women who now vote in greater numbers than men. Progressivism's advancements, however, were not just limited to changes in the federal constitution. Many other positive changes occurred legislatively and socially, and certainly the types of progressive educational changes described in this study improved the lives of millions of American students.

Despite these laudable achievements, opposition to the Progressives in general and Progressive Education in particular developed. The First World War and the economic downturn which followed the war led many to question the guiding principles of Progressive Education. The presidential and congressional elections of 1920 clearly showed that the electorate was no longer moved by activism. The progressive battle cry of the "people versus the interests" no longer stimulated the populace. Rather, the national mood had turned resentful and disillusioned. Wilson's Fourteen Points and the League of Nations were viewed as idealistic folly. Increasingly, the public began to question the wisdom of Progressivism in general and Progressive Education in particular. 
In this final chapter, I will describe how a century after Progressivism's decline we are witnessing the revival of many of the guiding principles of the Progressive Era. There has been a significant improvement in race relations since the days of Jim Crow discrimination, and Barack Obama has become the first African American president. However, racial prejudice and discrimination are all too common. Racial discrimination still pervades many aspects of American society, including how we educate young people. I will describe both our educational successes and where we as a society still fall short of racial equality in our schools and colleges.

Additionally, I will comment on the continuing issue of whether we should educate using a liberal curriculum or whether we should present students with an education that will enable them to earn a living by practicing skilled trades? Finally, I will describe how educators are abandoning the standard methodology of the past 100 years, whereby students sit in desks aligned in rows, listen to teacher lectures, and are graded by repeating the instruction through objective test methodologies such as multiple choice, matching questions, and fill in the blanks. Today there is a steady adoption of the group work, portfolio building, and instructor-as-mentor that characterized Charles Vawter's work at Miller Manual as well as the work of John Dewey and many other progressives.

\section{Racial Discrimination in Our Era}

In 1954 the U.S. Supreme Court rendered the landmark Brown vs. Board of Education verdict. This verdict declared racial segregation of the schools to be a violation of the Fourteenth Amendment's Equal Protection clause. The court followed this verdict a year later by ruling that school boards should proceed with "all deliberate speed to desegregate public schools at the earliest practical date." However, with the exception of certain high-profile cases, this verdict was ignored until federal courts in the late 1960s began to order the integration of public schools. 
This led to a relatively brief period when young black and white students shared school classrooms, dining halls, restrooms, locker rooms, playing fields, and other facilities.

Sadly, whereas Brown stimulated a civil rights movement that desegregated many facets of American society, it was not so successful in integrating education. The initial school integration gains that did happen were quickly followed by white families moving out of American cities into the suburbs. This phenomenon, known as "White Flight," created a situation where most urban school student bodies became predominantly black. Unfortunately, the legal or de jur segregation of the Jim Crow Era, has been replaced by the de facto segregation of the last half century where the different races remain segregated because of factors other than legal codes.

White Flight eventually led the Supreme Court to hear the case of Swann v. CharlotteMecklenburg Board of Education, 402 U.S. 1 (1971), in which the Court held that “... busing is an appropriate remedy for the problem of racial imbalance in schools, even when the imbalance resulted from the selection of students based on geographic proximity to the school rather than from deliberate assignment based on race." This was done to ensure the schools would be "properly" integrated and that all students would receive equal educational opportunities regardless of their race. ${ }^{291}$ The national response from the white community to this decision was immediate and emotionally negative. Soon race riots broke out in Boston and other cities as white parents took to the streets to prevent their children from going to school with black children.

In the Swann case, the Court ruled that when the Charlotte-Mecklenburg school system reached the point that it became a unitary system, forced busing to achieve racial integration

${ }^{291}$ Retrieved November 1, 2016 from https://www.oyez.org/cases/1970/281 
could then end. This was the loophole that allowed the Fourth Circuit Federal Appeals Court in Richmond, Virginia in 2000 to declare that forced busing was no longer necessary. This verdict was followed by the U.S. Supreme Court refusing to hear an appeal from the Fourth Circuit, thus upholding the Fourth Circuit's verdict. The Fourth Circuit's ruling led to the abandonment of forced busing across the United States. ${ }^{292}$

Today the typical black student attends a school where only $29 \%$ of the student body is white, and in many communities the percentage of black students is closer to $100 \% .{ }^{293}$ Additionally, the percentage of students enrolled in many districts that are "low income," based on their eligibility for free or reduced cost lunch, is often $80 \%$ or higher. In Baltimore, for example, that percentage figure is $84.8 \%,{ }^{294}$ and at Petersburg High School in Virginia the percentage of black students is $98 \% .{ }^{295}$ Nevertheless, black student achievement, nationwide and in every state, has improved at a spectacular rate since Brown. Yet because average white achievement has also improved, the gap between black and white achievement remains a troubling issue. The average black student still performs better than only about 25 percent of white students, making the goal of equal qualification for the labor market a distant marker. Additionally, many of these children's parents have less educational attainment and lower literacy levels, so the children hear less complex language at home and are read to less frequently, all of which has a negative impact on their educational achievement. This is based on research that indicates that the most important predictor for young children of later academic success is the general background knowledge with which they come to school. ${ }^{296}$

\footnotetext{
292 Ibid.

${ }^{293}$ Retrieved November 1, 2016 from http://www.epi.org/publication/brown-at-60-why-have-we-been-sodisappointed-what-have-we-learned/.

${ }^{294}$ Retrieved November 1, 2016 from http://www.baltimorecityschools.org/about/by_the_numbers

${ }^{295}$ Retrieved November 1, 2016 from http://www.publicschoolreview.com/petersburg-high-school-profile/23805

296 Ibid.
} 
Today many private schools have more integrated student and faculty populations than public schools that are restrained by local and state political factors. Furthermore, many private schools have the financial resources to create and mentor diverse student bodies. This is certainly true at today's Miller School. The twenty-fifth clause of Samuel Miller's will calls for the establishment of a school for the "poor, white children of Albemarle County." For most of the school's first century it operated as an all-white institution, however since the 1960s black students have attended the Miller School. Today the student body is diverse with over ten percent black, twenty percent Asian, six percent Hispanic or Latino, and sixty-four percent white. Additionally, students from sixteen different countries are included in the 2016-2017 student body. Furthermore, more than twenty-five percent of the student body receives needbased financial aid.

Today, black students at Miller room with both white Americans and students from Asia, Europe, Africa, and Latin America. Over the past several years many of these black students have matriculated to a range of universities. Current African-American alumni are enrolled at schools as diverse as Brown University, Dartmouth College, Virginia Commonwealth University, the University of Virginia's College at Wise, the New Jersey Institute of Technology, Hood College, North Carolina A\&T, Christopher Newport University, and the College of Wooster. Many of these students attended Miller on various degrees of need-based financial aid and often received support from the school's Director of College Placement in filling out and submitting their FAFSA ${ }^{297}$ applications when such work was beyond the capabilities of their parents.

${ }^{297}$ FAFSA stands for Free Application for Federal Student Aid; for more information see https://fafsa.gov/ 
However, this researcher does not view private schools as the solution to our national problem of under achievement by racial minorities and poor whites. The solution is to properly fund both our public schools and pre-school programs, as well as eliminating or curbing many programs that are ineffective such as the emphasis on high stakes testing. This will require not only the raising of many different types of taxes but also the closing of many tax loopholes and shelters that benefit powerful individuals and corporations. To accomplish this requires political power, which is a strength that is in short supply among disadvantaged populations. To develop political power will require a number of factors.

Black Americans, Hispanics, and Asian Americans, are not likely in the near future to have the demographic numbers to offset the growing racial backlash by white Americans who feel displaced by socio-economic factors beyond their control. Demographers predict that by mid-century America will become a minority-majority country. Will that development change the racial equation? Another question involves young Americans -- will the millennial generation play a role in bringing about more racial justice? Only time will tell. While millennials are the most racially inclusive generation in American history, will they remain so as they age, or will they develop the same prejudices about race that have been the hallmark of American society since colonial times?

\section{Liberal versus Industrial Education in Our Era}

In addition to the same issues of race that characterize both the Progressive Era and twenty-first century America, another parallel involves the question of what type of education our schools should provide. In the Progressive Era, the debate concerned industrial versus liberal education. We are having the same debate in this second decade of the twenty-first century, only today it is more nuanced. In 1984 Congress passed and President Ronald Reagan signed into law 
the Carl D. Perkins Career and Technical Education Act. The act was named after a long serving House member from Kentucky who championed vocational education until his death in 1984. Subsequently, the act has been amended and strengthened in 1990, 2002, and $2006 .^{298}$

The act, which is overseen by the Department of Education, defines vocational-technical education as “...organized educational programs offering sequences of courses directly related to preparing individuals for paid or unpaid employment in current or emerging occupations requiring other than a baccalaureate or advanced degree." The act also stipulates that vocational technical programs teach higher-order reasoning skills, problem solving skills, and specific occupational training skills that will enable the student to gain meaningful employment and be able to function in today's highly technical world. The act is a principal source of federal funding to states and their school districts for secondary and postsecondary career and technical education programs ${ }^{299}$.

Today's public school vocational education is far different from the type of training that was practiced at both Hampton and Tuskegee and championed by the White Architects of Black Education. In fact, it is very similar to what Charles Vawter designed and put into practice at Miller Manual in the last decades of the nineteenth-century, and what John Dewey managed at his Lab School in Chicago. It is also what W. E. B. Du Bois supported throughout his long career and is very similar to what he observed during his trip to Germany in 1935.

In Virginia, the Charlottesville Albemarle Technical Education Center (CATEC) is a local example of the twenty-first century's new-found enthusiasm for Progressive Education. CATEC offers both high school students and adults in Charlottesville and Albemarle County a combination of the classical curriculum with hands-on training in a number of career fields.

\footnotetext{
${ }^{298}$ Retrieved October 25, 2016 from http://www2.ed.gov/offices/OVAE/CTE/perkins.html

${ }^{299}$ Retrieved October 25, 2016 from http://cte.ed.gov/legislation/about-perkins-iv
} 
Career training is offered in nursing, pharmaceuticals, dental assistance, automobile repair, heating-ventilation-air conditioning (HVAC), the building trades, culinary arts, firefighting, music technology, and a number of other fields. High school students spend half of their day at their school and the other half at CATEC. At their high school, they must complete the standard school credit requirements, and at CATEC they receive both hands-on and classroom instruction. For example, a student who wants to become an electrician will receive classroom instruction at CATEC in the dynamics of electricity as well as the various code books that stipulate how home and commercial wiring is mandated. They will also have hands-on exercises where they will be required to construct various types of electrical circuits. ${ }^{300}$ As related earlier in this study, Miller Manual students performed similar exercises during the Vawter Era.

Adults who want to gain technical skills are also enrolled at CATEC. For example, an adult who wants to have a career as a journeyman electrician can take night classes at CATEC. After passing CATEC's exam, the student receives a journeyman's certificate. The student can then go to work for an electrical contractor. After a specific apprenticeship and after passing additional examinations administered by CATEC, the student will receive a license as a master electrician. CATEC offers similar opportunities for adult students in a range of other fields. ${ }^{301}$

But not only are public schools returning to many of the practices of Progressive Education. Numerous private schools have instituted cooperative learning classrooms and put into practice programs that are nearly identical to Manual Training Education. For example, at the Miller School of Albemarle, an Applied Engineering program has been developed which gives students the opportunity to concentrate on the many facets of the engineering field.

\footnotetext{
${ }^{300}$ Retrieved November 10, 2016 from https://www.catec.org/category/programs-for-students/. Personal interview by Hugh Meagher with Brad Lovelace who is a graduate of the CATEC program.

${ }^{301}$ Ibid.
} 
Students take foundational coursework in calculus, physics, chemistry, and "design/build." Design/build utilizes Miller's state of the art wood shop and CAD ${ }^{302}$ capabilities to build structures, craft bowls on lathes, and build cars, grandfather clocks, and numerous other items.

Additionally, students receive hands-on experience through membership and participation in a variety of engineering groups, as well as field trips to the engineering departments of the University of Virginia and Virginia Tech. ${ }^{303}$ The Applied Engineering Program requirements have been established to reward students who take advantage of Miller's many curricular and extracurricular opportunities. Each student chooses a unique course of study, earning credits toward a goal of 20 total credits to receive the Applied Engineering Program certificate. ${ }^{304}$ Examples of the types of courses earning credit are AP Physics, AP Chemistry, AP Calculus AB and BC, Design/Build, Land Management, Computer Programming, and Robotics. ${ }^{305}$

The Miller School Applied Engineering students are engaged in numerous hands-on projects. For example, they are restoring the hydroelectric plant that was built on the Miller campus that housed Thomas Edison's dynamos in the 1880s and which produced the school's electric power until after World War Two. The Miller Power House had fallen into disrepair in the years since its last use. Under the leadership of the Director of Applied Engineering, Ryan Henry, the students have cleaned both the outside and the interior of the building. They have repaired over 144 window glass panes as well as the wooden double-hung window frames. This

\footnotetext{
${ }^{302} \mathrm{CAD}$ as an acronym for Computer Assisted Design; this is an architectural drafting software program.

${ }^{303}$ For example, the University of Virginia's Engineering Department helped Miller create a chapter of the Society of Women Engineers (SWE).

${ }^{304}$ Miller School of Albemarle Profile for 2016-2017

${ }^{305}$ Ibid.
} 
has involved the skilled use of routers and other wood shop machines, and the cutting of glass and its installation.

They are presently building the wooden frames for the concrete pours, which will replace the badly deteriorated concrete steps into the building. They are also engaged in a number of other repair projects. They have repaired the Norfolk Veneer plaster of the building's interior masonry walls, as well as the bead and baton interior ceiling. Over the past year, they have fixed the hydroelectric dynamo so that it is now spinning. Soon they plan to install a new generator. The spring fed water lines to the Power House no longer have the 800 gallons of water per minute that formerly allowed the Power Plant to produce twenty-five kilowatts of electricity. Today's reduced flow is only capable of two-and-a -half kilowatts. However, that is enough to power two standard size houses. The student's goal is to turn the Power House into a coffee shop for the campus community that will operate entirely on its own power. ${ }^{306}$

In all of this work the students have been charged with studying and exploring all of the technical issues involved. Ryan Henry has led them but not given them the answers to the complicated engineering problems. Additionally, in their classwork the students in their physics classes have been studying both Newton's Laws and the Theory of the Conservation of Movement. Thus one of their recent assignments was to write a 250-word paper explaining how Newton's Laws and the Theory of the Conservation of Movement are used to spin the Power House's dynamo. ${ }^{307}$ Thus we see educational pedagogy in the twenty-first century bearing the stamp of Progressive Education - a combination of liberal and industrial educational doctrines that makes use of both traditional classroom instruction by teachers and texts combined with the hands-on construction of specific items taught by the instructor and the texts.

\footnotetext{
306 Interview by Hugh Meagher with Ryan Henry November 11, 2016.

${ }^{307}$ Ibid.
} 


\section{The Changing Pedagogy of the Twenty-First Century}

During the Progressive Era educators debated the topic of the type of instruction that should be used to educate children. Traditionalists argued for classrooms that were segregated by age and levels of accomplishment. They were also firm supporters of instruction by lectures delivered by teachers and assessment by written tests that combined objective and subjective questions. Whereas Progressives like Vawter, Dewey, and Du Bois used non-traditional classrooms that included nearby fields, streams, and lakes, they also inculcated knowledge through classroom instruction and hands-on activities and group projects. There is much evidence that these methodologies were successful for Vawter, Dewey, and others of their type, but most of these methods were abandoned by the 1920 s.

For most of the twentieth-century, the norm in both public and private school was the teacher lecture before a classroom of passive students sitting quietly in rows of desks followed by an objective assessment. Often the assessment was then graded by a scantron machine. Many educational researchers believe that this factory-like atmosphere destroys creativity in students. The British author, speaker and international advisor on education in the arts to government, Ken Robinson, makes the case that our school paradigm destroys creativity. Robinson believes the traditional school model has the goal of producing good workers rather than creative thinkers. Robinson argues that students with restless minds and bodies -- far from being cultivated for their energy and curiosity -- are ignored, medicated with ADHD drugs such as amphetamines, or even stigmatized as undisciplined trouble-makers, which often results in psychic damage to the student. ${ }^{308}$

\footnotetext{
${ }^{308}$ Retrieved on November 22,2016 from https://www.ted.com/speakers/sir_ken_robinson
} 
Robinson makes the case that to succeed in today's fast-changing, highly technical world, education has to evolve on three fronts. Education needs to foster diversity by offering a broad curriculum and promoting individualization of the learning process. Additionally, schools should promote curiosity through creative teaching, which depends on high quality teacher training and development. Finally, Robinson argues that boards of education “....should focus on awakening creativity through alternative didactic processes that put less emphasis on standardized testing, thereby giving the responsibility for defining the course of education to individual schools and teachers." He believes that much of the present education system in the United States fosters conformity, compliance, and standardization rather than creative approaches to learning. ${ }^{309}$

\section{The Flipped Classroom}

A twenty-first century development that allows individual schools and teachers to define the course of education is the flipped classroom. The flipped classroom is a pedagogical model in which the typical lecture and homework elements of a course are reversed. Short video lectures are viewed by students as part of their homework before the class session, while in-class time is devoted to exercises, projects, or discussions. Additionally, the homework is reviewed by the teacher at the start of each class, which enables the teacher to assess problems with comprehension. The teacher then spends the class working individually with students to help them with their mastery of that day's material. The teacher acts as a coach or as an advisor while encouraging students in individual inquiry as well as encouraging them to work collaboratively. 310

\footnotetext{
309 Ibid.

${ }^{310}$ Retrieved on November 22, 2016 from https://net.educause.edu/ir/library/pdf/eli7081.pdf
} 
The video homework is either created by the teacher or selected from an online repository. The ease with which the video can be accessed and viewed fits the learning style of today's visual learners. Therefore, the flipped classroom draws on such concepts as active learning, student engagement, hybrid course design, and course podcasting. The value of a flipped class is in the repurposing of class time into a workshop where students can inquire about lecture content, test their skills in applying knowledge, and interact with one another in hands-on activities. $^{311}$

Many public and private schools are experimenting with this style of instruction, and it is also frequently used by colleges and universities. At the Miller School of Albemarle, it is used by the school's mathematics department. The chair of Miller's math department, John Macdonald has created hundreds of hours of these short instructional videos and accompanying assessments. The students visit his department's website at http://mathscribble.blogspot.com/p/geometry-syllabus.html to access their instruction and homework. By clicking on active links, the student is then taken to various YouTube videos for their instruction. This can be viewed at https://www.youtube.com/watch?v=Vdv6tgWJFEw .

This pedagogy has been used by Macdonald for only about four years, so it is too soon to draw any longitudinal assessment of whether it is responsible for the improving SAT and ACT math test scores achieved by the school's students. There are too many other factors that may be playing a role in such an improvement -- for example, the school has seen an increase in the number and quality of applicants.

However, it is clear that Macdonald's students have a more active role in his classroom compared to when he used traditional methods. ${ }^{312}$ It is also interesting to realize how closely the

\footnotetext{
311 Ibid.

312 Interview by Hugh Meagher with John Macdonald November 17, 2016.
} 
flipped classroom models the type of instruction that was used in the school's workshop classrooms during the Vawter Era. The same can be said of other Progressive Era classrooms such as John Dewey's at Chicago.

\section{The Future of High Stakes Testing}

Late twentieth and early twenty-first century educational administrators and politicians place high value on high-stakes testing, which is usually assessed by multiple-choice exams. Notable examples of this style of testing are the Virginia Standards of Learning (SOLs), the Florida Next Generation Sunshine State Standards (NCSSS), and on the national level, the legislation known as No Child Left Behind (NCLB). Supporters of this style of assessment cite concerns involving how United States' students compare with foreign students on various benchmark testing, especially testing involving mathematics and science.

In the best known international assessment of achievement by students categorized by geography, known as the Programme for International Student Assessment (PISA), the U.S. doesn't make it on the list of the top 25 geographical entities in math or top 15 in reading. In descending order from the top spot in math, they are (1) Shanghai, (2) Singapore, (3) Hong Kong, (4) Taipei, (5) Korea, (6) Macao, (7) Japan, (8) Lichtenstein, (9) Switzerland, and (10) the Netherlands. Most of these geographical entities are also posting top-of-the charts reading scores. ${ }^{313}$

Many critics believe that the U.S. suffers when compared to these competitors because America has higher poverty and racial diversity than many of the above listed entities. Socioeconomic background has a significant impact on student performance in the United States, with some $15 \%$ of the variation in student performance explained by this factor. Although this impact

\footnotetext{
${ }^{313}$ Retrieved on November 23, 2016 from https://en.wikipedia.org/wiki/Trends_in_International_Mathematics_and_Science_Study
} 
has weakened over time, disadvantaged students show less engagement, drive, motivation and self-beliefs. Only $50 \%$ of U.S. students agreed that they are interested in learning mathematics, which falls below the average of the above listed entities. ${ }^{314}$

These results have led many politicians and educators to conclude that the United States needs to revamp both its school curriculum to include more Science, Technology, Engineering, and Mathematics (STEM), and to require a battery of testing methodologies to assess how much of this STEM curriculum is retained by students. This has led to the creation of the types of high stakes testing championed by Virginia Governor George Allen (the SOLs), Florida Governor Jeb Bush (the NCSSS), and at the national level, the NCLB testing championed by President George W. Bush. These supporters argued that these methodologies would raise all socio-economic groups to levels that would enable American students to prosper in the twenty-first century world.

When these proposals were introduced, many educational researchers countered that these "one size fits all" methodologies were doomed to failure. They argued that the diversity of the American student population requires that more individualized learning plans be developed for the range of different student needs. Noted University of Virginia educational researcher, Daniel Duke, who teaches at the University's Curry School of Education, has referred to the SOL-NCLB style programs as the "last gasp of a dying paradigm." 315 A decade or more after the implementation of these forms of high stakes testing there is considerable evidence that Daniel Duke may be right. U.S. students are doing no better on international benchmarks like the PISA assessment, and drop-out rates have remained stubbornly high in many American school districts.

\footnotetext{
${ }^{314}$ Ibid.

${ }^{315}$ Notes from Dr. Duke's class in Organizational Theory EDLF 877. Fall 2003.
} 
Every year over 1.2 million students drop out of high school in the United States. This amounts to a quarter of American high school students failing to graduate from high school on time. The end result is the U.S. ranks $22^{\text {nd }}$ out of the 27 developed countries by this matrix. ${ }^{316}$ Many critics of NCLB contend that the legislation has resulted in unfunded federal mandates, which essentially passes financial problems from the federal government to state and local governments with the burden of paying for the program placed at the state and local level. Finally, detractors allege that the law places too much emphasis on standardized testing and stringent teacher qualifications. ${ }^{317}$

Another common criticism of NCLB is that the program forces teachers to "teach to the test" in order to get students to pass the standardized exams. These critics say that a consequence of teaching to the test is that teacher creativity and student learning are stifled. Moreover, critics charge that it is unrealistic to expect learning disabled students and non-English speaking students to pass the test. The National Education Policy Center (NEPC), at the University of Colorado Boulder, stated in February of 2015 that “... there is no evidence that any test score increases represent the broader learning increases that were the true goals of the policy - goals such as critical thinking, the creation of lifelong learners, and more students graduating high school ready for college, career, and civic participation." ${ }^{318}$

Additionally, NCLB's annual tests were supposed to track the annual progress of students in reading and math proficiency. The testing results are displayed on publically disclosed school report cards for parents, administrators, and lawmakers to see, and if an individual school is not

\footnotetext{
${ }^{316}$ Retrieved on November 25, 2016 from https://www.dosomething.org/us/facts/11-facts-about-high-school$\underline{\text { dropout-rates }}$

${ }^{317}$ Retrieved on November 26, 2016 from http://education.findlaw.com/curriculum-standards-schoolfunding/criticism-of-no-child-left-behind.html

318 Retrieved on November 26, 2016 from http://www.businessinsider.com/heres-what-no-child-left-behind-gotwrong-2015-3
} 
making improvement, punitive measures are triggered. These punitive measures can mean less funding for schools that do not meet these annual benchmarks and outright takeovers by the state government for the most egregiously failing schools. Opponents think that these punishments are patently unfair in that they target only certain players in the system.

The NEPC argues: "Holding teachers accountable but excusing the policymakers who fail to provide necessary supports is as harmful and illogical as holding students accountable but excusing poor teaching." ${ }^{119}$ The end result is that many students complain that the emphasis on high stakes testing has made school both dull and demoralizing, which has led parents, educational researchers, and politicians to question the wisdom of huge budgetary outlays for such types of curriculum and styles of testing.

These concerns have led a growing number of localities and states to refuse to adhere to the NCLB standards and willingly forfeit the federal funding that their refusals trigger. Another result is a growing movement by American parents to enroll their children in private schools that are exempt from the high-stakes testing mandates. Furthermore, NCLB has led a number of nonparticipating public schools and many private schools to experiment with methodologies that originated in the Progressive Era of Education. These include group work, portfolio building, and hands-on construction of objects previously studied in student classwork.

\section{Conclusion}

We live in an era of dramatic change and this is certainly the case with education. Many of the same issues that progressives argued over in the late nineteenth and early twentieth centuries are being re-debated. These include the issue of how do Americans create schools that are not only open to all races and ethnicities but also schools that provide all students with the

${ }^{319}$ Ibid. 
skills needed to be productive and contributing members of society. These debates also involve curriculum and pedagogical questions.

Many players debate whether the classical curriculum of mathematics, the natural sciences, language arts, the social sciences, and foreign language study is appropriate in our highly technical world. These contrarians believe that the emphasis should be placed on technical studies known as STEM. They are countered by others who argue that democratic societies cannot function without a citizenry that understands history, has been steeped in civic education, and has been encouraged to think creatively. They argue for the maintenance of the classical curriculum.

Finally, educators, politicians, parents, and students are debating how instruction should be delivered. As in the Progressive Era, many are abandoning the traditional twentieth-century classroom where students sat in rows, in passive silence, listening to teacher lectures followed by objective exams to assess rote regurgitation of the data delivered by the teacher. Instead, progressive methods such as those practiced by Charles Vawter, John Dewey, and other luminaries of the late nineteenth-century are again in vogue. This certainly is the case at the Miller School of Albemarle, where the "hands-on" methods employed by Charles Vawter have never gone out of favor. 


\section{Selected Bibliography}

Alridge, Derrick. The Educational Thought of W. E. B. Du Bois: An Intellectual History. New York: Teachers College, 2008.

Anderson, James D. The Education of Blacks in the South, 1860-193. Chapel Hill: University of North Carolina Press, 1988.

Baltimore City Schools, "City Schools at a Glance," http://www.baltimorecityschools.org/about/by the_numbers (accessed November 1, 2016).

Barranger, Anna. "Pleasant It Is to Remember These Things." Magazine of Albemarle County History 27 (1968-69): 8.

Benert, Annette. The Architectural Imagination of Edith Wharton: Gender, Class, and Power in the Progressive Era. Cranbury, NJ: Fairleigh Dickinson Press, 2007.

Brubaker, William C. Planning and Designing Schools. New York: McGraw-Hill, 1998.

Business Insider. "Three Big Ways No Child Left Behind Failed," http://www.businessinsider.com/heres-what-no-child-left-behind-got-wrong-2015-3 (accessed November 26, 2016).

CATEC. "Charlottesville Albemarle Technical Education Center," https://www.catec.org/category/programs-for-students/. (accessed November 10, 2016).

Callahan, Raymond E. Education and the Cult of Efficiency. Chicago: University of Chicago, 1962.

Chamberlain, Bernard. "Samuel Miller, 1792-1869: Albemarle Philanthropist." Magazine of Albemarle County History 28 (1970): 119-127.

Charlottesville Chronicle, August 1878. Clipping found in the Miller School of Albemarle Main Office Safe. Miller School of Albemarle Archives. Retrieved June 25, 2014.

Clauson-Wicker, Stu and Netta Smith. "Heroes and Heroines Set in Stone." Virginia Tech Magazine (Fall 1995): 3-5.

CNN Money. "The Richest Americans," http://money.cnn.com/galleries/2007/fortune/0702/gallery.richestamericans.fortune/4.html (accessed July 23, 2013).

Coates, Charles P. History of the Manual Training School of Washington University. United States Bureau of Education, Bulletin, 1923, No. 3. Washington: Government Printing Office, 1923. 
Cochran, John P. "The Virginia Agricultural and Mechanical College: The Formative Half Century, 1872-1919, of Virginia Polytechnic Institute." Unpublished Ph. D. dissertation, University of Alabama, 1961.

Cremin, Lawrence A. The Transformation of the School: Progressivism in American Education, 1876-1957. New York: Alfred A. Knopf, 1961.

Cubberley, Elwood. Changing Conceptions of Education. Boston: Houghton Mifflin, 1909. . Public School Administration: A Statement of the Fundamental Principles Underlying the Organization and Administration of Public School. Boston: Houghton Mifflin, 1916.

Curti, Merle. The Social Ideas of American Educators. Totowa, New Jersey: Littlefield, Adams \& Co., 1935.

Dewey, John. How We Think. Lexington, MA: Heath, 1933.

. The School and Society: Three Lectures. New York: McClure, Phillips, 1900.

Dewey, John and Evelyn Dewey, Schools of To-morrow. New York: Knickerbocker Press, 1915.

DO Something.org, "11 Facts About High School Dropout Rates," https://www.dosomething.org/us/facts/11-facts-about-high-school-dropout-rates (accessed November 25, 2016).

Eaton, William E., ed. Shaping the Superintendency: A Reexamination of Callahan and the Cult of Efficiency. New York: Teachers College Press, 1990.

Economic Policy Institute, "Brown v. Board at 60: Why Have We Been So Disappointed? What Have We Learned? http://www.epi.org/publication/brown-at-60-why-have-we-been-sodisappointed-what-have-we-learned/ (accessed November 1, 2016).

Edison Electric Light Co., Bulletin No. 21. New York: Edison, 1883.

EDUCAUSE Learning Initiative. "Things You Should Know About the Flipped Classroom," https://net.educause.edu/ir/library/pdf/eli7081.pdf (accessed November 22, 2016).

Engs, Robert Francis. Educating the Disfranchised and Disinherited: Samuel Chapman Armstrong and Hampton Institute, 1839-1893. Knoxville: University of Tennessee Press, 1999.

Fallace, Thomas. Dewey and the Dilemma of Race: An Intellectual History, 1895-1922. New York: Teachers College, 2011. 
Family Search, "2 $7^{\text {th }}$ Regiment, Virginia Infantry (Civil War)," https://familysearch.org/learn/wiki/en/27th_Regiment,_Virginia_Infantry_\%28Confederate\% $\underline{29}$ (accessed June 11, 2013).

Fairclough, Adam. A Class of Their Own: Black Teachers in the Segregated South. Cambridge, Massachusetts: Harvard University Press, 2007.

Find Law. "Criticism of No Child Left Behind,"

http://education.findlaw.com/curriculum- standards-school-funding/criticism-of-no-child-leftbehind.html (accessed November 25, 2016).

Freedman, James O. Liberal Education and the Public Interest. Iowa City: University of Iowa Press, 2003.

Froebel, Friedrich. Autobiography of Friedrich Froebel. London: Swan and Sonnenschein, 1891.

Gaither, Milton. American Educational History Revisited: A Critique of the Process. New York: Teachers College Press, 2003.

Google Books. Dewey, John. The School and Society. http://books.google.com/books?id=NBXL2B4OF9gC\&printsec=frontcover\#v=onepage\&q\&f =false (accessed January 11, 2013).

Gordon, Lynn D. Gender and Higher Education in the Progressive Era. New Haven: Yale University Press, 1990.

Gray, Helen. "Educating Poor White Children: The Story of a Southern Industrial School." Leslie's Weekly (April 24, 1902): 394-395. Miller School of Albemarle Archives.

Ham, Charles H. Mind and Hand: Manual Training, The Chief Factor in Education. New York: American Book Co., 1900.

Harlan, Louis R. Booker T. Washington: The Wizard of Tuskegee, 1901-1915: New York: Oxford University Press, 1983.

History News Network, "The Horrifying American Roots of Nazi Eugenics," http://historynewsnetwork.org/article/1796 (accessed August 12, 2016).

Holman, Henry. Pestalozzi: An Account of His Life and Work. London: Longman Green \& Co., 1908.

Howlett, John. Progressive Education: A Critical Introduction. New York: Bloomsbury Publishing, 2013.

Inside UVA Online. "Miler Hall Makes way for Special Collections Library." http://www.virginia.edu/insideuva/2002/19/miller_hall.html (accessed November 7, 2012). 
Israel, Paul and Jeffrey, Thomas E. eds. The Papers of Thomas Edison Vol.6: Electrifying New York and Abroad, April 1881-March 1883. Baltimore: Johns Hopkins Press, 2007.

James, William. Pragmatism and the Meaning of Truth. Cambridge, MA: Harvard University Press, 2000.

Jones, Frances A. Thomas Alva Edison: Sixty Years of an Inventor's Life. New York: Thomas Y. Crowell \& Co., 1907.

Kinnear, Duncan Lyle. The First 100 Years; A History of Virginia Polytechnic Institute and State University. Blacksburg: Virginia Polytechnic Institute Educational Foundation, Inc., 1972.

Martin Luther King, Jr. and the Global Freedom Struggle. "Black Power." http://kingencyclopedia.stanford.edu/encyclopedia/encyclopedia/enc_black_power/

McCandless, Amy T. The Past in the Present: Women's Higher Education in the Twentieth Century American South. Tuscaloosa: University of Alabama Press, 1999.

Meier, August. Negro Thought in America: 1880-1915.Ann Arbor: University of Michigan Press, 1988.

Menand, Louis. The Metaphysical Club. New York: Farrar, Straus, and Giroux, 2001.

Miller Memories. Miller School: 1927. Miller School of Albemarle Archives.

Miller School of Albemarle Profile for 2016-2017.

Miller School Catalogue. Miller School: 1885. Miller School of Albemarle Archives.

Miller School Catalogue. Miller School: 1901. Miller School of Albemarle Archives.

Miller School Catalogue. Miller School: 1902-03. Miller School of Albemarle Archives.

Miller Manual School No. 1. "Minutes of the Board of Visitors." Miller School. Miller School of Albemarle Archives.

Moore, Jacqueline M. Booker T. Washington, W.E.B. Du Bois, and the Struggle for Racial Uplift. Wilmington: Scholarly Resources, 2003.

Morton, Oren F. A History of Monroe County West Virginia. Dayton, Virginia: Ruebush-Elkins Co., 1916.

Mosby, Charles Lewis. The Samuel Miller Will Case, Arguments by Counsel for Davidson Brothers on Construction of Twenty-Fifth Clause of Will. Lynchburg: J.P. Bell, Browne \&Co., 1873. 
National Register of Historic Places Registration Form. Samuel Miller House. United States Department of the Interior. National Park Service, section 8.

Nugent, Walter. Progressivism: A Very Short Introduction. New York: Oxford University Press, 2010.

Onions, C. T. ed., The Oxford Dictionary of English Etymology. Oxford, England: Oxford Press, 1991.

"Papers of the Miller School Alumni Association, Charles Vawters Report of 1892," Special Collections Alderman Library, University of Virginia.

Perkins Collaborative Resource Network. "Carl D. Perkins Career and Technical Education Act of 2006 (Perkins IV).” http://cte.ed.gov/legislation/about-perkins-iv (accessed October 25, 2016.

Princeton Online. "History of Waldorf Schools." http://www.princetonol.com/local/waldorf/history.html (accessed October 30, 2002).

Public School Review. "Petersburg, Virginia High School." http://www.publicschoolreview.com/petersburg-high-school-profile/23805 (accessed November 1, 2016).

Rare Virginia Pamphlets, Vol. 4. Mosby, Charles Louis. The Samuel Miller Will Case. In the Supreme Court of Appeals. Argument by Counsel for Davidson Brothers on Construction of the Twenty-fifth Clause of the Will. Lynchburg: Bryant \& Brown, 1873, vii. Special Collections, Alderman Library, University of Virginia.

Rare Virginia Pamphlets, Vol. 86. Miller Memories, Vol. 2. Albemarle County: Miller Manual Labor School, 1927. Special Collections, Alderman Library, University of Virginia.

Rare Virginia Pamphlets, Vol. 86. Miller Memories, Vol. 2. Albemarle County: Miller Manual Labor School, 1927. Special Collections, Alderman Library, University of Virginia.

Rawlins, Mary. The Albemarle of Other Days. Charlottesville: Michie Co., 1925.

Reidenbaugh, Lowell. 27 $7^{\text {th }}$ Virginia Infantry. Lynchburg: H.E. Howard, Inc., 1993.

Richmond Dispatch, August 8, 1878. Clipping found in the Miller School of Albemarle Main Office Safe. Miller School of Albemarle Archives. Retrieved June 25, 2014.

Robertson, Clara H. Keys to the History of Miller School of Albemarle Virginia. Unpublished, Special Collections, Alderman Library, University of Virginia.

Runk, B. F. D. "A Brief History of the Early Years of the Miller Manual Labor School," Magazine of Albemarle County History 31, 1974: 22-50. 
Runkle, John D. The Manual Element in Education. Boston: Rand, Avery \& Co., 1882.

Shanker, Uday. Progressive Education. Ambala City, India: The Indian Publications, 1978.

Silber, Kate. Pestalozzi: The Man and his Work. New York: Schocken, 1960.

"Sketch of the Life and Public Service of Captain Charles E. Vawter." Unpublished, Special Collections, Kelly Library, Emory and Henry College.

Soëtard, Michel. "Johann Heinrich Pestalozzi." Prospects: the quarterly review of comparative education (Paris, UNESCO: International Bureau of Education), vol. XXIV, no. 1/2 (1994): 297-310.

Southern, David W. The Progressive Era and Race: Reaction and Reform, 1900-1917. Wheeling, Illinois: Harlan Davidson, Inc., 2005.

Special Collections Virginia Tech, "Charles E. Vawter Family Collection," http://ead.lib.virginia.edu/vivaxtf/view?docId=vt/viblbv01074.xml (accessed June 18, 2013).

Spivey, Donald. Schooling for the New Slavery: Black Industrial Education, 1868-1915. Westport, CT: Greenwood Press, 1978.

Stallones, Jared R. Conflict and Resolution: Progressive Educators and the Question of Religion. Charlotte: Information Age Publishing, Inc., 2010.

Stevenson, George J. Increase in Excellence: A history of Emory and Henry College. New York: Appleton-Century Crofts, 1963.

Swann v. Charlotte-Mecklenburg Board of Education https://www.oyez.org/cases/1970/281 (accessed November 1, 2016).

Talbot, Edith Armstrong. Samuel Chapman Armstrong: A Biographical Study. New York: Doubleday, Page \& Company, 1904.

Tanner, Laurel N. Dewey's Laboratory School: Lessons for Today. New York: Teachers College, 1997.

Tanner, Robert G. Stonewall in the Valley: Thomas J. "Stonewall” Jackson's Shenandoah Valley Campaign Spring 1862. New York: Doubleday \& Co., 1976.

TED - Ideas Worth Spreading. "Interview with Ken Robinson," https://www.ted.com/speakers/sir_ken_robinson (accessed November 22, 2016). 
The Baylor School, Boarding School Review, http://www.boardingschoolreview.com/school_ov/school_id/304 (accessed July 22, 2013).

The Monroe Guard, "Company D $27^{\text {th }}$ Virginia Infantry Regiment," http://www.stonewallbrigade.com/27D_history.html (accessed June 11, 2013).

Thomas, William B. and Kevin J. Moran. "Reconsidering the Power of the Superintendent in the Progressive Period." American Educational Research Journal (Spring 1992, vol.29, no. 1): $22-50$.

Thompkins, Stonewall. Letter to Charles E. Vawter, 29 December 1888. Archives of the Miller School of Albemarle.

Toppin, Edgar and Edwards, Lucious. Loyal Sons and Daughters: Virginia State University 1882 to 1992. Norfolk: Pictorial Heritage Pub. Co., 1992.

Tyack, David B. The One Best System: A History of American Urban Education. Cambridge: Harvard University Press, 1974.

Tyack, David and Larry Cuban. Tinkering Towards Utopia: A Century of Public School Reform. Cambridge: Harvard University Press, 1995.

Unnamed author. "The Miller Manual Labor School of Albemarle, VA.," Scientific American, Vol. LV. No. 24. New York: 1886. Miller School of Albemarle Archives.

U.S. Department of Education, "The Carl D. Perkins Vocational and Technical Education Act, Public Law 105-332," http://www2.ed.gov/offices/OVAE/CTE/perkins.html (accessed October 25, 2016).

Vawter and Longley Literary Societies. Blue Ridge Blast 1905, Vol. 1. Roanoke: Stone Printing Co., 1905. Miller School of Albemarle Archives.

Vawter, Charles E. "Annual Report of the Miller Manual Labor School.” 1891. Miller School of Albemarle Archives.

"Correspondence with Regard to the Civil and Mechanical Department at the University of Virginia." Miller School of Albemarle Archives.

Letter to Stonewall Thompkins, 10 December 1888. Miller School of Albemarle Archives.

"Should the Constitutional Convention Require the Legislature to Pay the Certificates Held by the Schools and Colleges Under the Act of February 23, 1892?" Miller School of Albemarle Archives. 
"The Promotion and Encouragement of Manufactures, the Mechanic and Useful Arts." Speech delivered before the Virginia Mechanic's Institute, Richmond, VA, May 1889.

Miller School of Albemarle Archives.

Van DeBurg, William L. New Day in Babylon: The Black Power Movement and American Culture, 1965-1975. Chicago: The University of Chicago Press, 1992.

Vejnar, Robert J. Archivist Emory and Henry College. E-mail communication with the author, May 13, 2013.

Virginia Normal and Collegiate Institute. "Minutes of the Board of Visitors." Special Collections, Lindsay-Montague Hall, Virginia State University.

Wallenstein, Peter. Virginia Tech: Land Grant University, 1872-1997. Blacksburg: Pocahontas Press, 1997.

Washington, Booker T. Working With The Hands: Being a Sequel to "Up From Slavery" Covering the Author's Experiences in Industrial Education at Tuskegee. New York: Doubleday, Page \& Company, 1904.

Watkins, William H. The White Architects of Black Education: Ideology and Power in America, 1865-1954. New York: Teachers College Press, 2001.

Whitehead, Alfred North. Science and the Modern World. New York: Macmillan, 1925.

Why Waldorf Works. "What is Waldorf Education." http://www.whywaldorfworks.org/02_W Education/index.asp (accessed December 17, 2012).

Wikipedia.org, "Trends in International Mathematics and Science Study," https://en.wikipedia.org/wiki/Trends_in_International_Mathematics_and_Science_Study (accessed November 22, 2016).

Works Progress Administration Writers Program. Jefferson's Albemarle: A guide to Albemarle County and the City of Charlottesville Virginia. Washington, DC: Works Progress Administration, 1941.

Francis E. M.I.T. in Perspective: A Pictorial History of the Massachusetts Institute of Technology. Boston: Little, Brown and Co.:1975.

Yancy, Rosa F. Lynchburg and Its Neighbors. Lynchburg: Warwick House, 1997. 